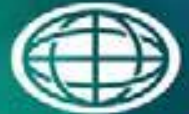

Savannah River

National Laboratory "

OPERATEO BY SAVANAAR RIVER NUCLEAR SOLUTIONS

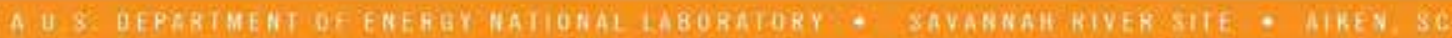

LIQUID-AIR INTERFACE CORROSION TESTING SIMULATING THE ENVIRONMENT OF HANFORD DOUBLE-SHELL TANKS

\author{
J. R. Gray \\ B.L. Garcia-Diaz \\ T. H. Murphy \\ K. R. Hicks
}

December 2013

SRNL-STI-2013-00743, Revision 0 
SRNL-STI-2013-00743

Revision 0

\section{DISCLAIMER}

This work was prepared under an agreement with and funded by the U.S. Government. Neither the U.S. Government or its employees, nor any of its contractors, subcontractors or their employees, makes any express or implied:

1. warranty or assumes any legal liability for the accuracy, completeness, or for the use or results of such use of any information, product, or process disclosed; or

2. representation that such use or results of such use would not infringe privately owned rights; or

3. endorsement or recommendation of any specifically identified commercial product, process, or service.

Any views and opinions of authors expressed in this work do not necessarily state or reflect those of the United States Government, or its contractors, or subcontractors.

\section{Printed in the United States of America \\ Prepared for U.S. Department of Energy}


Keywords: Liquid Air Interface

Corrosion, Ammonia, Hanford Waste

Tanks

Retention: Permanent

\title{
LIQUID-AIR INTERFACE CORROSION TESTING SIMULATING THE ENVIRONMENT OF HANFORD DOUBLE-SHELL TANKS
}

\author{
J. R. Gray \\ B.L. Garcia-Diaz \\ T. H. Murphy \\ K. R. Hicks
}

December 2013

Prepared for the U.S. Department of Energy under contract number DE-AC09-08SR22470.

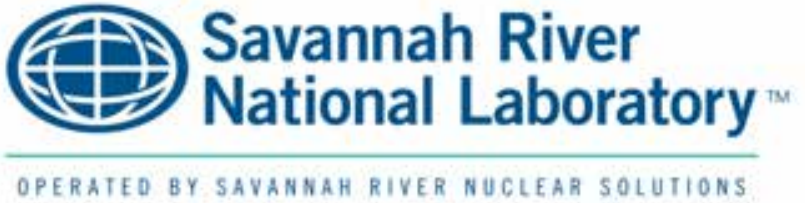




\section{REVIEWS AND APPROVALS}

\section{AUTHORS:}

J.R. Gray, Materials Science and Technology

Date

B.L. Garcia-Diaz, Materials Science and Technology

Date

T.H. Murphy, Materials Science and Technology

Date

K.R. Hicks, Materials Science and Technology

Date

\section{TECHNICAL REVIEW:}

R. E. Fuentes, Materials Science and Technology

Date

\section{APPROVALS:}

K .E. Zeigler, Manager, Savannah River National Laboratory

Date

K. D. Boomer, Program Manager, Washington River Protection Solutions

Date

J. L. Castleberry, Project Manager, Double Shell/Single Shell Tank Integrity Projects

Date Washington River Protection Solutions 


\section{EXECUTIVE SUMMARY}

Coupon tests on A537 carbon steel materials were conducted to evaluate the Liquid-Air Interface (LAI) corrosion susceptibility in a series of solutions designed to simulate conditions in the radioactive waste tanks located at the Hanford Nuclear Facility. The new stress corrosion cracking requirements and the impact of ammonia on LAI corrosion were the primary focus.

The minimum $\mathrm{R}$ value (i.e., molar ratio of nitrite to nitrate) of 0.15 specified by the new stress corrosion cracking requirements was found to be insufficient to prevent pitting corrosion at the LAI. The $\mathrm{pH}$ of the test solutions was 10 , which was actually less than the required $\mathrm{pH} 11$ defined by the new requirements. These tests examined the effect of the variation of the $\mathrm{pH}$ due to hydroxide depletion at the liquid air interface. The pits from the current testing ranged from 0.001 to 0.008 inch in solutions with nitrate concentrations of $0.4 \mathrm{M}$ and $2.0 \mathrm{M}$. The pitting and general attack that occurred progressed over the fourmonths. No significant pitting was observed, however, for a solution with a nitrate concentration of 4.5 M.

The pitting depths observed in these partial immersion tests in unevaporated condensates ranged from 0.001 to 0.005 inch after 4 months. The deeper pits were in simulants with low R values. Simulants with $\mathrm{R}$ values of approximately 0.6 to 0.8 appeared to significantly reduce the degree of attack.

Although, the ammonia did not completely eliminate attack at the LAI, the amount of corrosion in an extremely corrosive solution was significantly reduced. Only light general attack $(<1$ mil) occurred on the coupon in the vicinity of the LAI. The concentration of ammonia (i.e., $50 \mathrm{ppm}$ or $500 \mathrm{ppm}$ ) did not have a strong effect.

Key results and conclusions from this study are as follows:

1. In Solutions \#1, \#2, and \#3, the most aggressive attack occurred at the most dilute solution condition (i.e. Solution \#1). The least aggressive condition was the more concentrated solution condition (i.e., Solution \#3).

2. Since the nitrite/nitrate ratio was constant for all three solutions, this suggests that there is a minimum nitrite concentration above which pitting is mitigated for this nitrite/nitrate ratio.

3. For the unevaporated condensates, the most aggressive corrosion attack was clearly seen in AY-101 Segment 3, 0\% evaporated solution, closely followed by SY-102 High Nitrate 0\% evaporated solution. All samples in the other solutions were only mildly attacked in these solutions.

4. The SY-102, High Chloride solution demonstrated the effect of chloride. Higher concentrations of nitrite are required to mitigate pitting for a given nitrate concentration.

5. The presence of ammonia seemed to mitigate corrosion attack; however the effect of concentration does not seem to be particularly significant at concentrations less than $550 \mathrm{ppm}$. 


\section{TABLE OF CONTENTS}

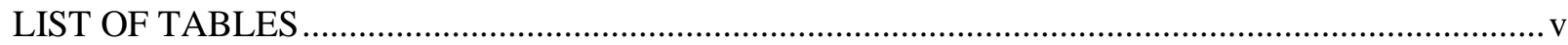

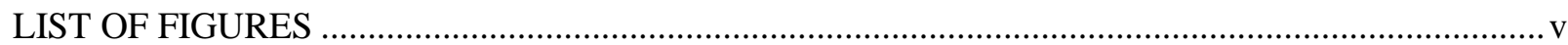

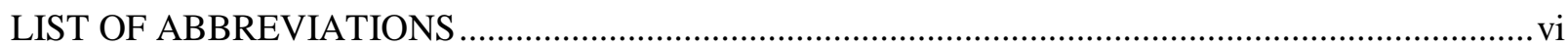

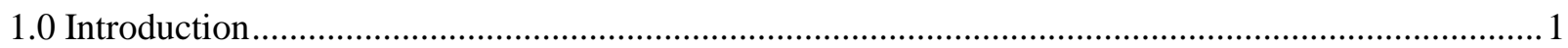

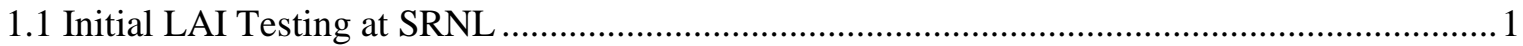

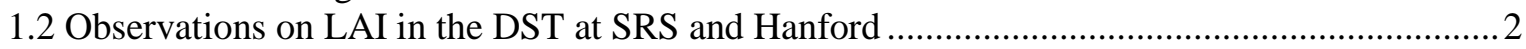

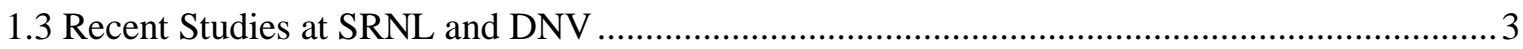

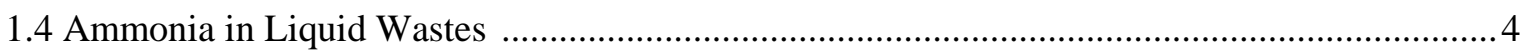

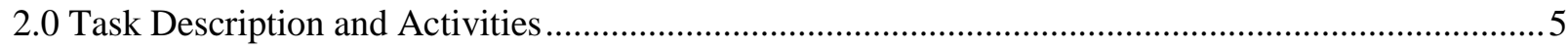

2.1 Effort 1: Long-Term Partial Immersion Coupon Tests..........................................................

2.2 Effort 2: LAI Corrosion in Unevaporated Condensate Simulants ............................................. 6

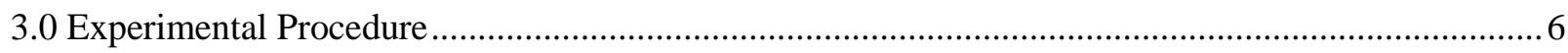

3.1 Coupon testing Without Ammonia Gas ........................................................................... 6

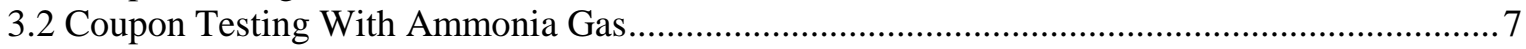

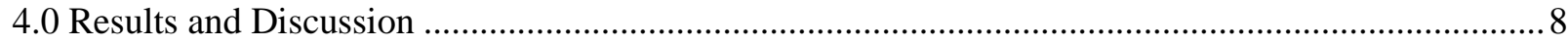

4.1 Coupon Testing for LAI With the New Corrosion Chemistry Limit........................................8

4.2 Coupon Testing in Hanford Simulants Without Ammonia Gas .................................................11

4.3 Coupon Testing in Hanford Simulant SY-102 With Ammonia Gas .......................................16

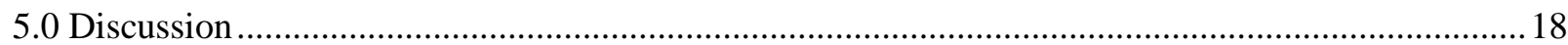

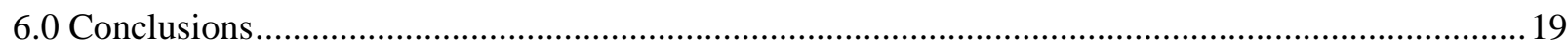

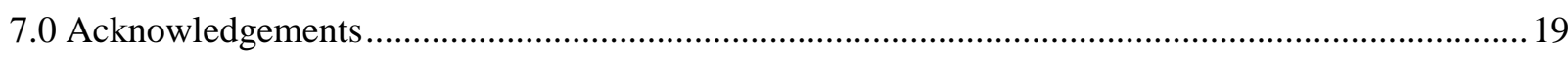

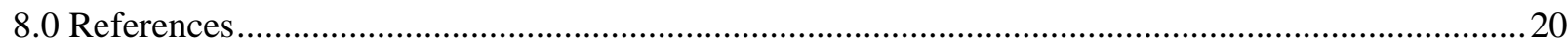

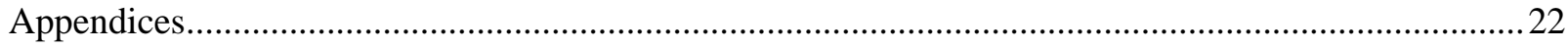

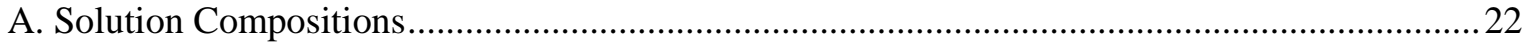

B. New Limits Coupon Test Data................................................................................................ 34

C. Un-evaporated Condensate Coupon Test Data …....................................................................... 51

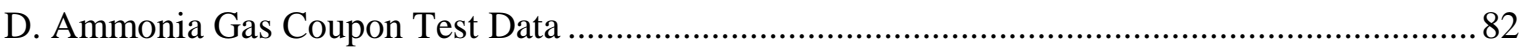




\section{LIST OF TABLES}

Table 1-1. Corrosion Chemistry for Tank 49 During Storage of dilute Water for the First 7 Years......3

Table 1-2. Corrosion Chemistry for Tank AY-101 During Storage of Dilute Wash Water.............3

Table 4-1. Average Weight Losses (g) for A537 Coupons Exposed to Hanford Simulants at New

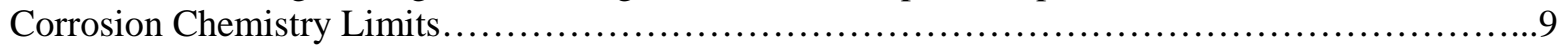

Table 4-2. Summary of localized corrosion observed from liquid-air interface coupon test of new

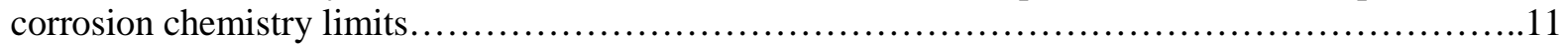

Table 4-3. Average Weight Losses (g) for Coupons Exposed to Hanford Simulants at Unevaporated (0\%) Conditions .12

Table 4-4. Summary of localized corrosion observed from liquid-air interface coupon test for Simulants at Unevaporated ( $0 \%$ ) Conditions. .15

Table 4-5. Average Weight Losses (g) for A537 Coupons Exposed to SY102, High Nitrate, 33\% Evaporated, with Ammonia Cover Gas... .16

Table 4-6. Summary of localized corrosion observed from liquid-air interface coupon test for SY-102, High Nitrate, 33\% Evaporated, with ammonia...

Table 5-1. Summary of localized corrosion observed with liquid-air interface coupon test from previous studies. All tests performed at $40{ }^{\circ} \mathrm{C}$.

\section{LIST OF FIGURES}

Figure 3-1. Experimental Setup for Performance of LAI Tests for Solutions \# 1, \#2, and \#3..........7

Figure 3-2. Coupon test cells for evaluating effect of ammonia gas on carbon steel corrosion over a simulated Hanford waste.

Figure 4-1. Coupons from LAI Corrosion Test at the New Chemistry Limits Prior to Cleaning. Dashed line indicates approximate location of the LAI. ...

Figure 4-2. Coupons from LAI Corrosion Test Exposed to Hanford Simulants AY-101, Segment 3; SY102, High Nitrate; SY-102, High Chloride; at Unevaporated (0\%) Conditions.

Figure 4-3. Coupons from LAI Corrosion Test Exposed to Hanford Simulants AY-101, Segment 8; AN102, High Nitrate; AY-102; at Unevaporated (0\%) Conditions.

Figure 4-4. Coupons from LAI Corrosion SY-102, High Nitrate, 33\% evaporation, with an ammonia cover gas of $50 \mathrm{ppm}$ concentration (1) and $550 \mathrm{ppm}$ concentration (2) prior to cleaning. 


\section{LIST OF ABBREVIATIONS}

$\begin{array}{ll}\text { DST } & \text { Double Shell Tank } \\ \text { LAI } & \text { Liquid-Air Interface } \\ \text { R } & \text { Ratio of molar concentration of nitrite to molar concentration of nitrate } \\ \text { SRNL } & \text { Savannah River National Laboratory } \\ \text { SRS } & \text { Savannah River Site }\end{array}$


SRNL-STI-2013-00743

Revision 0

\subsection{Introduction}

Liquid-Air Interface (LAI) corrosion appears as pitting or localized general attack that occurs on a material at the interface between the solution and vapor space. LAI occurs when the interface remains stagnant for an extended period of time (i.e., several weeks). The location of the attack differs from that which occurs due to differential oxygenation [1] in that the corrosion initiates at the tip of the thin meniscus above the interface, rather than below the LAI. There have been several observations of this phenomenon during laboratory testing, although a clear understanding of the mechanism has not yet been achieved [2-6, 12, 15-17]. The following sections briefly review these observations and some of the mechanisms that have been proposed.

\section{$\underline{1.1 \text { Initial LAI Testing at SRNL }}$}

Observations of LAI corrosion were first reported by Riechman while performing partial immersion coupon tests on A537 carbon steel in dilute waste simulants (i.e. nitrate concentration $\sim 0.08 \mathrm{M}$ at $40^{\circ} \mathrm{C}$ ) [2]. A pit in the vicinity of the LAI grew to a depth of approximately 10 mils during the 2 month test. A decrease in the solution $\mathrm{pH}$ from 13 to 10 was also observed during the test and attributed to a reaction between the hydroxide and carbon dioxide from the air. Although the mechanism was not understood at the time, two means for mitigation of LAI corrosion were identified: 1) periodic agitation of the solution, and 2) addition of nitrite to the solution [3].

Further testing was performed to look at the effects of temperature, nitrite concentration, and mill scale [4] on the observation of LAI corrosion. The following observations were made:

- LAI corrosion was more apparent at $40{ }^{\circ} \mathrm{C}$, than it was at $65^{\circ} \mathrm{C}$. Vapor space corrosion was more prevalent at $65^{\circ} \mathrm{C}$, that at $40^{\circ} \mathrm{C}$.

- The minimum nitrite concentration required to mitigate LAI corrosion increased with the nitrate concentration.

- Pitting was less apparent on mill scale coupons, however, pits that did initiate were deeper. Mill scale afforded more protection against pit initiation, but once pits initiated the surrounding mill scale was more cathodic to the anodic pit site compared to the case of a uniformly ground and polished surface.

The proposed mechanism for LAI corrosion on the partially immersed coupons was as follows [5]:

1) Water evaporates from the bulk solution and re-condenses on the carbon steel surface and eventually forms a continuous film of water on the steel above the LAI. During coupon tests, a film was observed above the LAI.

2) Ions from the bulk solution migrate into this water film until equilibrium is established. No analysis of the water film was made to measure the quantities of the ions that migrated.

3) Because of the high surface area to volume ratio of the film, the hydroxide ions are depleted rapidly by reaction with $\mathrm{CO}_{2}$ from the air (i.e., 1 or 2 days) [6]. Thus, the $\mathrm{pH}$ of the film was expected to be 9.5 to 9.6 even though the $\mathrm{pH}$ of the bulk solution is in the $\mathrm{pH}$ range of 10-12. Models were developed and used to predict the depletion of hydroxide in the water film. However, no measurements of the $\mathrm{pH}$ of the water film were made. 
4) The steel under the wetted film range is vulnerable to attack by aggressive species such as nitrate and/or chloride. Carbon steel contains numerous sulfide inclusions that provide anodic areas adjacent to the inclusions. Characterization of the pits determined that they had initiated adjacent to manganese sulfide inclusions.

5) After the pit reaches a certain depth, an oxygen concentration cell forms around the pit, and the pit grows rapidly by an autocatalytic mechanism. Tubercles, typical of occluded cells, were observed on most coupons after the four month test.

While this mechanism is plausible, it was incomplete as there was no experimental evidence for the $\mathrm{pH}$ decrease in the film, and an understanding of the mechanism by which nitrite inhibits corrosion was not determined.

\subsection{Observations on LAI in the DST at SRS and Hanford}

Based on experimental results, SRS tanks that handle dilute waste from in-tank cesium/strontium processing or dilute waste from sludge washing were anticipated to be the most vulnerable to LAI corrosion. Periscopic observations of an SRS Double Shell Tank (DST) (i.e., Tank 48 where intank processing was executed) were performed to assess the likelihood of LAI corrosion in an actual tank [7]. The simulated environment for this tank had not produced LAI corrosion on the coupons during the laboratory tests, but had resulted in a significant amount of vapor space corrosion. The tank was examined shortly after (i.e., within a year) it had been exposed to the environment. The tank wall was free of LAI attack as expected and had insignificant attack in the vapor space.

The dilute wash water from the process that was performed in Tank 48 was transferred to Tank 49. The composition of this waste was similar to that of the simulants that produced LAI on coupons in the laboratory (see Table 1-1 for compositions) [8]. The level of this tank remained relatively constant for approximately 10 years (i.e., the level decreased approximately 1 foot due to evaporation). During the first 6 to 7 years of storage, samples indicated that the inhibitor concentrations were at levels below the current corrosion control program limits (see Table 1). Since that time, the waste in this tank has been well inhibited.

SRS performs routine in-service ultrasonic inspections of their DSTs [9]. Part of the extent of inspection is to scan a vertical strip along the primary tank wall in order to detect any LAI attack. If LAI attack is suspected based on this inspection, a horizontal strip in the vicinity of the indication is performed. An ultrasonic examination of Tank 49 was performed in 1995 and a band of pits, with depths of approximately 30-40 mils, was observed just above the historic LAI [9]. It is uncertain when these pits may have initiated, however, they were on the order of the size that were observed during the 4 month laboratory tests. The depth and number of these pits has not increased since 1995 [9]. Presently, the band of pits is immersed in a well inhibited (i.e., greater than $2 \mathrm{M}$ hydroxide) waste.

To date, Tank 49 is the only case where there appears to be a band of pits near a historic LAI. All other tanks that have been within the requirements of the SRS corrosion control program for their service history have shown no evidence of LAI corrosion. 
SRNL-STI-2013-00743

Revision 0

Table 1-1. Corrosion Chemistry for Tank 49 During Storage of Dilute Wash Water for the First 7 Years [8].

\begin{tabular}{|l|c|c|c|l|}
\hline Date & Nitrite $(\mathrm{M})$ & Nitrate $(\mathrm{M})$ & Hydroxide & Comments \\
\hline $12 / 14 / 84$ & $<0.2$ & 0.1700 & 0.6100 & Low nitrite \\
\hline $05 / 15 / 85$ & 0.2900 & 0.3670 & 0.1870 & Low nitrite \\
\hline $06 / 19 / 86$ & 0.4200 & 0.2700 & 0.2790 & Low nitrite \\
\hline $11 / 17 / 86$ & 1.1300 & 1.2000 & 0.2300 & OK \\
\hline $06 / 04 / 87$ & 0.2720 & 0.4040 & 0.4000 & Low nitrite \\
\hline $12 / 01 / 88$ & 0.3600 & 0.7000 & 0.3000 & Low nitrite \\
\hline $11 / 30 / 89$ & 0.3570 & 0.5580 & 0.1500 & Low Nitrite \\
\hline $02 / 12 / 90$ & 0.2790 & 0.4350 & 0.0900 & Low Nitrite \\
\hline $02 / 10 / 91$ & 0.7000 & 0.4500 & 0.4610 & OK \\
\hline
\end{tabular}

At Hanford, only Tank AY-101 has shown evidence of significant attack at the LAI [10]. This tank had a band of pits that were at the historic LAI region between the 320 and 360 inch elevations where the waste level had remained for nearly 17 years of the tank's service history. A review of the service history of this tank indicated one series of additions that are of particular concern. Between the fourth quarter of 1984 and the third quarter of 1986 the predominant additions were a dilute, complexed waste from strontium and cesium processing in B-plant. There were also occasional minor water additions during the years between 1987 and 1997. Table 1-2 shows the corrosion chemistry for the waste as it was measured from two different risers in 1996 [11]. As with the SRS samples, these samples were obtained near the surface. However, it should be noted that samples obtained over 200 inches below the surface had a very similar chemistry to the surface samples that are shown in Table 1-2.

Table 1-2. Corrosion Chemistry for Tank AY-101 During Storage of Dilute Wash Water [11]

\begin{tabular}{|l|c|c|c|c|c|c|}
\hline Date & Riser $^{1}$ & Nitrite (M) & Nitrate (M) & Hydroxide & $\mathrm{pH}$ & Comments \\
\hline $2 / 20 / 96$ & $15 \mathrm{~K}$ & 0.738 & 0.403 & $<0.01$ & 9.77 & Low $\mathrm{pH}$ \\
\hline $2 / 28 / 96$ & $15 \mathrm{~S}$ & 0.687 & 0.381 & $<0.01$ & 9.75 & Low $\mathrm{pH}$ \\
\hline
\end{tabular}

\subsection{Recent Studies at SRNL and DNV}

Interest in LAI and vapor space corrosion was renewed at SRS in the early 2000's [12] due to the evidence of cracks in the vapor space of the some of the older Type II waste tanks [13]. At that time, SRS determined that it had not been demonstrated that the minimum corrosion inhibitor requirements for stress corrosion cracking (SCC) in the supernate were sufficient to inhibit LAI and vapor space corrosion. Tests were performed on A285 and A537 carbon steel in a more concentrated waste simulant (i.e., nitrate concentrations of $1.5 \mathrm{M}$ ) and slightly elevated temperatures (i.e., $50{ }^{\circ} \mathrm{C}$ ) than the previously discussed tests. The nitrite and hydroxide concentrations were $0.45 \mathrm{M}$ and $0.15 \mathrm{M}$, respectively. No attack was observed at the LAI on either polished or mill scale coupons [13]. The results suggest that the combination of mill scale on the surface and/or the presence of the inhibitors in the bulk at the minimum corrosion inhibitor requirements provide sufficient protection at the LAI.

\footnotetext{
${ }^{1}$ Note these risers are now designated as Riser 54 instead of Riser 15K and Riser 62 instead of Riser 15S.
} 
In contrast, solutions that were not inhibited (i.e., nitrate concentrations greater than $5 \mathrm{M}$ with inhibitor concentrations less than $0.1 \mathrm{M}$ nitrite and $0.1 \mathrm{M}$ hydroxide) [12, 14], exhibited significant pitting/general corrosion at the LAI. The latter tests also indicated that SCC could initiate near welds at the LAI if sufficient time is allotted (i.e., 18 months).

LAI corrosion was also observed in testing at DNV in a simulant of the waste in Hanford DST AP-105 [15]. This simulant contained 3.6 M nitrate, $0.27 \mathrm{M}$ nitrite and was at a $\mathrm{pH}$ greater than 13. Based on this data, the inhibitor requirements for LAI corrosion are less than the SRS corrosion requirements for SCC in the supernate. Several different test set-ups and analytical techniques have been used to evaluate the effect of nitrite concentration, ammonia concentration, mill scale and electrochemical potential on the development of LAI [15-17]. The key results were:

- A meniscus in which the mass transfer could limit the replenishment of a local chemistry appeared to be necessary. LAI corrosion cannot be fully simulated and explained by the mechanism of crevice corrosion, although there are similarities between the two forms of corrosion.

- LAI corrosion at a polarized potential ( $0 \mathrm{mV}$ vs. SCE) appears to be primarily due to depletion of nitrite.

- Local pH change due to reactions with $\mathrm{CO}_{2}$ (i.e., as suggested by SRNL) or the presence of an aeration cell alone were insufficient to initiate LAI corrosion in the AP-105 simulant at the OCP. The reactions that influence LAI at OCP are still to be determined.

- Accumulation of nitrate ions at the LAI may create an aggressive environment for corrosion to occur, while changes in the nitrite concentration are negligible.

- Ammonia was found to inhibit LAI corrosion even at $0 \mathrm{mV}$ vs. SCE.

- Mill scale was found to protect against LAI corrosion.

In summary, the study of LAI corrosion has been performed by long-term partial immersion tests or in electrochemical tests where the simulant was adjusted to an equilibrium $\mathrm{pH}$ that simulated the hydroxide depleted meniscus. DNV has also focused on the development of an improved accelerated test technique [16, 17]. The most promising technique utilizes a modified CPP technique on a partially immersed plate specimen ( 1 in by 2 in by 0.25 in). The CPP technique is modified in that a slower scan rate is used $(0.05 \mathrm{mV} / \mathrm{s}$ vs. $0.167 \mathrm{mV} / \mathrm{s})$. Because LAI corrosion is an interfacial phenomenon, the depth of immersion was also considered to be important for the evaluation of LAI corrosion susceptibility and for the development of a robust test technique. Testing determined that consistency between the CPP curves and the observation of LAI corrosion on the sample was achieved if the immersion depth is limited to 0.25 in or less. However, the initial attempts at validating this protocol achieved a mixed result [17]. That is, the sample exhibited some LAI corrosion, but the CPP scan showed negative hysteresis. During FY13, DNV performed more verification tests to determine if further modifications to the technique are necessary.

\subsection{Ammonia in Liquid Wastes}

Ammonia is primarily of interest in the Hanford waste tanks as a flammable gas hazard and a noxious vapor [18]. Ammonia is produced predominantly in the liquid waste through thermal and radiolytically induced reactions between organic complexants and nitrate/nitrite anions. Ammonia concentrations in the headspace have been measured at the source (i.e., tank head space or ventilation stack) more than 1500 times. Slightly more than $70 \%$ of the tank headspaces (127 of 177) have been analyzed for ammonia. The highest ammonia concentrations were observed in the single shell tanks, with the maximum concentration under quiescent conditions being 2500 
ppm in Tank U-103. The highest measured ammonia concentration in a DST was 550 ppm in Tank SY-102.

Ammonia has been demonstrated to be beneficial from the standpoint of vapor space corrosion inhibition [19, 20]. The presence of the ammonia maintains the $\mathrm{pH}$ at alkaline values that inhibit corrosion in the condensates that form thin films on the steel in the vapor phase [21]. However, the presence of other aggressive species from dissolved salts on the wall (e.g., nitrate, chloride, etc.) complicates the evaluation.

The ammonia concentrations selected for the tests with the SY-102 simulant were $50 \mathrm{ppm}$ and $550 \mathrm{ppm}$. The lower concentration level was selected to determine a minimum ammonia concentration for corrosion inhibition. The minimum concentration determined from previous tests was $100 \mathrm{ppm}$ [19]. The higher concentration level was selected to be representative of the maximum ammonia concentration observed in the head space of a DST. Coincidentally, this ammonia concentration was observed in Tank SY-102, one of the tanks from which a simulant was developed for vapor space chemistry modeling [21] and vapor space corrosion testing [22].

For the testing, it was desired to establish equilibrium between the ammonia gas and the dissolved ammonia that would be in the condensate. The two concentrations are related by a Henry's Law constant that is a complex function of ionic strength and temperature [18]. Equilibrium ammonia concentrations were calculated on a spreadsheet provided by WRPS [23]. For example, for the SY-102, High Nitrate, $0 \%$ evaporation simulant, if the ammonia gas in the vapor space is at 550 ppm, the dissolved ammonia in the liquid condensate was calculated to be $0.0132 \mathrm{M}$.

To achieve the desired dissolved ammonia concentrations in test solutions, ammonium nitrate was added to the solution. Once dissolved, the ammonium and ammonia achieve equilibrium as shown by the following equation.

$\mathrm{NH}_{4}^{+}+\mathrm{OH}^{-}+(\mathrm{n}-1) \mathrm{H}_{2} \mathrm{O}(\mathrm{l})=\mathrm{NH}_{3}+\mathrm{nH}_{2} \mathrm{O}(\mathrm{aq})$

The equilibrium is a complex function of temperature, $\mathrm{pH}$, and ionic strength. For example, the $\mathrm{NH}_{3} /\left(\mathrm{NH}_{3}+\mathrm{NH}_{4}{ }^{+}\right)$fraction in water at $\mathrm{pH} 10$ and $40{ }^{\circ} \mathrm{C}$ is 0.94 [24]. This fraction decreases with temperature to 0.85 at a temperature of $25{ }^{\circ} \mathrm{C}$. An increase in the ionic strength (e.g., I=1 M) for the $40{ }^{\circ} \mathrm{C}$ value would result in a decrease in the fraction to 0.92 . Based on the $\mathrm{pH}$ and test temperature, and solution compositions, the External Panel for Optimization of Chemistry recommended that the $\mathrm{NH}_{3} /\left(\mathrm{NH}_{3}+\mathrm{NH}_{4}{ }^{+}\right)$fraction should be 0.9. For example, for the SY-102, High Nitrate, 33\% evaporation, the dissolved ammonia in the liquid condensate was calculated to be $0.0132 \mathrm{M}$, and therefore, the ammonium nitrate that was added to the solution was $0.0147 \mathrm{M}$.

\subsection{Task Description and Activities}

The following sections contain descriptions of the tasks involved for each of the efforts that SRNL performed.

\subsection{Effort 1: Long-Term Partial Immersion Coupon Tests}

The focus of Effort 1 was on demonstrating whether LAI corrosion occurs in solutions at the boundary of the new corrosion controls for stress corrosion cracking (SCC) [25]. A537 carbon steel was used for the tests. All testing was performed at $40{ }^{\circ} \mathrm{C}$ in an undisturbed solution and was conducted for a 4 month period. The $\mathrm{pH}$ of the solutions was 10 . The coupons were partially immersed to form an LAI. Tests were run in duplicate. During the course of the tests, the level of the solution were monitored. If the level decreased below the initial height due to 
evaporation, make up water was added. At the conclusion of the test, the samples were evaluated for evidence of LAI corrosion. Pit depths and aspect ratio were measured.

\subsection{Effort 2: LAI corrosion in Unevaporated Condensate Simulants}

Carbon dioxide and ammonia from the air react with the liquid in the meniscus above the LAI and the surface of the liquid adjacent to the tank wall in a similar manner to the way these species interact with condensates in the vapor space. The difference between the vapor space test conditions and these conditions [26] is that species from the bulk solution are available to prevent or accelerate LAI corrosion. Un-evaporated condensate simulants, which were used for previous vapor space corrosion tests, were also used to investigate the susceptibility of carbon steel to LAI corrosion in these environments [27]. Tests with ammonia gas in the vapor were conducted to evaluate whether ammonia inhibits LAI corrosion. The same ammonia concentrations, 50 and $550 \mathrm{ppm}$, that were utilized for the vapor space corrosion tests were used in these tests [26].

A537 carbon steel was also used for the tests. All testing were performed at $40{ }^{\circ} \mathrm{C}$ in an undisturbed solution and were conducted for a 4 month period. The coupons were partially immersed to form an LAI. Tests were run in duplicate. During the course of the test, the level and $\mathrm{pH}$ of the solution were monitored. When the liquid level decreased below the initial height due to evaporation, make up water was added. The tests with ammonia were performed in conjunction with the vapor space corrosion tests that were performed [26].

\subsection{Experimental Procedure}

\subsection{Coupon Testing Without Ammonia Gas}

Each LAI test for Effort 1 started with 4 coupons in total. Two samples were pulled from each test after two months and the last two samples were pulled after 4 months. By pulling two samples at a time, duplicate measurements were obtained at each interval.

The tests that were conducted for Effort 2 were performed with polycarbonate plastic bottles, which were modified to allow four samples to be hung at the level such that the samples would be in the LAI zone. The sample bottles were then placed into a convection oven that was controlled at $40^{\circ} \mathrm{C}$ for the duration of the experiments using a thermometer, which was immersed in the open air.

All solutions were made from reagent-grade chemicals acquired from Fisher Scientific. Solutions were made up on hot plates to allow for full dissolution of the chemical species. The chemistry for all the simulants is shown in Appendix A.

Coupons of Alloy A537 were taken from stock acquired previously from Metal Samples and cut into rectangular sections (1” x 2" $\mathrm{x}^{1} / 8$ "). These sections were polished to a 600 grit finish and allowed to air dry for minimum of 1 day prior to the beginning of the exposure tests. The tests for Effort 1 were conducted in custom designed glass cells as shown below in Figure 3-1. Each rig was set for independent direct control of the hotplate via a thermocouple which was placed below the surface of the liquid solution. Each rig also had a drop funnel to allow the solutions to be topped off with deionized water if solution was lost due to evaporation at the slightly elevated temperatures used in the current study, such that the samples were approximately half-way immersed in solution to mimic the LAI effect. 


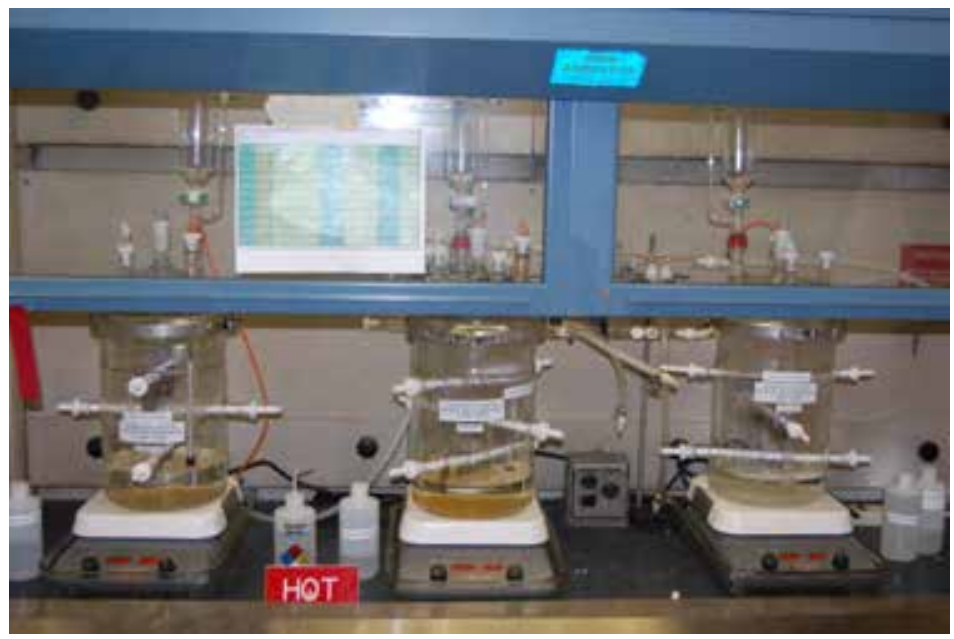

Figure 3-1. Experimental Setup for Performance of LAI Tests for Solutions \# 1, \#2, and \#3.

\subsection{Coupon Testing With Ammonia Gas}

Coupon tests with ammonia gas in the vapor space were set up to evaluate the impact of ammonia gas on corrosion at the LAI. A corrosive Hanford waste chemistry was used, SY102 High Nitrate at 33\% evaporation. The make-up chemistry is shown in Appendix A. All solutions were made from reagent-grade chemicals.

Rectangular A537 carbon steel coupons (1” x 2” x $1 / 8$ ”) were used in the testing with a surface prepared on 600-grit silicon carbide paper. Samples were weighed on a calibrated balance prior to testing. The tests were conducted for four months with samples removed at one-month intervals. Two samples were removed at each time interval for each solution. After removal, the samples were rinsed with distilled water and dried in air, then wrapped in protective tissue and placed within a desiccator. At the conclusion of testing, the samples were photographed and then cleaned using Clark's solution. The coupons were weighed again for calculating total weight loss and a general corrosion rate. Coupons were photographed again for documenting the corrosion morphology.

The test cells that were used are shown in Figure 3-2. Each test cell consisted of a thermocouple controlled hotplate set to $40^{\circ} \mathrm{C}$ and a test solution volume of approximately 1.5L. The coupons were suspended on glass sample holders attached through a $3 / 16$ ” hole drilled in the sample. Ammonia was procured mixed to the desired concentrations of 50 and $550 \mathrm{ppm}$ in air. The gas feeds were then routed through electronic flow meters (Sierra Instruments) which were set to bleed in the cover gas at $5 \mathrm{scc} /$ minute. The gas lines were fed into bubblers which were filled with the same solution as was present in the test cells in order to humidify the gas prior to entering the test cell vapor space. Gas was fed on a constant basis over the four month test duration. 


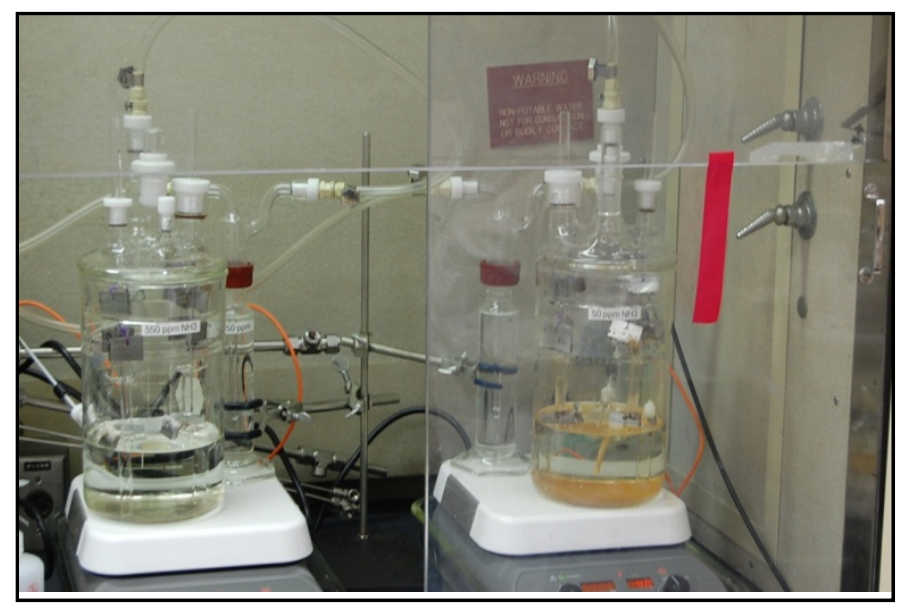

Figure 3-2. Coupon test cells for evaluating effect of ammonia gas on carbon steel corrosion over a simulated Hanford waste.

\subsection{Results and Discussion}

Experimental irregularities occurred during the long term partial immersion coupon tests. Some of the measured attack may be associated with the initial storage after test in which the coupons were not completely dry. The pictures of these coupons (Appendix B, C, and D) show remnants of the paper towels that they were stored in sticking to the coupon surface. Additionally, some of the coupons were mounted in solution so that they became tilted and the top edge was not always parallel to the liquid surface. Although not ideal, the results from the tests do show important trends that may be used to evaluate the susceptibility of carbon steel to LAI attack in these Hanford simulants.

\subsection{Coupon Testing for LAI with the New Corrosion Chemistry Limits}

The ratio of the nitrite concentration to the nitrate concentration is known as the $\mathrm{R}$ value. The solutions for this coupon test were at the new minimum $\mathrm{R}$ value of 0.15 , which is part of the new chemistry limits for stress corrosion cracking mitigation. [Note: New chemistry limits specify a $\mathrm{pH}$ of 11. These tests were performed at $\mathrm{pH} 10$ to simulate the effect of hydroxide depletion at the LAI]. The three test solutions differed in nitrate concentration, 0.4, 2.0 and 4.5M. The solutions did not contain ammonium nitrate nor was ammonia gas used during the test. The complete solution chemistries (i.e., VAS/LAI \#1, VAS/LAI \#2, and VAS/LAI \#3) are given in Appendix A.

The carbon steel coupons experienced varying degrees of attack depending on the nitrate concentration. A first measure of the degree of corrosion can be seen in the weight loss data. Average corrosion losses are given in Table 4-1 for each solution and each month of exposure. The table ranks the simulants in order from the most aggressive to the least aggressive. For all three solutions, the weight loss results indicated that the weight loss increased with exposure time. The results also indicate that for a constant value of $\mathrm{R}$, the attack became more aggressive for dilute solutions. This result suggests that a minimum nitrite concentration is required to inhibit corrosion, in addition to the minimum ratio. This result is similar to that observed in testing in dilute nitrate simulants at SRS [22]. 
The worst corroded side after four months exposure for each solution is shown in Figure 4-1 for comparison. Indications of LAI attack were observed at the lower two nitrate concentrations, Solutions 1 and 2, respectively, while no distinct LAI attack was observed at the highest nitrate concentration, Solution 3. For Solutions 1 and 2 the attack primarily initiated near the LAI and appeared to wick up into the vapor space region. The solutions can be ranked in order of most aggressive as $1>2>3$. The complete set of before- and after-cleaning photographs for each coupon are shown Appendix B along with the coupon weight data (before testing, after testing and loss), pit depth measurements and qualitative assessments of the degree of corrosion.

\section{Table 4-1 Average Weight Losses (g) for A537 Coupons Exposed to Hanford Simulants at New Corrosion Chemistry Limits}

\begin{tabular}{|c|c|c|c|c|}
\hline \multirow{2}{*}{ Solution } & \multirow{2}{*}{$\mathbf{N O}_{3}{ }^{-} \mathbf{( M )}$} & \multirow{2}{*}{$\mathbf{N O}_{2}^{-} \mathbf{( M )}$} & \multicolumn{2}{|c|}{ Months Exposure } \\
\cline { 4 - 5 } & & & $\mathbf{2}$ & $\mathbf{4}$ \\
\hline$\# 1$ & 0.4 & 0.06 & 0.235 & 0.56 \\
\hline$\# 2$ & 2 & 0.3 & 0.137 & 0.229 \\
\hline$\# 3$ & 4.5 & 0.68 & 0.012 & 0.088 \\
\hline
\end{tabular}

The localized corrosion observations are summarized in Table 4-2 for each sample and monthly exposure. The range of pit depths and depth/diameter ratios, and qualitative assessments are given.

The pitting was found to initiate quickly in these solutions, which had low concentrations of the inhibitor nitrite. The deepest pit observed was approximately 8 mils deep after 4 months of exposure to Solution 1. The depth/diameter ratios showed a range of pit dimensions that were typically broad and shallow, but did not change significantly over the course of the four-month test. In most cases, hemispherical, broad shallow pits appeared to initiate and then, after time, coalesce with neighboring pits to create an area of localized general attack. The pit depths and dimensions did not appear to be a function of the solution chemistry. The exposure, however, did increase the degree of surface area attacked and the depth of this attack, especially for solutions $\# 1$ and \#2. The coupons in Solution \#3 were clearly the least attacked. The ranking, $1>2>3$, which was given above, would be the same based on the localized corrosion assessment. 
2 month

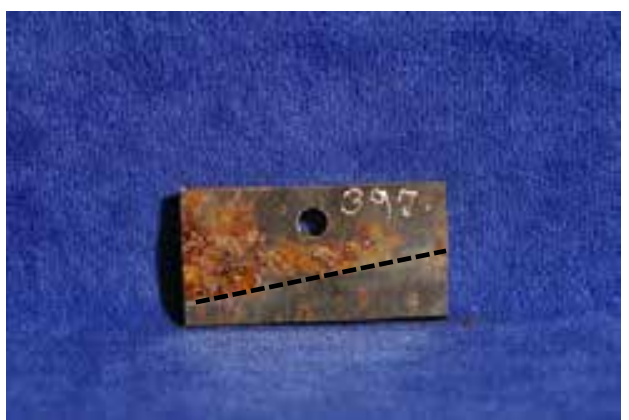

Solution 1

Solution 2
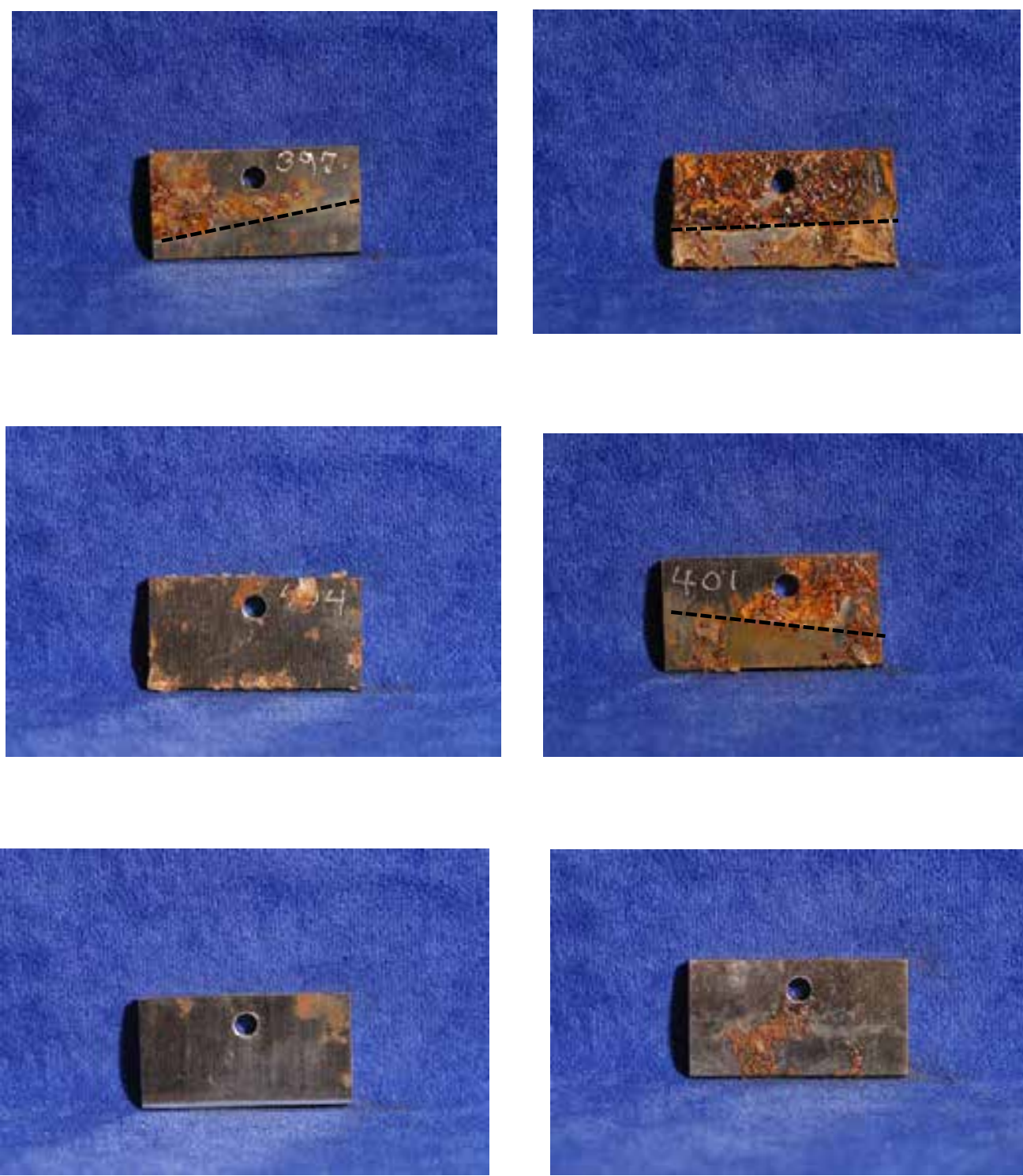

4 month
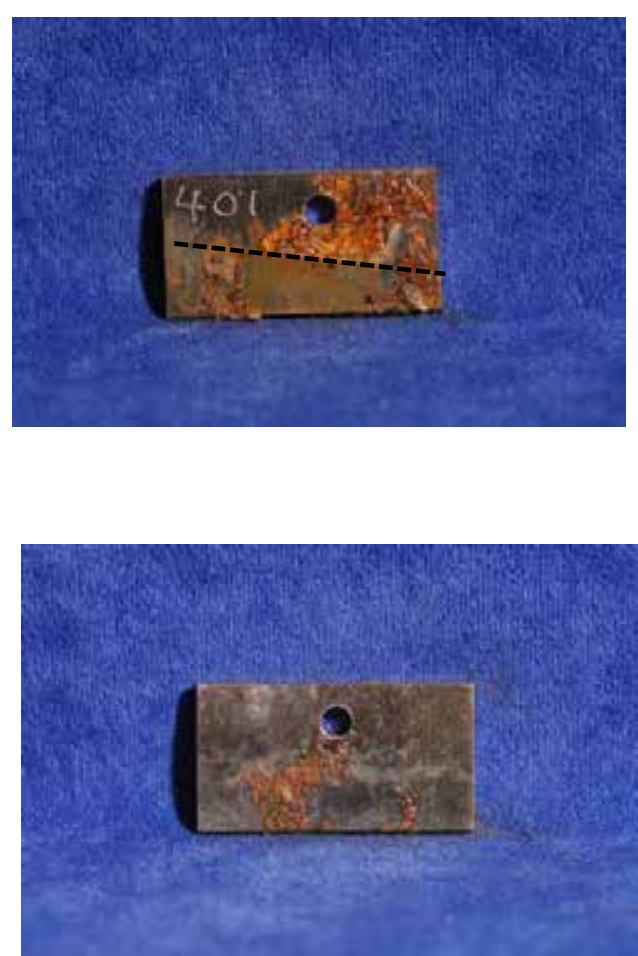

Solution 3

Figure 4-1. Coupons from LAI Corrosion Test at the New Chemistry Limits Prior to Cleaning. Dashed line, where shown, indicates approximate location of the LAI. 
Table 4-2 Summary of localized corrosion observed from liquid-air interface coupon test of new corrosion chemistry limits

\begin{tabular}{|c|c|c|c|c|}
\hline Solution & Month & Depth (mils) & Depth/Diameter & Comment* \\
\hline \multirow[b]{2}{*}{ \#1 } & 2 & $1.5-4.9$ & $0.18-0.38$ & $\begin{array}{l}\text { Distinct LAI corrosion that } \\
\text { wicked up into the vapor space. } \\
\text { GA with some pitting. Limited } \\
\text { attack beneath LAI. }\end{array}$ \\
\hline & 4 & $1.9-7.7$ & $0.15-0.52$ & $\begin{array}{l}\text { Distinct LAI corrosion that } \\
\text { wicked up into the vapor space. } \\
\text { GA with some pitting. Limited } \\
\text { attack beneath LAI. Intensity of } \\
\text { attack is greater than } 2 \text { month. }\end{array}$ \\
\hline \multirow[b]{2}{*}{ \#2 } & 2 & $1.7-2.8$ & 0.19-0.5 & $\begin{array}{l}\text { LAI corrosion not evident. GA } \\
\text { was observed at localized areas } \\
\text { on the whole coupon. }\end{array}$ \\
\hline & 4 & 1.3-3.5 & $0.18-0.42$ & $\begin{array}{l}\text { LAI corrosion was evident, } \\
\text { however the corrosion does not } \\
\text { appear to be only at this region. } \\
\text { GA was observed at localized } \\
\text { areas on the whole coupon. } \\
\text { Intensity of attack was greater } \\
\text { than } 2 \text { month. }\end{array}$ \\
\hline \multirow{2}{*}{ \#3 } & 2 & NA & NA & $\begin{array}{l}\text { No LAI attack observed. Light } \\
\text { GA attack ( }<1 \text { mil) observed in } \\
\text { vapor space region. }\end{array}$ \\
\hline & 4 & $1.1-1.7$ & $0.1-0.23$ & $\begin{array}{l}\text { No LAI attack observed. Light } \\
\text { GA with some pitting observed } \\
\text { both above and below the LAI. }\end{array}$ \\
\hline
\end{tabular}

* GA is general attack and number indicates depth, SGA is general attack over a large percentage of coupon

\subsection{Coupon Testing in Hanford Simulants Without Ammonia Gas}

Un-evaporated condensate simulants, some of which were used for the vapor space corrosion tests, were also used to investigate the susceptibility of carbon steel to LAI corrosion in these environments. The six test solutions ranged in nitrate concentration from $0.004 \mathrm{M}$ to $3.6 \mathrm{M}$ and the $\mathrm{R}$ value ranged from 0.03 to 73 . Both the lowest nitrate concentration and the highest $\mathrm{R}$ value belong to the carbonate based AY-102 simulant. The solutions did not contain ammonium nitrate nor was ammonia gas used during the test. The complete solution chemistries for the unevaporated condensate simulants are given in Appendix A.

The carbon steel coupons experienced varying degrees of attack and showed a strong dependence on the $\mathrm{R}$ value. The most severe LAI attack was observed in the simulants with the two lowest $\mathrm{R}$ values, AY-101 Segment 3 and SY-102 High Nitrate (i.e., R values less than 0.2). The degree of LAI attack was significantly reduced at $\mathrm{R}$ values between approximately 0.6 and 0.8 . These ratios are represented by simulants AY-101, Segment 8, AN-102, and SY-102, High Chloride. Based on the results of AY-101, Segment 8 and AN-102 coupon tests, LAI attack appears to 
decrease significantly at $\mathrm{R}$ values of approximately 0.6. The increase in the degree of attack for the SY-102, High Chloride, even though it has the highest $\mathrm{R}$ value of the three simulants, is likely due to the elevated chloride concentration (i.e. $0.13 \mathrm{M}$, which is approximately an order of magnitude increase over the nominal concentration for SY-102 and approximately 50 to $70 \%$ greater than the chloride concentrations for AN-102 and AY-101, Segment 8). This effect of chloride concentration has been observed previously at SRS in tests involving nitrate based simulants [22]. The extremely high R value for AY-102 resulted in no LAI attack occurring. No conclusions on the effect of absolute nitrite concentration were determined from these tests.

A first measure of the degree of corrosion can be seen in the weight loss data. Average corrosion losses are given in Table 4-3 for each solution after 2 and 4 months of exposure. The table ranks the simulants in order from the most aggressive to the least aggressive. For the two most aggressive solutions, the weight loss results indicated that the degree of attack increases with exposure time. On the other hand, for the four solutions with higher R values, the degree of attack does not appear to increase significantly with time.

Table 4-3 Average Weight Losses (g) for Coupons Exposed to Hanford Simulants at Unevaporated ( $0 \%$ ) Conditions

\begin{tabular}{|l|c|c|c|c|c|}
\hline \multirow{2}{*}{ Solution } & & & & \multicolumn{2}{c|}{ Months Exposure } \\
\cline { 5 - 6 } & $\mathbf{N O}_{\mathbf{3}}{ }^{-} \mathbf{( M )}$ & $\mathbf{N O}_{\mathbf{2}}{ }^{-} \mathbf{( M )}$ & $\mathbf{R}$ & $\mathbf{2}$ & $\mathbf{4}$ \\
\hline AY-101, Segment 3 & 1.01 & 0.17 & 0.16 & 0.196 & 0.444 \\
\hline SY-102, High Nitrate & 3.64 & 0.097 & 0.03 & 0.152 & 0.289 \\
\hline SY102, High Chloride & 1.74 & 1.43 & 0.82 & 0.019 & 0.034 \\
\hline AY-101, Segment 8 & 1.54 & 0.97 & 0.63 & 0.027 & 0.025 \\
\hline AN-102 & 2.52 & 1.52 & 0.60 & $0.027^{*}$ & 0.007 \\
\hline AY-102 & 0.004 & 0.29 & 73 & $\sim 0$ & 0.005 \\
\hline
\end{tabular}

*Based on appearance of the sample, this weight loss appears questionable

The worst corroded side after two and four month exposure for each solution is shown in Figures 4-2 and 4-3 for comparison. For AY-101 Segment 3 and SY-102, High Nitrate, the attack primarily initiates near the LAI and appears to wick up into the vapor space region. There was also some limited attack beneath the LAI. The solutions can be ranked in order of most aggressive as AY-101, Segment $3 \sim$ SY102, High Nitrate >SY-102, High Chloride AY-101, Segment $8>$ AN-102 > AY-102. The complete set of before- and after-cleaning photographs for each coupon is shown Appendix $\mathrm{C}$ along with the coupon weight data (before testing, after testing and loss), pit depth measurements, and qualitative assessments of the degree of corrosion.

The localized corrosion observations are summarized in Table 4-4 for each simulant for the 2 and 4 month exposures. The range of pit depths and depth/diameter ratios, and qualitative assessments are given. The pitting was found to initiate quickly in these solutions, which had low concentrations of the inhibitor nitrite. The deepest pit observed was approximately 4-5 mils deep after 4 months of exposure to AY-101, Segment 3 and SY-102, High Nitrate. The pit depths did not change significantly between 2 and 4 months. The depth/diameter ratios showed a range of pit dimensions, which were typically broad and shallow, but did not change significantly over the course of the 4 month test. In most cases, hemispherical, broad shallow pits appeared to initiate and then, after time, coalesce with neighboring pits to create an area of localized general attack. The pit depths and dimensions did not appear to be a function of the solution chemistry. The exposure time however, did increase the degree of surface area attacked and the depth of this 
attack, especially for AY-101, Segment 3 and SY-102, High Nitrate. Coupons in simulant AY102 were clearly the least attacked. The ranking, in order of most aggressive as AY-101, Segment $3 \sim$ SY102, High Nitrate $>$ SY-102, High Chloride AY-101, Segment $8>$ AN-102 > AY-102, which was given above, would be the same based on the localized corrosion assessment.

2 month

AY-101,

Segment 3

SY-102,

High

Nitrate
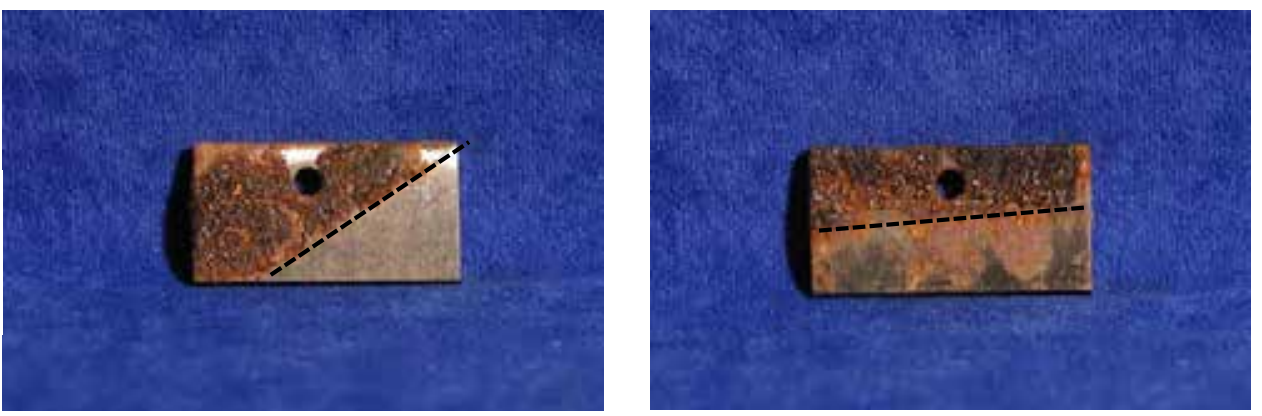

SY-102,

High

Chloride
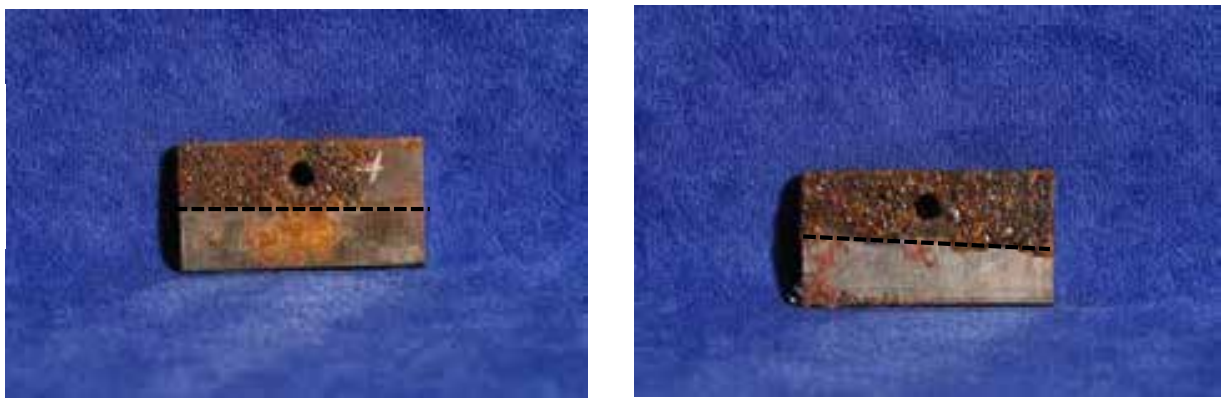

4 month
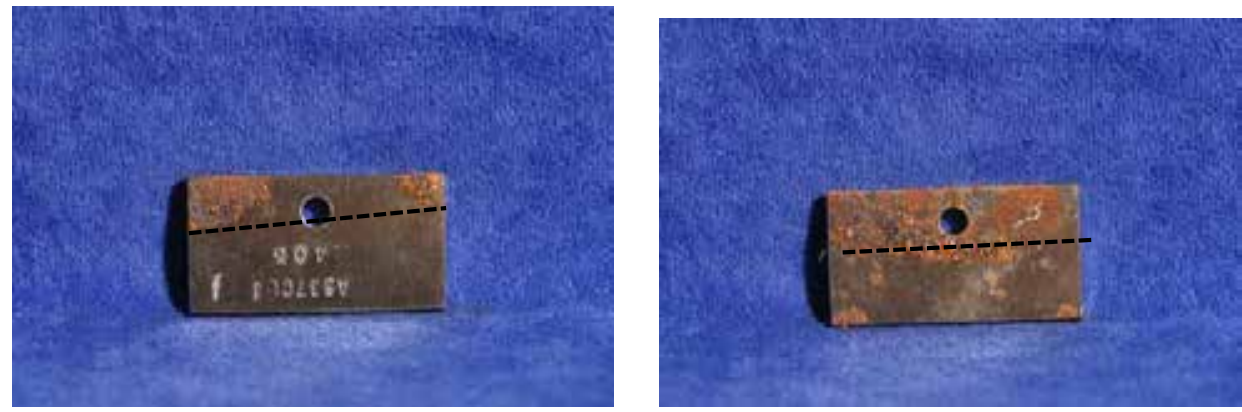

Figure 4-2. Coupons from LAI Corrosion Test Exposed to Hanford Simulants AY-101, Segment 3; SY-102, High Nitrate; SY-102, High Chloride; at Unevaporated (0\%) Conditions. Dashed line indicates approximate location of the LAI. 
2 month

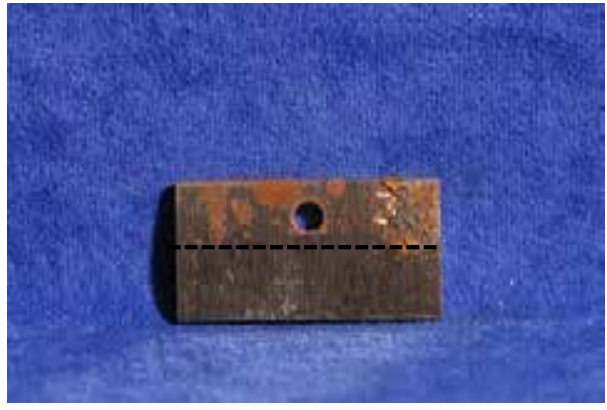

AY-101,

Segment 8

AN-102

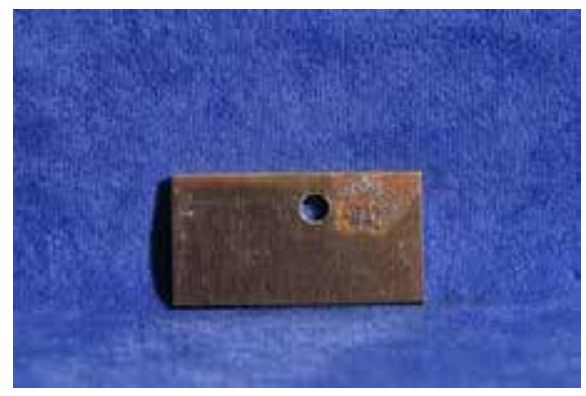

AY-102

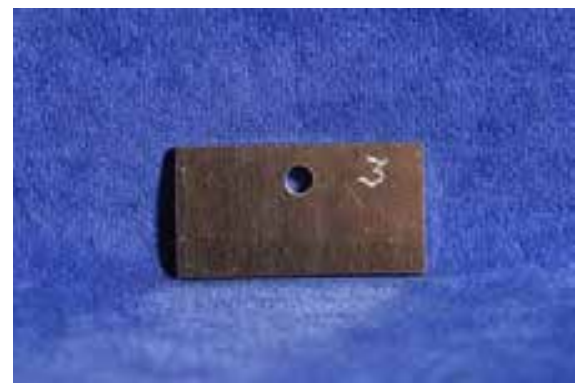

4 month
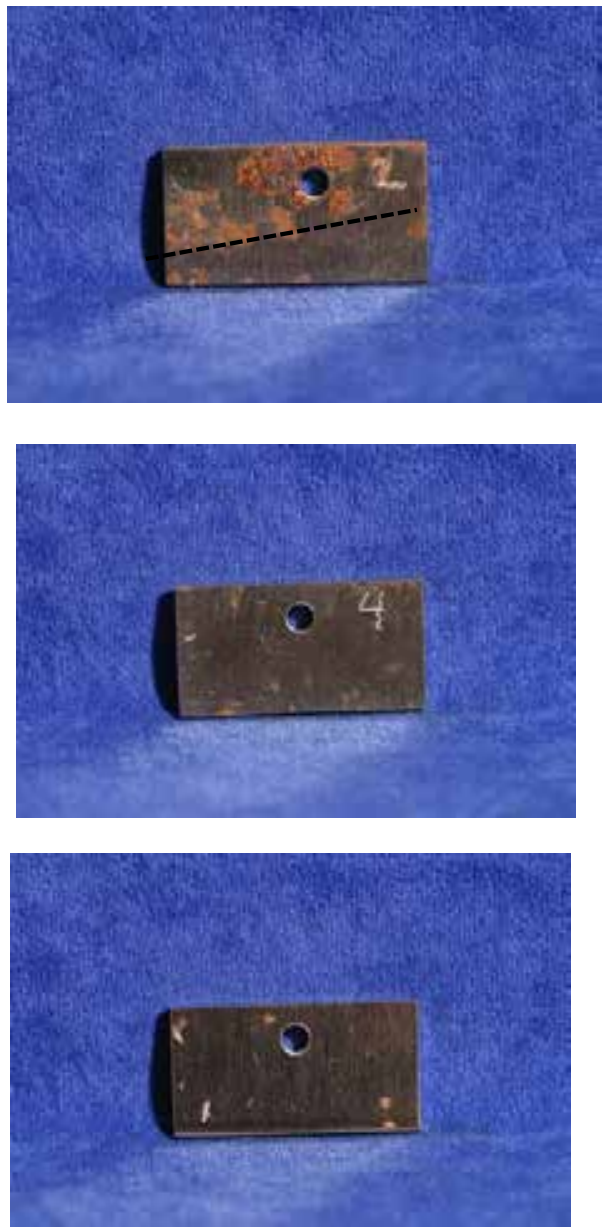

Figure 4-3. Coupons from LAI Corrosion Test Exposed to Hanford Simulants AY-101, Segment 8; AN-102, High Nitrate; AY-102; at Unevaporated (0\%) Conditions. Dashed line indicates approximate location of the LAI. 
Table 4-4 Summary of localized corrosion observed from liquid-air interface coupon test for Simulants at Unevaporated (0\%) Conditions.

\begin{tabular}{|c|c|c|c|c|}
\hline Solution & Month & $\begin{array}{l}\text { Depth } \\
\text { (mils) }\end{array}$ & Depth/Diameter & Comment* \\
\hline \multirow{2}{*}{ AY-101, Segment 3} & 2 & $1.9-4.2$ & $0.22-0.5$ & $\begin{array}{l}\text { Distinct LAI corrosion that } \\
\text { wicked up into the vapor } \\
\text { space. GA with some pitting. } \\
\text { Limited attack beneath LAI. }\end{array}$ \\
\hline & 4 & $1.9-3.4$ & $0.14-0.48$ & $\begin{array}{l}\text { Distinct LAI corrosion that } \\
\text { wicked up into the vapor } \\
\text { space. GA with some pitting. } \\
\text { Limited attack beneath LAI. }\end{array}$ \\
\hline \multirow{2}{*}{ SY-102, High Nitrate } & 2 & $2.1-4.8$ & $0.26-0.45$ & $\begin{array}{l}\text { Distinct LAI corrosion that } \\
\text { wicked up into the vapor } \\
\text { space. GA with some pitting. } \\
\text { Limited attack beneath LAI. }\end{array}$ \\
\hline & 4 & $1.7-4.2$ & $0.25-0.62$ & $\begin{array}{l}\text { Distinct LAI corrosion that } \\
\text { wicked up into the vapor } \\
\text { space. GA with some pitting. } \\
\text { Limited attack beneath LAI. }\end{array}$ \\
\hline \multirow{2}{*}{ SY102, High Chloride } & 2 & $1.2-2.2$ & $0.18-0.43$ & $\begin{array}{l}\text { LAI corrosion evident, } \\
\text { however only on a small area } \\
\text { of the coupon. }\end{array}$ \\
\hline & 4 & $1.1-2.9$ & $0.23-0.59$ & $\begin{array}{l}\text { LAI corrosion evident, } \\
\text { however only on a small area } \\
\text { of the coupon. }\end{array}$ \\
\hline \multirow{2}{*}{ AY-101, Segment 8} & 2 & NA & NA & $\begin{array}{l}\text { Slight indication of LAI } \\
\text { corrosion. Light GA }(<1 \text { mil) } \\
\text { in a couple of locations in the } \\
\text { vapor space region. }\end{array}$ \\
\hline & 4 & NA & NA & $\begin{array}{l}\text { Slight indication of LAI } \\
\text { corrosion. Light GA }(<1 \text { mil }) \\
\text { in a couple of locations in the } \\
\text { vapor space region. }\end{array}$ \\
\hline \multirow{2}{*}{ AN-102 } & 2 & NA & NA & $\begin{array}{l}\text { Light GA ( }<1 \text { mil) in a couple } \\
\text { of locations in the vapor space } \\
\text { region. }\end{array}$ \\
\hline & 4 & NA & NA & $\begin{array}{l}\text { Light GA }(<1 \text { mil) in a couple } \\
\text { of locations in the vapor space } \\
\text { region. }\end{array}$ \\
\hline \multirow{2}{*}{ AY-102 } & 2 & NA & NA & $\begin{array}{l}\text { Surface was essentially clean. } \\
\text { Only a couple of spots of light } \\
\text { GA observed }(<1 \mathrm{mil}) \text {. }\end{array}$ \\
\hline & 4 & NA & NA & $\begin{array}{l}\text { Surface was essentially clean. } \\
\text { Only a couple of spots of light } \\
\text { GA observed ( }<1 \mathrm{mil}) \text {. }\end{array}$ \\
\hline
\end{tabular}

* GA is general attack greater than 1 mil deep NA - Negligible Attack. 


\subsection{Coupon Testing in Hanford Simulant SY-102 With Ammonia Gas}

Over the course of the 4 month test, the corrosion of carbon steel at the LAI was minimal for coupons exposed to SY-102, high nitrate, 33\% evaporated, for both the $50 \mathrm{ppm}$ and $550 \mathrm{ppm}$ ammonia concentrations. The complete solution chemistry is given in Appendix A.

Although the impact of ammonia gas on localized corrosion is of primary interest, the average weight losses also indicate that there was essentially no difference in the resistance of carbon steel for the two ammonia concentrations. In Table 4-5, the average weight loss is shown for each exposure period at the two gas concentrations. These weight losses correspond to less than 1 mpy for both ammonia concentrations. The visual similarity of the coupons at both concentrations is illustrated in Figure 4-3. The degree of corrosion did not increase significantly between the 2 and 4 month time periods. These are the worse sides for each. The pictures of all the coupons before and after cleaning are given in Appendix D.

The localized corrosion observations are summarized in Table 4-6 for each ammonia concentration and the exposure times of 2 and 4 months. Light surface general attack $(<1$ mil deep) in localized regions at or slightly above the LAI was observed. No pitting was noted on the samples during microscopic examination at 200X magnification.

Table 4-5 Average Weight Losses (g) for A537 Coupons Exposed to SY102, High Nitrate, 33\% Evaporated, with Ammonia Cover Gas

\begin{tabular}{|c|c|c|c|c|c|}
\hline $\begin{array}{c}\text { Ammonia } \\
\mathbf{( p p m )}\end{array}$ & $\mathbf{N O}_{3}{ }^{-} \mathbf{( M )}$ & \multirow{2}{*}{$\mathbf{N O}_{2}^{-} \mathbf{( M )}$} & \multirow{2}{*}{} & \multicolumn{2}{|c|}{ Months Exposure } \\
\cline { 5 - 6 } & & & $\mathbf{2}$ & $\mathbf{4}$ \\
\hline 50 & 5.0 & 0.13 & 0.03 & 0.049 & 0.081 \\
\hline 550 & 5.0 & 0.13 & 0.03 & 0.061 & 0.115 \\
\hline
\end{tabular}


2 month
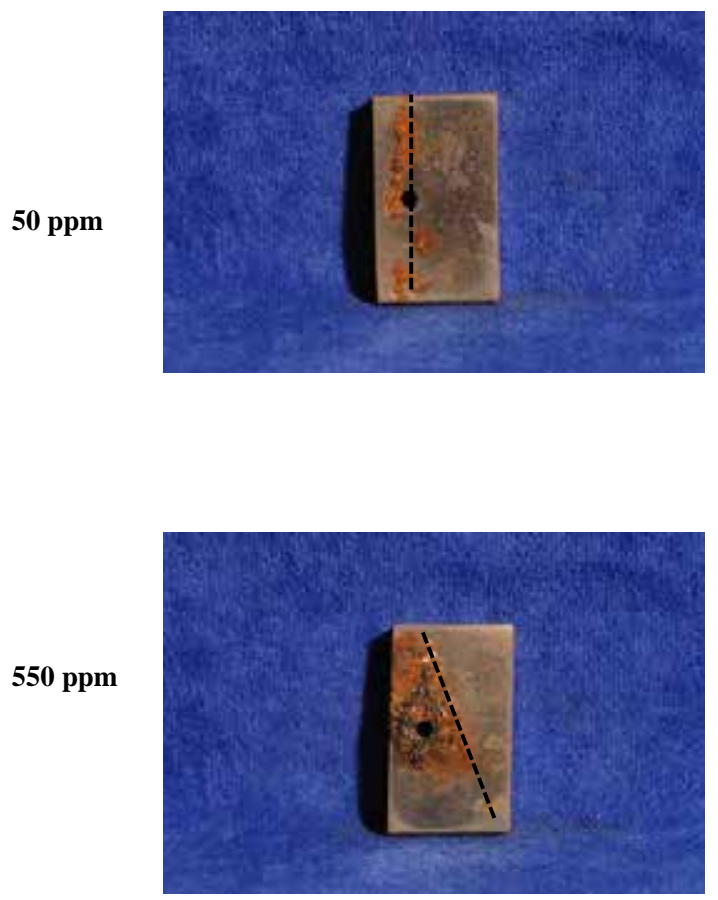

4 month
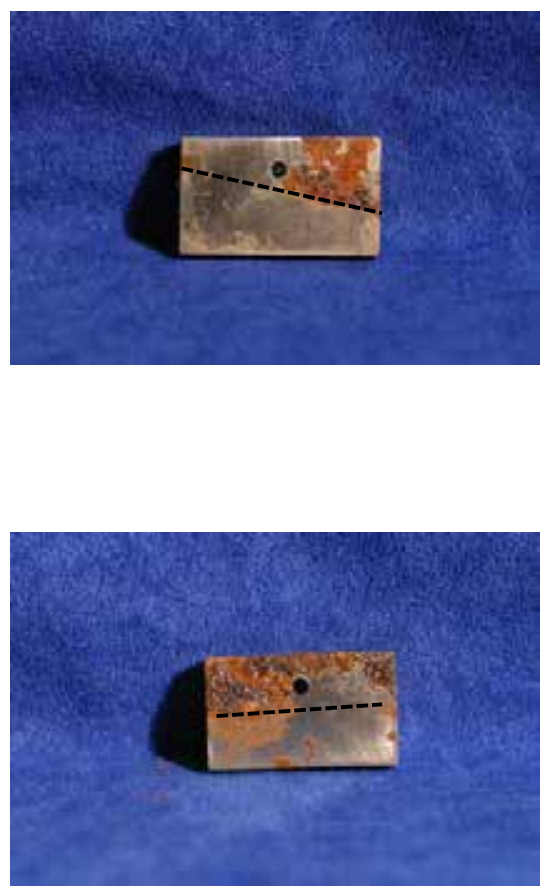

Figure 4-4 Coupons from LAI Corrosion Test of SY-102, High Nitrate, 33\% evaporation, with an ammonia cover gas of $50 \mathrm{ppm}$ concentration (1) and $550 \mathrm{ppm}$ concentration (2) prior to cleaning. Dashed line indicates approximate location of the LAI.

Table 4-6 Summary of localized corrosion observed from liquid-air interface coupon test for SY-102, High Nitrate, 33\% Evaporated, with ammonia

\begin{tabular}{|c|c|c|c|l|}
\hline $\begin{array}{c}\text { Ammonia } \\
\text { Concentration }\end{array}$ & Month & Depth (mils) & Depth/Diameter & Comment* \\
\hline $50 \mathrm{ppm}$ & 2 & NA & NA & $\begin{array}{l}\text { Line of corrosion products at the } \\
\text { LAI. Light GA (<1 mil) attack } \\
\text { occurred. No pitting. }\end{array}$ \\
\cline { 2 - 5 } & 4 & NA & NA & $\begin{array}{l}\text { Light GA (< 1 mil) attack } \\
\text { occurred at and slightly above } \\
\text { the LAI. No pitting. }\end{array}$ \\
\hline $550 \mathrm{ppm}$ & 2 & NA & NA & $\begin{array}{l}\text { Light GA (< 1 mil) attack } \\
\text { occurred at and slightly above } \\
\text { the LAI. No pitting. }\end{array}$ \\
\cline { 2 - 5 } & 4 & NA & NA & $\begin{array}{l}\text { Light GA (< 1 mil) attack } \\
\text { occurred at and slightly above } \\
\text { the LAI. No pitting. }\end{array}$ \\
\hline
\end{tabular}

* GA is general attack and number indicates depth,.

NA - Negligible Attack 


\subsection{Discussion}

This current research evaluated the localized corrosion at the LAI for Hanford DST simulants to assess the new stress corrosion cracking requirements and the impact of ammonia on LAI corrosion. The new minimum $\mathrm{R}$ value of 0.15 was found to be insufficient to prevent pitting corrosion at the LAI. The pitting depths observed in these partial immersion tests fall at the lower end of pit depths measured from previous studies. These depths from SRS testing are summarized in Table 5-1. The pits from the current testing ranged from 0.001 to 0.008 inch in solutions with nitrate concentrations of $0.4 \mathrm{M}$ and $2.0 \mathrm{M}$. Data from previous testing indicated that pit sizes ranged from 0.002 to 0.014 inch (see Table 5-1). The deeper pits or depths of attack are either in inhibitor-free solutions (Example 4) or solutions that were more dilute than those in these current tests (Examples 8 and 9).

The pitting depths observed in these partial immersion tests in unevaporated condensates were also at the lower end of pit depths measured from previous studies. The pits from the current testing ranged from 0.001 to 0.005 inch. The deeper pits are either in inhibitor-free solutions or those with low R values. Examples 3 and 8 in Table 5-1 are in agreement with the present studies which show the benefit of nitrite.

Although, the ammonia did not completely eliminate attack at the LAI, the amount of corrosion in an extremely corrosive solution was significantly reduced. For the SY-102, high nitrate, 33\% evaporated case, the nitrate concentration was $5.0 \mathrm{M}$ and the nitrite to nitrate ratio was 0.026 . At similar conditions in testing performed at SRS without a cover gas of ammonia, the degree of attack was nearly an order of magnitude greater than what was observed for these tests (See Example 4) [12]. The concentration of ammonia in the range of $50 \mathrm{ppm}$ to $550 \mathrm{ppm}$ did not seem to have a significant impact. Previous studies at SRS also indicate that ammonia did not completely eliminate attack at the LAI (see Example 2). This result is in contrast to the elimination of vapor space corrosion by ammonia in the previous SRS tests.

Table 5-1 Summary of localized corrosion observed with liquid-air interface coupon test from previous studies. All tests performed at $40^{\circ} \mathrm{C}$.

\begin{tabular}{|c|c|c|c|c|c|c|c|}
\hline \multirow{2}{*}{ Example } & \multicolumn{2}{|c|}{ Concentration (M) } & \multirow{2}{*}{$\mathbf{p H}^{*}$} & \multirow{2}{*}{$\begin{array}{c}\text { Time } \\
\text { (months) }\end{array}$} & \multirow{2}{*}{$\begin{array}{l}\text { Depth } \\
\text { (mils) }\end{array}$} & \multirow{2}{*}{ Ammonia } & \multirow{2}{*}{ Ref } \\
\hline & Nitrate & Nitrite & & & & & \\
\hline 1 & 0.08 & 0.026 & $12.8 / 9.5$ & 4 & $2-5$ & No & 21 \\
\hline 2 & 0.08 & 0.026 & $12.8 / 9.5$ & 4 & $1-5 * *$ & Yes & 21 \\
\hline 3 & 0.08 & 0.2 & $12.8 / 9.5$ & 4 & None & No & 21 \\
\hline 4 & 5 & 0 & $\mathrm{ND} / \mathrm{ND}$ & 2 & SGA*** & No & 12 \\
\hline 5 & 1.5 & 0.45 & $13+/ \mathrm{ND}$ & 2 & None & No & 12 \\
\hline 6 & 0.08 & 0.04 & $\mathrm{ND} / \mathrm{ND}$ & 2 & 9 & No & 4 \\
\hline 7 & 0.08 & 0.04 & $13 / 10$ & 4 & $<1$ & No & 14 \\
\hline 8 & 0.08 & 0.08 & $13 / 10$ & 4 & 14 & No & 14 \\
\hline 9 & 0.08 & 0.1 & $13 / 10$ & 4 & 14 & No & 14 \\
\hline
\end{tabular}

*Initial pH/Final pH, ND - no data

$* *$ Pits below water line

*** SGA-Severe General Attack > 50 mils 


\subsection{Conclusions}

Key Conclusions from this study are as follows:

1. In Solutions \#1, \#2, and \#3, the most aggressive attack occurred at the most dilute solution condition (i.e. Solution \#1). The least aggressive condition was the more concentrate solution condition (i.e., Solution \#3).

2. Since the nitrite/nitrate ratio was constant for all three solutions, this suggests that there is a minimum nitrite concentration above which pitting is mitigated for this nitrite/nitrate ratio.

3. For the unevaporated condensates, the most aggressive corrosion attack was clearly seen in A-101 Segment 3, 0\% evaporated solution, closely followed by SY-102 High Nitrate $0 \%$ evaporated solution. All samples in the other solutions were only mildly attacked.

4. The SY-102, High Chloride solution demonstrated the effect of chloride. Higher concentrations of nitrite are required to mitigate pitting for a given nitrate concentration.

5. The presence of ammonia seemed to mitigate corrosion attack; however the effect of concentration does not seem to be particularly significant at concentrations less than 550 ppm.

\subsection{Acknowledgements}

The authors wish to acknowledge the assistance of J.I. Mickalonis in completing this task. 
SRNL-STI-2013-00743

Revision 0

\subsection{References}

[1] R. W. Revie and H. H. Uhlig, Corrosion and Corrosion Control: An Introduction to Corrosion Science and Engineering, 4th Ed., John Wiley and Sons, Hoboken, NJ, p. 15, 2008.

[2] A. F. Riechman, “In-Tank Precipitation Corrosion Test Results”, DPST-82-801, September 2 , 1983.

[3] A. F. Riechman, "Integrated Program for Salt Decontamination: Prevention of Waterline Corrosion”, DPST-83-947, October 26, 1983.

[4] A. F. Riechman, "In-Tank Processing: Corrosion Phenomena Due to Storage of Dilute Waste Solutions”, DPST-86-236, January 20, 1986.

[5] J. W. Congdon, “Corrosion Mechanism of Carbon Steel in Washed Precipitate”, DPST-86446, May 19, 1986.

[6] D. T. Hobbs and R. M. Wallace, "Depletion of Hydroxide in Wetted Films Above Alkaline Solutions”, WSRC-TR-90-303, September 7, 1990.

[7] A. F. Riechman, "In-Tank Processing: Inspection Results for Tanks 42H and 48H”, DPST85-471, May 7, 1985.

[8] SRR Database for Corrosion Chemistry Samples Obtained from Tank 49, April 2013.

[9] J. B. Elder, "Tank Inspection NDE Results for Fiscal Year 2005 Including Waste Tanks 28, 42, 44, 45, 46, 47, 49, and 51”, WSRC-TR-2005-00039, September 21, 2005.

[10] C. W. Stewart, et. al., "Independent Review of Tank 241-AY-101 Fitness for Service”, PNNL-14176, February 2003.

[11] R. A. Esch, "Final Report for Tank 241-AY-101, Grab Samples 1AY-96-1 Through 1AY96-10 and 1AY-96-FB”, WHC-SD-WM-178, Rev. 1, 1996.

[12] K. H. Subramanian and P.E. Zapp, "Pitting Corrosion in the Vapor Space and the Liquid Air Interface of High Level Radioactive Waste Tank”, CORROSION 2004, Paper No. 04683, NACE International, Houston, TX, 2004.

[13] B. J. Wiersma and J. B. Elder, "A Structural Impact Assessment of Flaws Detected During Ultrasonic Examination of Tank 15”, SRNS-STI-2008-00028, August 2008.

[14] J. I. Mickalonis, B. L. Garcia-Diaz, and B. J. Wiersma, "Determination of Corrosion Inhibitor Criteria for Type III/IIIA Tanks During Salt Dissolution Operations - Summary Document”, SRNL-STI-2009-00600, October 2009.

[15] H. Cong, et. al, "A Study on the Interfacial Corrosion of Carbon Steel in Dilute Hanford Waste Simulants”, CORROSION 2010, Paper no. 10247, NACE International, Houston, TX, 2010 . 
[16] H. Cong, et. al., “An Electrochemical Study of Liquid Air Interface Corrosion in Dilute Hanford Nuclear Waste”, CORROSION 2011, Paper no. 11212, NACE International, Houston, TX, 2011.

[17] H. Cong, et. al, "Evaluation of Laboratory Screening Techniques for Liquid Air Interface Corrosion in Hanford Waste Simulants", CORROSION 2012, Paper no. 1562, NACE International, Houston, TX, 2012.

[18] R. J. Yarbrough, "Steady-State Flammable Gas Release Rate Calculation and Lower Flammability Level Evaluation for Hanford Tank Waste”, RPP-5926, Rev. 12, September 26, 2012.

[19] R. P. Anantatmula, "DST Pitting Annual Report”, WHC-SD-WM-PRS-016, Rev. 0, September 30, 1996.

[20] J. W. Congdon, "Evaluation of Corrosion inhibitors for Washed precipitate - coupon test results”, DPST-86-721, October 1986.

[21] A.R. Felmy, O. Qafoku, B. Arey, K.D. Boomer, "Chemical Species in the Vapor Phase of Hanford Double-Shell Tanks: Potential Impacts on Waste Tank Corrosion Processes” PNNL19767, September 2010.

[22] E. N. Hoffman, B. L. Garcia-Diaz, T. B. Edwards, "Effect of Chloride and Sulfate Concentration on Probability Based Corrosion Control For Liquid Waste Tanks -Part- IV", SRNL-STI-2011-00479, March 2012.

[23] “RPP-5926 Ammonia Evaluation, v. 1.0”, SVF-1549, Washington River Protection Solutions, Richland, WA, 2008.

[24] R. V. Thurston, et.al, “Aqueous Ammonia Equilibrium”, EPA-600/3-79-091, August, 1979.

[25] L. M. Stock, et. al., "Specifications for the Minimization of the Stress Corrosion Cracking Threat in Double Shell Waste Tanks”, RPP-RPT-47337, Rev. 0, March 2011.

[26] J. R. Gray, B. L. Garcia-Diaz, T. H. Murphy, and K. R. Hicks, "Vapor Space Corrosion Testing Simulating the Environment of Hanford Double Shell Tanks”, SRNL-STI-2013-00739, Rev. 0, December, 2013.

[27] E. N. Hoffman, “Testing Vapor Space and Liquid-Air Interface Corrosion in Simulated Environments of Hanford Double-Shelled Tanks”, SRNL-STI-2011-00494, September, 2011. 
SRNL-STI-2013-00743

Revision 0

APPENDIX A

Solution Compositions 


\section{VAS/LAI SOLUTION 1}

\begin{tabular}{|c|c|c|c|c|}
\hline \multirow{2}{*}{\begin{tabular}{|l|} 
Solution Volume \\
VSC/LAI Solution 1 - SRNL
\end{tabular}} & \multicolumn{2}{|c|}{\begin{tabular}{l|l|l}
2.0000 & $\mathrm{~L}$ \\
\end{tabular}} & & \\
\hline & \multicolumn{4}{|c|}{ CHECK $p H$ before starting electrochemical test, $\mathrm{pH}=10$} \\
\hline & Molecular weight & Experimental Conc (M) & Experimental Mass (g) & Measured Mass \\
\hline $\mathrm{KNO} 3$ & 101.1100 & 0 & 0.0000 & \\
\hline $\mathrm{Na} 2 \mathrm{OAl} 2 \mathrm{O} 33 \mathrm{H} 2 \mathrm{O}$ & 217.9900 & 0 & 0.0000 & \\
\hline $\mathrm{NaBr}$ & 102.8900 & 0 & 0.0000 & \\
\hline $\mathrm{NaCl}$ & 58.4400 & 0.01 & 1.1688 & \\
\hline $\mathrm{NaCrO} 4$ & 161.9700 & 0.0001 & 0.0324 & \\
\hline $\mathrm{NaF}$ & 41.9900 & 0.003 & 0.2519 & \\
\hline NaNO3 & 84.9900 & 0.40 & 67.9920 & \\
\hline NaNO2 & 69.0000 & 0.05 & 6.9000 & \\
\hline $\mathrm{Na} 3 \mathrm{PO} 412 \mathrm{H} 2 \mathrm{O}$ & 380.1200 & 0.0005 & 0.3801 & \\
\hline $\mathrm{Na} 2 \mathrm{SO} 4$ & 142.0400 & 0.005 & 1.4204 & \\
\hline $\mathrm{NaHCO} 3$ & 84.0100 & 0.0250 & 4.2005 & \\
\hline $\mathrm{Na} 2 \mathrm{CO} 3$ & 105.9900 & 0.075 & 15.8985 & \\
\hline $\mathrm{NH} 4 \mathrm{NO} 3$ & 80.0000 & 0.00104 & 0.1671 & \\
\hline
\end{tabular}




\section{VAS/LAI SOLUTION 2}

\begin{tabular}{|c|c|c|c|c|}
\hline \multirow{2}{*}{\begin{tabular}{|l} 
Solution Volume \\
VSC/LAI Solution 2 - SRNL \\
\end{tabular}} & \multicolumn{2}{|c|}{$2.0000 \mathrm{~L}$} & & \\
\hline & \multicolumn{4}{|c|}{$\mathrm{CHECK} \mathrm{pH}$ before starting electrochemical test, $\mathrm{pH}=10$} \\
\hline & Molecular weight & Experimental Conc (M) & Experimental Mass (g) & Measured Mass \\
\hline KNO3 & 101.1100 & 0 & 0.0000 & \\
\hline $\mathrm{Na} 2 \mathrm{OAl} 2 \mathrm{O} 33 \mathrm{H} 2 \mathrm{O}$ & 217.9900 & 0 & 0.0000 & \\
\hline $\mathrm{NaBr}$ & 102.8900 & 0 & 0.0000 & \\
\hline $\mathrm{NaCl}$ & 58.4400 & 0.04 & 4.6752 & \\
\hline $\mathrm{NaCrO} 4$ & 161.9700 & 0.001 & 0.3239 & \\
\hline $\mathrm{NaF}$ & 41.9900 & 0.01 & 0.8398 & \\
\hline NaNO3 & 84.9900 & 2.00 & 339.9600 & \\
\hline NaNO2 & 69.0000 & 0.3 & 41.4000 & \\
\hline $\mathrm{Na} 3 \mathrm{PO} 412 \mathrm{H} 2 \mathrm{O}$ & 380.1200 & 0.01 & 7.6024 & \\
\hline $\mathrm{Na2SO} 4$ & 142.0400 & 0.05 & 14.2040 & \\
\hline $\mathrm{NaHCO} 3$ & 84.0100 & 0.1000 & 16.8020 & \\
\hline $\mathrm{Na} 2 \mathrm{CO} 3$ & 105.9900 & 0.400 & 84.7920 & \\
\hline $\mathrm{NH} 4 \mathrm{NO} 3$ & 80.0000 & 0.000000 & 0.0000 & \\
\hline
\end{tabular}




\section{VAS/LAI SOLUTION 3}

\begin{tabular}{|c|c|c|c|c|}
\hline \multirow{3}{*}{$\begin{array}{l}\text { Solution Volume } \\
\text { VSC/LAI Solution } 3 \text { - SRNL }\end{array}$} & \multicolumn{2}{|c|}{$2.0000[\mathrm{~L}$} & & \\
\hline & \multicolumn{4}{|c|}{$\mathrm{CHECK} \mathrm{pH}$ before starting electrochemical test, $\mathrm{pH}=10$} \\
\hline & Molecular weight & Experimental Conc (M) & Experimental Mass (g) & Measured Mass \\
\hline $\mathrm{KNO} 3$ & 101.1100 & 0 & 0.0000 & \\
\hline $\mathrm{Na} 2 \mathrm{OA} 2 \mathrm{O} 33 \mathrm{H} 2 \mathrm{O}$ & 217.9900 & 0 & 0.0000 & \\
\hline $\mathrm{NaBr}$ & 102.8900 & 0 & 0.0000 & \\
\hline $\mathrm{NaCl}$ & 58.4400 & 0.1 & 11.6880 & \\
\hline $\mathrm{NaCrO} 4$ & 161.9700 & 0.01 & 3.2394 & \\
\hline $\mathrm{NaF}$ & 41.9900 & 0.02 & 1.6796 & \\
\hline $\mathrm{NaNO} 3$ & 84.9900 & 4.50 & 764.9100 & \\
\hline $\mathrm{NaNO} 2$ & 69.0000 & 0.675 & 93.1500 & \\
\hline $\mathrm{Na} 3 \mathrm{PO} 412 \mathrm{H} 2 \mathrm{O}$ & 380.1200 & 0.05 & 38.0120 & \\
\hline $\mathrm{Na2SO} 4$ & 142.0400 & 0.1 & 28.4080 & \\
\hline $\mathrm{NaHCO} 3$ & 84.0100 & 0.1667 & 28.0089 & \\
\hline $\mathrm{Na} 2 \mathrm{CO} 3$ & 105.9900 & 0.833 & 176.6429 & \\
\hline $\mathrm{NH} 4 \mathrm{NO} 3$ & 80.0000 & 0.00000 & 0.0000 & \\
\hline
\end{tabular}


AY101 Segment 3- 0\% Evaporation

\begin{tabular}{|c|c|c|c|c|}
\hline \multirow{3}{*}{$\begin{array}{l}\text { Solution Volume } \\
\text { AY101 segment } 30 \%\end{array}$} & \multicolumn{2}{|c|}{$0.5000 \mathrm{~L}$} & & \\
\hline & \multicolumn{4}{|c|}{ CHECK pH before starting electrochemical test, $\mathrm{pH}=10.15$} \\
\hline & Molecular weight & Experimental Conc (M) & Experimental Mass $(\mathrm{g})$ & Measured Mass \\
\hline $\mathrm{KNO3}$ & 101.1100 & 0 & 0.0000 & \\
\hline $\mathrm{Na} 2 \mathrm{OAl} 2 \mathrm{O} 33 \mathrm{H} 2 \mathrm{O}$ & 217.9900 & 0 & 0.0000 & \\
\hline $\mathrm{NaBr}$ & 102.8900 & 0.0048 & 0.2469 & \\
\hline $\mathrm{NaCl}$ & 58.4400 & 0.013 & 0.3799 & \\
\hline $\mathrm{NaCrO} 4$ & & 0 & 0.0000 & \\
\hline $\mathrm{NaF}$ & 41.9900 & 0.0105 & 0.2204 & \\
\hline $\mathrm{NaNO} 3$ & 84.9900 & 1.01 & 42.9200 & \\
\hline $\mathrm{NaNO} 2$ & 69.0000 & 0.167 & 5.7615 & \\
\hline $\mathrm{Na} 3 \mathrm{PO} 412 \mathrm{H} 2 \mathrm{O}$ & 380.1200 & 0.04 & 7.6024 & \\
\hline $\mathrm{Na} 2 \mathrm{SO} 4$ & 142.0400 & 0.0153 & 1.0866 & \\
\hline $\mathrm{NaHCO} 3$ & 84.0100 & 0.0893 & 3.7510 & \\
\hline $\mathrm{Na} 2 \mathrm{CO} 3$ & 105.9900 & 0.446 & 23.6358 & \\
\hline $\mathrm{NH} 4 \mathrm{NO} 3$ & 80.0000 & 0 & 0.0000 & \\
\hline
\end{tabular}




\section{AY101 Segment 8 - 0\% Evaporation}

\begin{tabular}{|c|c|c|c|c|}
\hline \multirow{3}{*}{\begin{tabular}{|l} 
Solution Volume \\
AY101 segment $80 \%$ \\
\end{tabular}} & \multicolumn{2}{|c|}{$2.0000 \mathrm{~L}$} & & \\
\hline & \multicolumn{4}{|c|}{ CHECK pH before starting electrochemical test, $\mathrm{pH}=10.29$} \\
\hline & \begin{tabular}{|l|} 
Molecular weight \\
\end{tabular} & Experimental Conc (M) & Experimental Mass (g) & Measured Mass \\
\hline $\mathrm{KNO} 3$ & 101.1100 & 0.04 & 8.0888 & \\
\hline $\mathrm{Na} 2 \mathrm{OAl} 2 \mathrm{O} 33 \mathrm{H} 2 \mathrm{O}$ & 217.9900 & 0 & 0.0000 & \\
\hline $\mathrm{NaBr}$ & 102.8900 & 0 & 0.0000 & \\
\hline $\mathrm{NaCl}$ & 58.4400 & 0.086 & 10.0517 & \\
\hline $\mathrm{NaCrO} 4$ & & 0 & 0.0000 & \\
\hline $\mathrm{NaF}$ & 41.9900 & 0.0099 & 0.8314 & \\
\hline $\mathrm{NaNO} 3$ & 84.9900 & 1.54 & 261.7692 & \\
\hline $\mathrm{NaNO} 2$ & 69.0000 & 0.972 & 134.1360 & \\
\hline $\mathrm{Na} 3 \mathrm{PO} 412 \mathrm{H} 2 \mathrm{O}$ & 380.1200 & 0.043 & 32.6903 & \\
\hline $\mathrm{Na} 2 \mathrm{SO} 4$ & 142.0400 & 0.033 & 9.3746 & \\
\hline $\mathrm{NaHCO} 3$ & 84.0100 & 0.0920 & 15.4578 & \\
\hline $\mathrm{Na} 2 \mathrm{CO} 3$ & 105.9900 & 0.828 & 175.5194 & \\
\hline $\mathrm{NH} 4 \mathrm{NO} 3$ & 80.0000 & 0 & 0.0000 & \\
\hline
\end{tabular}




\section{SY102 High Nitrate - 0\% Evaporation}

\begin{tabular}{|c|c|c|c|c|}
\hline \multirow{2}{*}{$\begin{array}{l}\text { Solution Volume } \\
\text { SY102 high nitrate } 0 \%\end{array}$} & \multicolumn{2}{|c|}{$0.7000 \mathrm{~L}$} & & \\
\hline & \multicolumn{4}{|c|}{ CHECK pH before starting electrochemical test, $\mathrm{pH}=10.01$} \\
\hline & Molecular weight & Experimental Conc (M) & Experimental Mass (g) & Measured Mass \\
\hline $\mathrm{KNO} 3$ & 101.1100 & 0.0009 & 0.0637 & \\
\hline $\mathrm{Na} 2 \mathrm{OA} 2 \mathrm{O} 33 \mathrm{H} 2 \mathrm{O}$ & 217.9900 & 0 & 0.0000 & \\
\hline $\mathrm{NaBr}$ & 102.8900 & 0.064 & 4.6095 & \\
\hline $\mathrm{NaCl}$ & 58.4400 & 0.011 & 0.4500 & \\
\hline $\mathrm{NaCrO} 4$ & & 0 & 0.0000 & \\
\hline $\mathrm{NaF}$ & 41.9900 & 0.0026 & 0.0764 & \\
\hline NaNO3 & 84.9900 & 3.6391 & 216.5010 & \\
\hline NaNO2 & 69.0000 & 0.097 & 4.6851 & \\
\hline $\mathrm{Na} 3 \mathrm{PO} 412 \mathrm{H} 2 \mathrm{O}$ & 380.1200 & 0.024 & 6.3860 & \\
\hline $\mathrm{Na} 2 \mathrm{SO} 4$ & 142.0400 & 0.047 & 4.6731 & \\
\hline $\mathrm{NaHCO} 3$ & 84.0100 & 0.0304 & 1.7885 & \\
\hline $\mathrm{Na} 2 \mathrm{CO} 3$ & 105.9900 & 0.265 & 19.6305 & \\
\hline $\mathrm{NH} 4 \mathrm{NO} 3$ & 80.0520 & 0 & 0.0000 & \\
\hline
\end{tabular}




\section{AN102 - 0\% Evaporation}

\begin{tabular}{|c|c|c|c|c|}
\hline \multirow{2}{*}{$\begin{array}{l}\text { Solution Volume } \\
\text { AN102, } 0 \%\end{array}$} & \multicolumn{2}{|c|}{$0.5000 \mathrm{~L}$} & & \\
\hline & \multicolumn{4}{|c|}{ CHECK pH before starting electrochemical test, $\mathrm{pH}=10.41$} \\
\hline & Molecular weight & Experimental Conc (M) & Experimental Mass (g) & Measured Mass \\
\hline KNO3 & 101.1100 & 0.033 & 1.6683 & \\
\hline $\mathrm{Na} 2 \mathrm{OA} 2 \mathrm{O} 33 \mathrm{H} 2 \mathrm{O}$ & 217.9900 & 0 & 0.0000 & \\
\hline $\mathrm{NaBr}$ & 102.8900 & 0.0066 & 0.3395 & \\
\hline $\mathrm{NaCl}$ & 58.4400 & 0.078 & 2.2792 & \\
\hline $\mathrm{NaCrO} 4$ & & 0 & 0.0000 & \\
\hline $\mathrm{NaF}$ & 41.9900 & 0.0025 & 0.0525 & \\
\hline $\mathrm{NaNO} 3$ & 84.9900 & 2.484 & 105.5576 & \\
\hline $\mathrm{NaNO} 2$ & 69.0000 & 1.52 & 52.4400 & \\
\hline $\mathrm{Na} 3 \mathrm{PO} 412 \mathrm{H} 2 \mathrm{O}$ & 380.1200 & 0.05 & 9.5030 & \\
\hline $\mathrm{Na} 2 \mathrm{SO} 4$ & 142.0400 & 0.11 & 7.8122 & \\
\hline $\mathrm{NaHCO} 3$ & 84.0100 & 0.0460 & 1.9322 & \\
\hline $\mathrm{Na} 2 \mathrm{CO} 3$ & 105.9900 & 1.104 & 58.5065 & \\
\hline $\mathrm{NH} 4 \mathrm{NO} 3$ & 80.0000 & 0 & 0.0000 & \\
\hline & Ionic Strength & 8.1121 & & \\
\hline
\end{tabular}




\section{AY102 - 0\% Evaporation}

Solution Volume

AY-102, 0\%

\section{KNO3}

$\mathrm{Na} 2 \mathrm{OAl} 2 \mathrm{O} 33 \mathrm{H} 2 \mathrm{O}$

$\mathrm{NaBr}$

$\mathrm{NaCl}$

$\mathrm{NaCrO} 4$

$\mathrm{NaF}$

$\mathrm{NaNO} 3$

$\mathrm{NaNO} 2$

$\mathrm{Na} 3 \mathrm{PO} 412 \mathrm{H} 2 \mathrm{O}$

$\mathrm{Na} 2 \mathrm{SO} 4$

$\mathrm{NaHCO} 3$

$\mathrm{Na} 2 \mathrm{CO} 3$

$\mathrm{NH} 4 \mathrm{NO} 3$

\section{$0.5000 \mathrm{~L}$}

CHECK $\mathrm{pH}$ before starting electrochemical test, $\mathrm{pH}=10.17$ \begin{tabular}{|l|l|l|l|l|} 
Molecular weight & Experimental Conc (M) & Experimental Mass (g) & Measured Mass \\
\hline
\end{tabular}

\begin{tabular}{|r|r|r|l|}
\hline 101.1100 & 0.004 & 0.2022 & \\
\hline 217.9900 & 0 & 0.0000 & \\
\hline 102.8900 & 0.015 & 0.7717 & \\
\hline & 0.001 & 0.0292 & \\
\hline 48.4400 & 0 & 0.0000 & \\
\hline 64.9900 & 0.001 & 0.0210 & \\
\hline 380.1200 & 0 & 0.0000 & \\
\hline 142.0400 & 2.93 & 101.0850 & \\
\hline 84.0100 & 0.011 & 2.0907 & \\
\hline 105.9900 & 0.008 & 0.5682 & \\
\hline 80.0000 & 0.0330 & 1.3862 & \\
\hline & 0.452 & 23.9537 & \\
\hline
\end{tabular}

217.9900

102.8900

58.4400

41.9900

84.9900

69.0000

380.1200

142.0400

84.0100

105.9900

80.0000 


\section{SY102 High Chloride - 0\% Evaporation}

\begin{tabular}{|c|c|c|c|c|}
\hline \multirow{3}{*}{$\begin{array}{l}\text { Solution Volume } \\
\text { sY102-High Chloride, } 0 \%\end{array}$} & \multicolumn{2}{|c|}{$0.5000 \mathrm{~L}$} & & \\
\hline & \multicolumn{4}{|c|}{ CHECK pH before starting electrochemical test, $\mathrm{pH}=10.27$} \\
\hline & Molecular weight & Experimental Conc (M) & Experimental Mass (g) & Measured Mass \\
\hline $\mathrm{KNO} 3$ & 101.1100 & 0.052 & 2.6289 & \\
\hline $\mathrm{Na} 2 \mathrm{OAl} 2 \mathrm{O} 33 \mathrm{H} 2 \mathrm{O}$ & 217.9900 & 0 & 0.0000 & \\
\hline $\mathrm{NaBr}$ & 102.8900 & 0.0052 & 0.2675 & \\
\hline $\mathrm{NaCl}$ & 58.4400 & 0.13 & 3.7986 & \\
\hline $\mathrm{NaCrO} 4$ & & 0 & 0.0000 & \\
\hline $\mathrm{NaF}$ & 41.9900 & 0.087 & 1.8266 & \\
\hline $\mathrm{NaNO} 3$ & 84.9900 & 1.686 & 71.6466 & \\
\hline $\mathrm{NaNO} 2$ & 69.0000 & 1.43 & 49.3350 & \\
\hline $\mathrm{Na} 3 \mathrm{PO} 412 \mathrm{H} 2 \mathrm{O}$ & 380.1200 & 0.0445 & 8.4577 & \\
\hline $\mathrm{Na} 2 \mathrm{SO} 4$ & 142.0400 & 0.022 & 1.5624 & \\
\hline $\mathrm{NaHCO} 3$ & 84.0100 & 0.0480 & 2.0162 & \\
\hline $\mathrm{Na} 2 \mathrm{CO} 3$ & 105.9900 & 0.772 & 40.9121 & \\
\hline $\mathrm{NH} 4 \mathrm{NO} 3$ & 80.0000 & 0 & 0.0000 & \\
\hline
\end{tabular}


SY102 High Nitrate - 32.81\% Evaporation - 50 ppm $\mathrm{NH}_{3}$

\begin{tabular}{|c|c|c|c|c|}
\hline \multirow{3}{*}{$\begin{array}{l}\text { Solution Volume } \\
\text { SY102 high nitrate } 32.81 \%, 50 \mathrm{ppm}\end{array}$} & \multicolumn{2}{|c|}{$2.0000 \mathrm{~L}$} & & \\
\hline & \multicolumn{4}{|c|}{ CHECK pH before starting electrochemical test, $\mathrm{pH}=10.16$} \\
\hline & Molecular weight & Experimental Conc (M) & Experimental Mass $(\mathrm{g})$ & Measured Mass \\
\hline KNO3 & 101.1100 & 0.0012 & 0.2427 & \\
\hline $\mathrm{Na} 2 \mathrm{OA} 2 \mathrm{O} 33 \mathrm{H} 2 \mathrm{O}$ & 217.9900 & 0 & 0.0000 & \\
\hline $\mathrm{NaBr}$ & 102.8900 & 0.088 & 18.1086 & \\
\hline $\mathrm{NaCl}$ & 58.4400 & 0.015 & 1.7532 & \\
\hline $\mathrm{NaCrO} 4$ & & 0 & 0.0000 & \\
\hline $\mathrm{NaF}$ & 41.9900 & 0.0036 & 0.3023 & \\
\hline $\mathrm{NaNO} 3$ & 84.9900 & 5.02 & 852.8312 & \\
\hline $\mathrm{NaNO} 2$ & 69.0000 & 0.13 & 17.9400 & \\
\hline $\mathrm{Na} 3 \mathrm{PO} 412 \mathrm{H} 2 \mathrm{O}$ & 380.1200 & 0.033 & 25.0879 & \\
\hline $\mathrm{Na} 2 \mathrm{SO} 4$ & 142.0400 & 0.064 & 18.1811 & \\
\hline $\mathrm{NaHCO} 3$ & 84.0100 & 0.0450 & 7.5609 & \\
\hline $\mathrm{Na} 2 \mathrm{CO} 3$ & 105.9900 & 0.360 & 76.3128 & \\
\hline $\mathrm{NH} 4 \mathrm{NO} 3$ & 80.0520 & 0.00156 & 0.2491 & \\
\hline
\end{tabular}


SY102 High Nitrate - 32.81\% Evaporation - $550 \mathrm{ppm} \mathrm{NH}_{3}$

\begin{tabular}{|c|c|c|c|c|}
\hline \multirow{3}{*}{$\begin{array}{l}\text { Solution Volume } \\
\text { SY102 high nitrate } 32.81 \%, 550 \mathrm{ppm}\end{array}$} & 2.0000 & $\mathrm{~L}$ & & \\
\hline & \multicolumn{4}{|c|}{ CHECK $\mathrm{pH}$ before starting electrochemical test, $\mathrm{pH}=10.16$} \\
\hline & Molecular weight & Experimental Conc (M) & Experimental Mass $(\mathrm{g})$ & Measured Mass \\
\hline KNO3 & 101.1100 & 0.0012 & 0.2427 & \\
\hline $\mathrm{Na} 2 \mathrm{OA} 2 \mathrm{O} 33 \mathrm{H} 2 \mathrm{O}$ & 217.9900 & 0 & 0.0000 & \\
\hline $\mathrm{NaBr}$ & 102.8900 & 0.088 & 18.1086 & \\
\hline $\mathrm{NaCl}$ & 58.4400 & 0.015 & 1.7532 & \\
\hline $\mathrm{NaCrO} 4$ & & 0 & 0.0000 & \\
\hline $\mathrm{NaF}$ & 41.9900 & 0.0036 & 0.3023 & \\
\hline $\mathrm{NaNO} 3$ & 84.9900 & 5.00 & 850.1871 & \\
\hline $\mathrm{NaNO} 2$ & 69.0000 & 0.13 & 17.9400 & \\
\hline $\mathrm{Na} 3 \mathrm{PO} 412 \mathrm{H} 2 \mathrm{O}$ & 380.1200 & 0.033 & 25.0879 & \\
\hline $\mathrm{Na2SO4}$ & 142.0400 & 0.064 & 18.1811 & \\
\hline $\mathrm{NaHCO} 3$ & 84.0100 & 0.0450 & 7.5609 & \\
\hline $\mathrm{Na} 2 \mathrm{CO} 3$ & 105.9900 & 0.360 & 76.3128 & \\
\hline $\mathrm{NH} 4 \mathrm{NO} 3$ & 80.0520 & 0.0171 & 2.7396 & \\
\hline
\end{tabular}


SRNL-STI-2013-00743

Revision 0

APPENDIX B

New Limits Coupon Test Data 
Solution 1 - 2 Months

Coupon \# 397
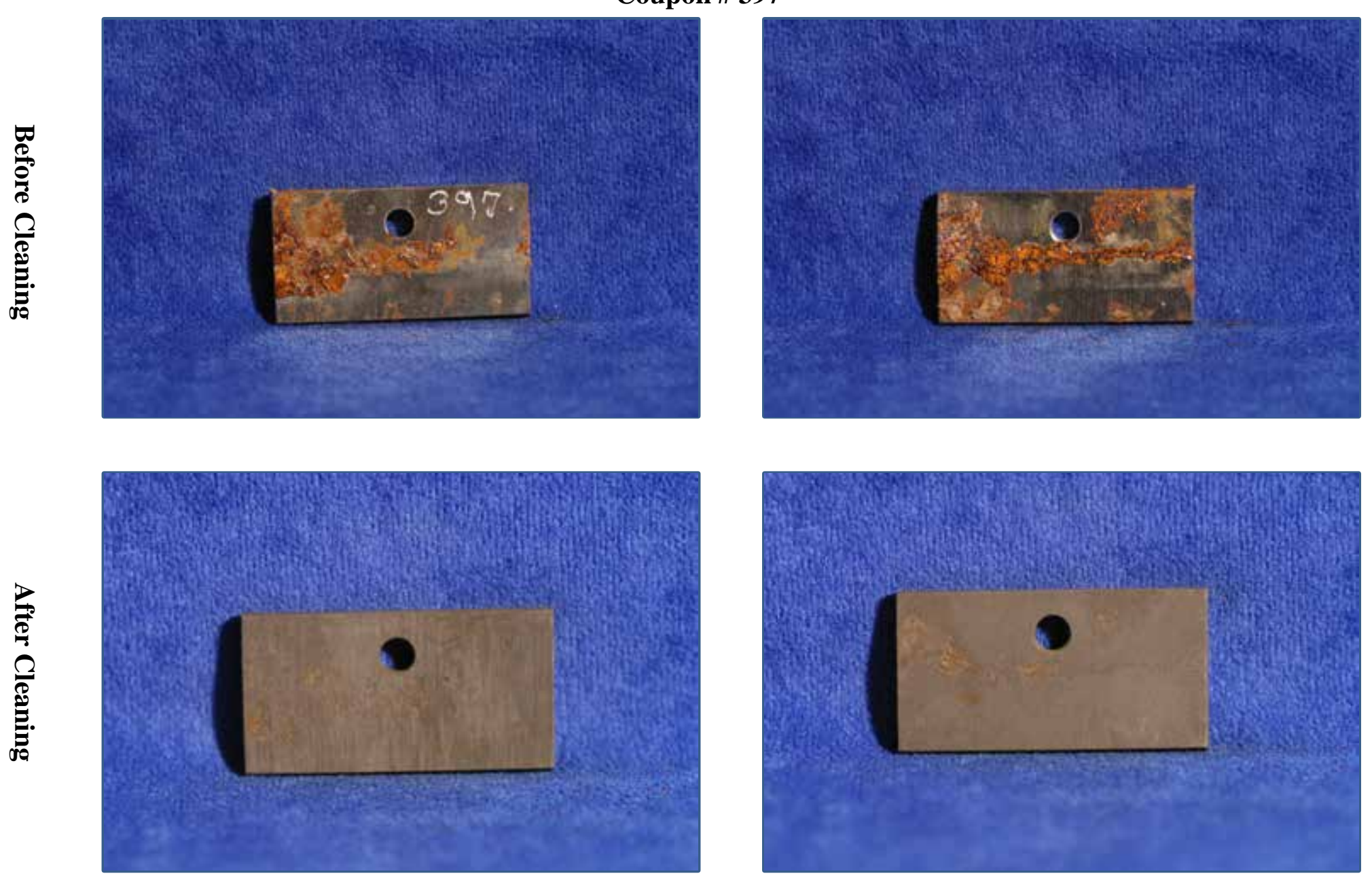
Solution 1 - 2 Months

Coupon \# 397
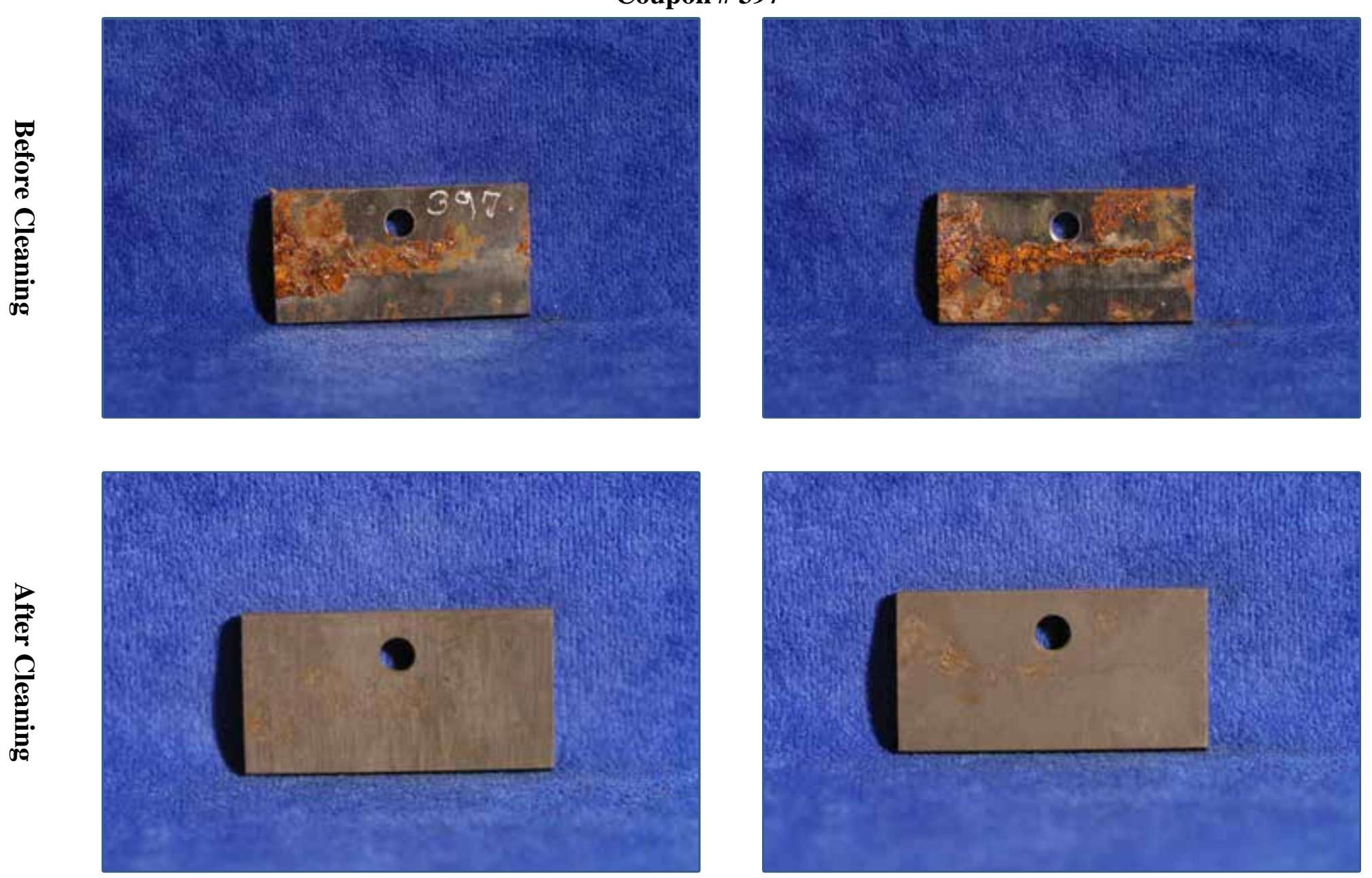
Solution 1 - 2 Months

\section{Coupon \# 398}
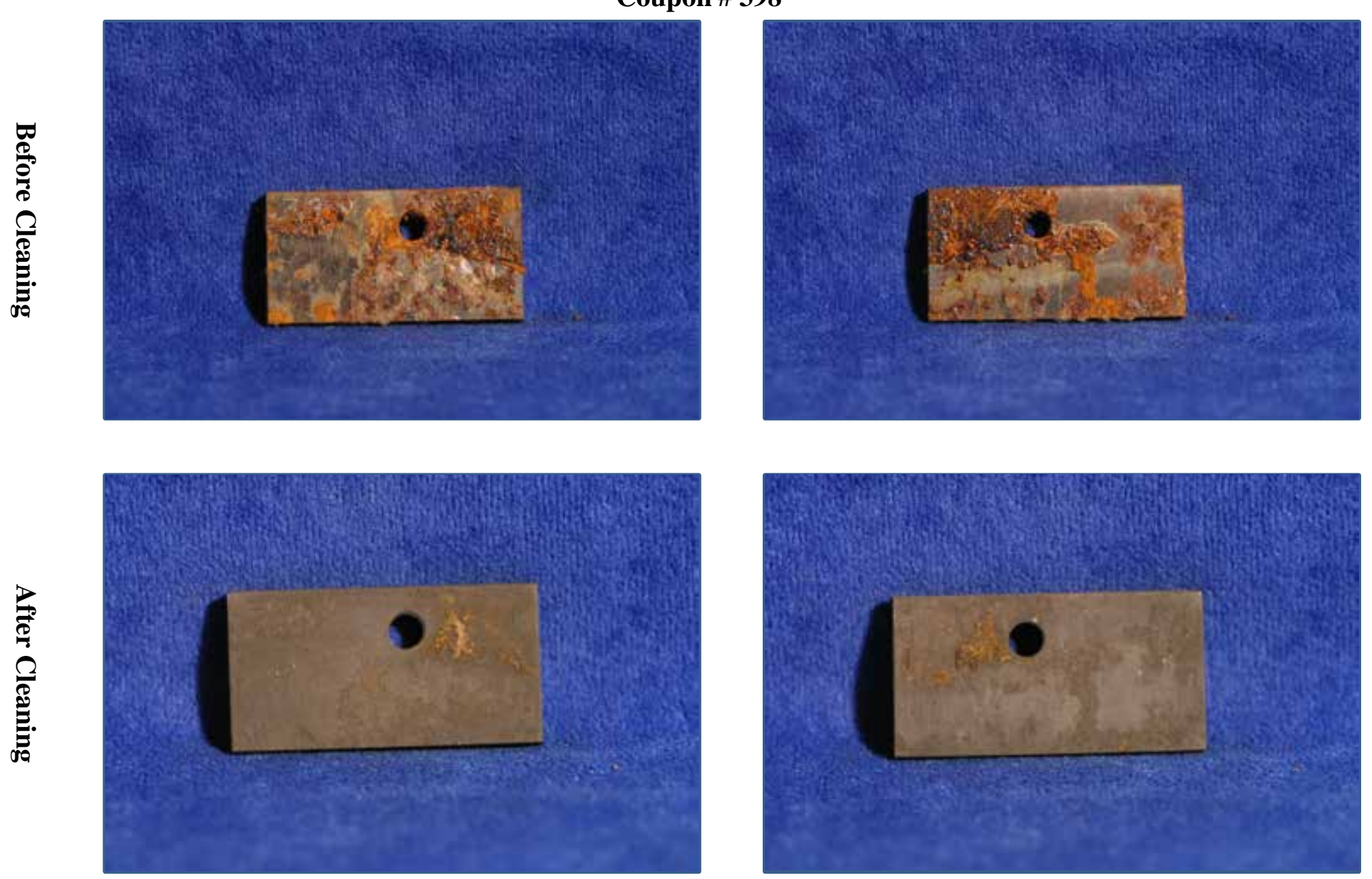
Solution 1 - 4 Months

\section{Coupon \# 399}
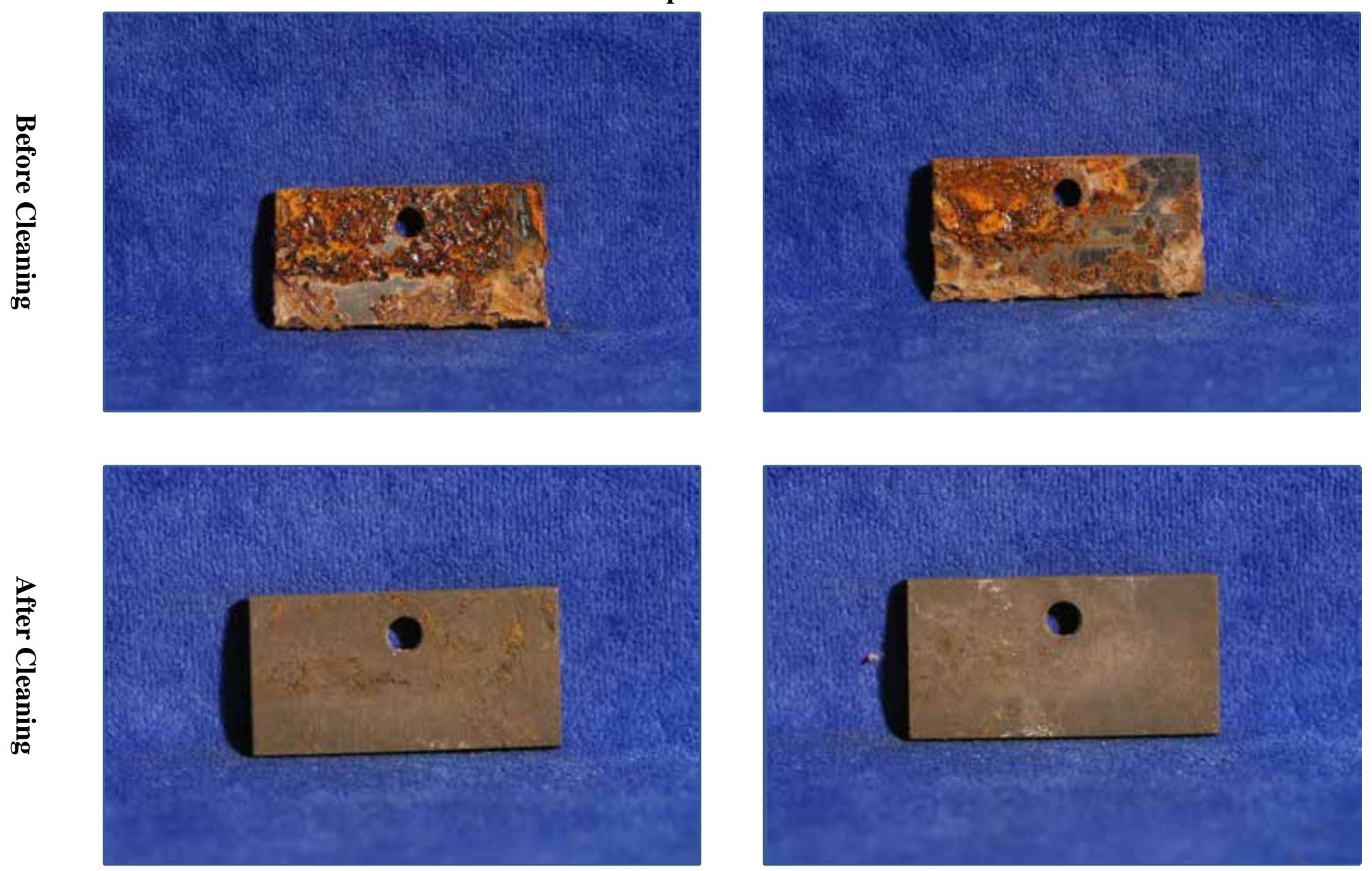
Solution 1 - 4 Months

\section{Coupon \# 400}
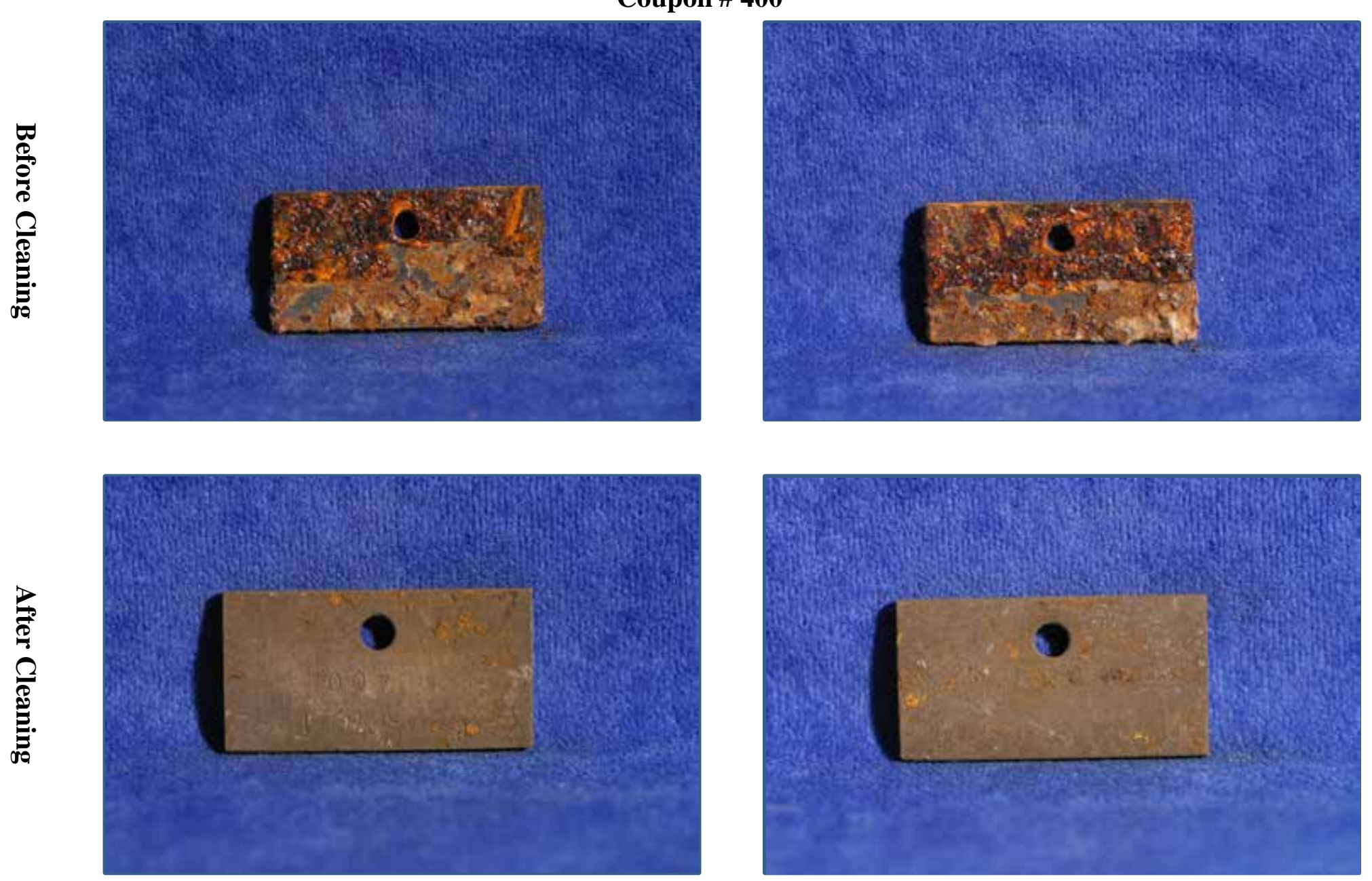
Solution 2 - 2 Months

Coupon \# 403
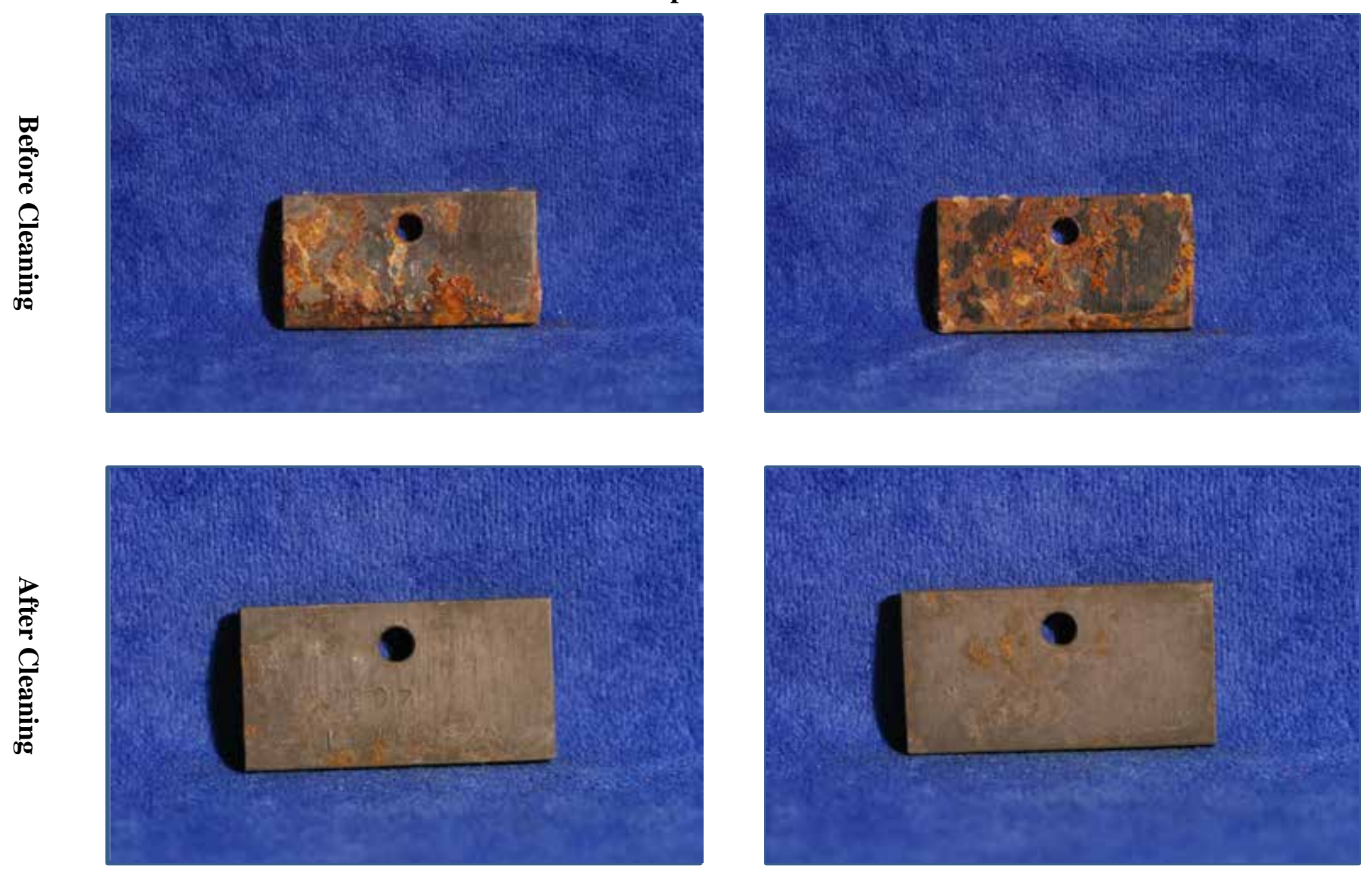
Solution 2 - 2 Months

\section{Coupon \# 404}
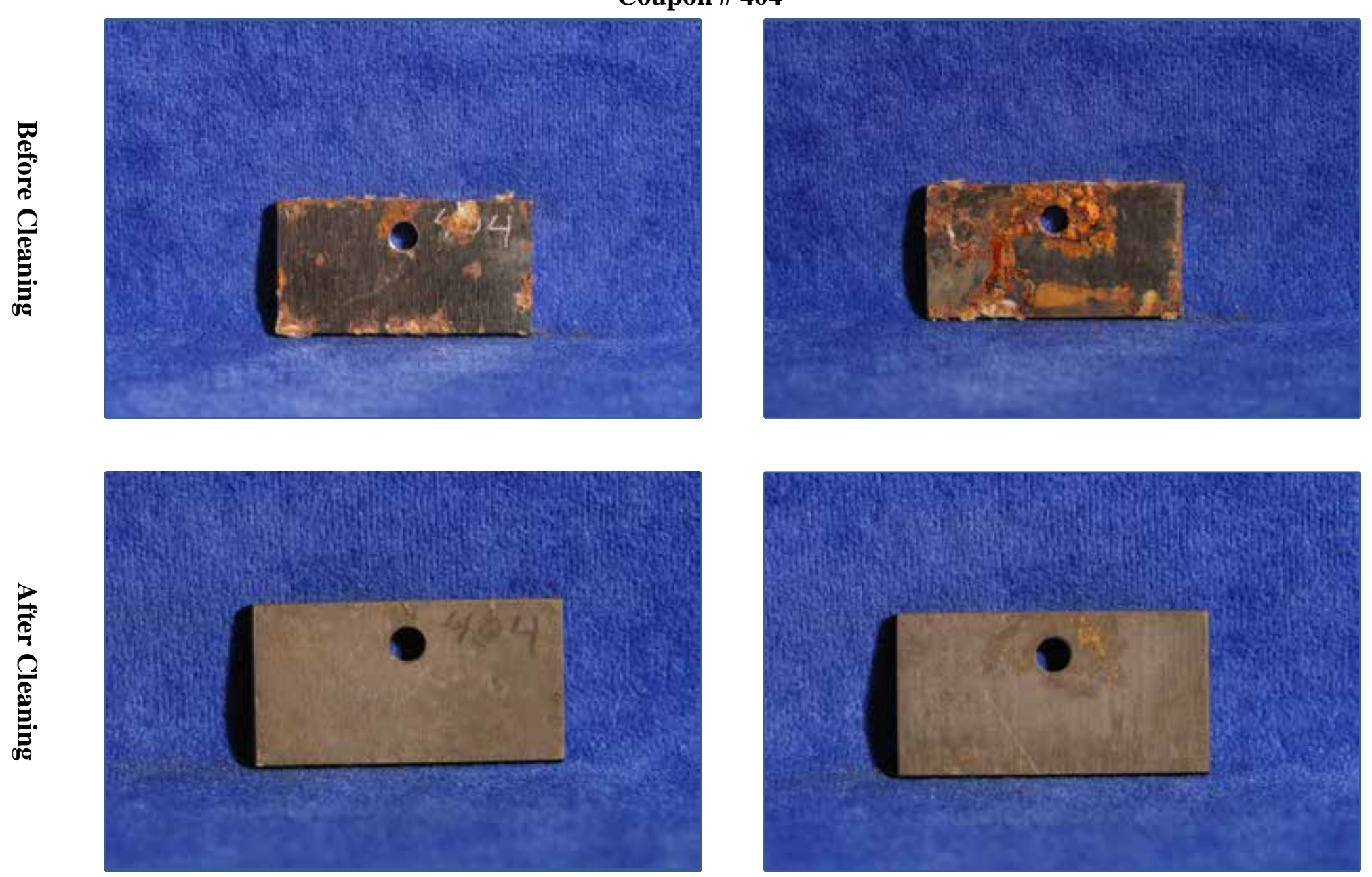
Solution 2 - 4 Months

Coupon \# 401
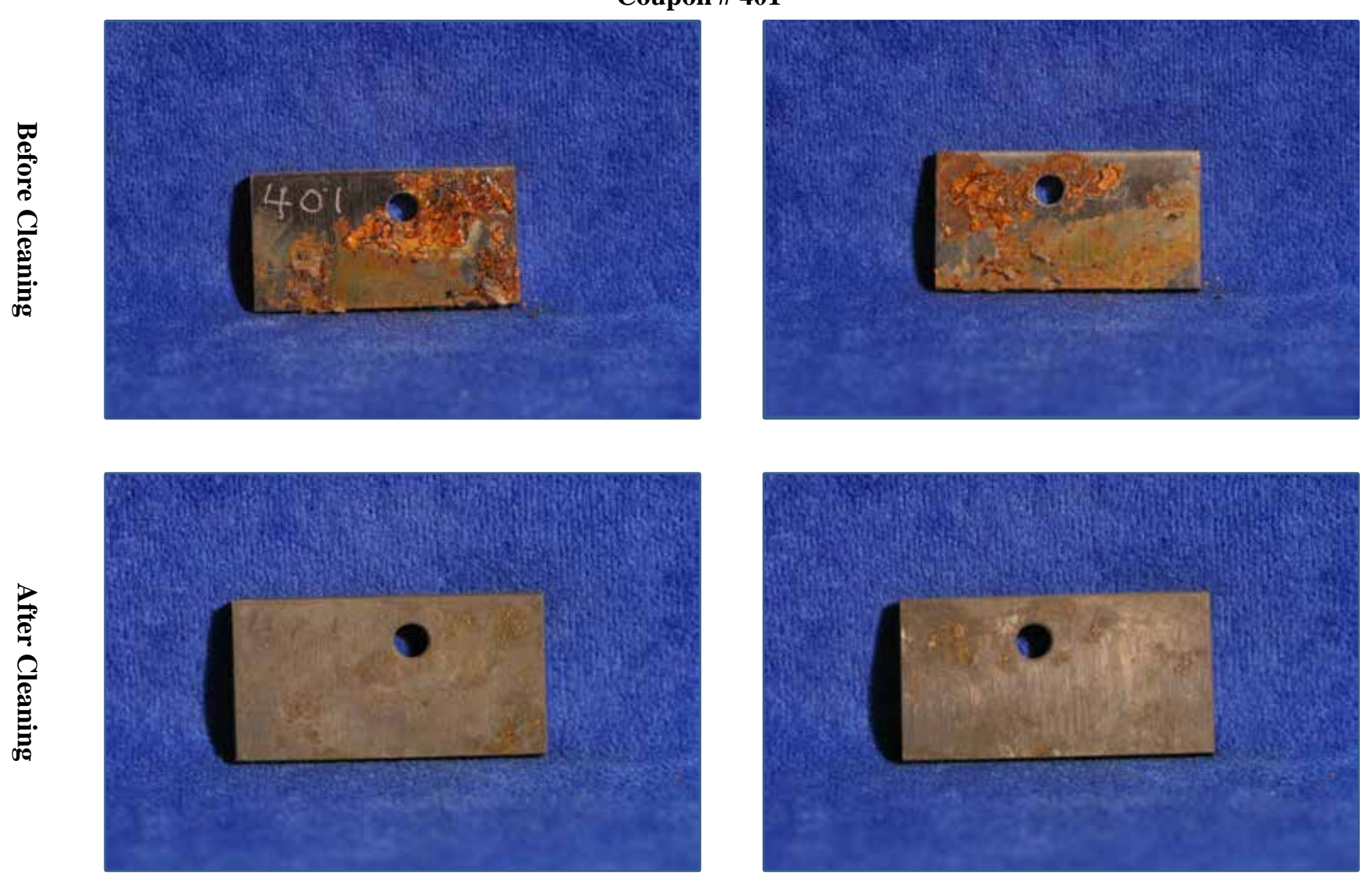
Solution 2-4 Months

Coupon \# 402
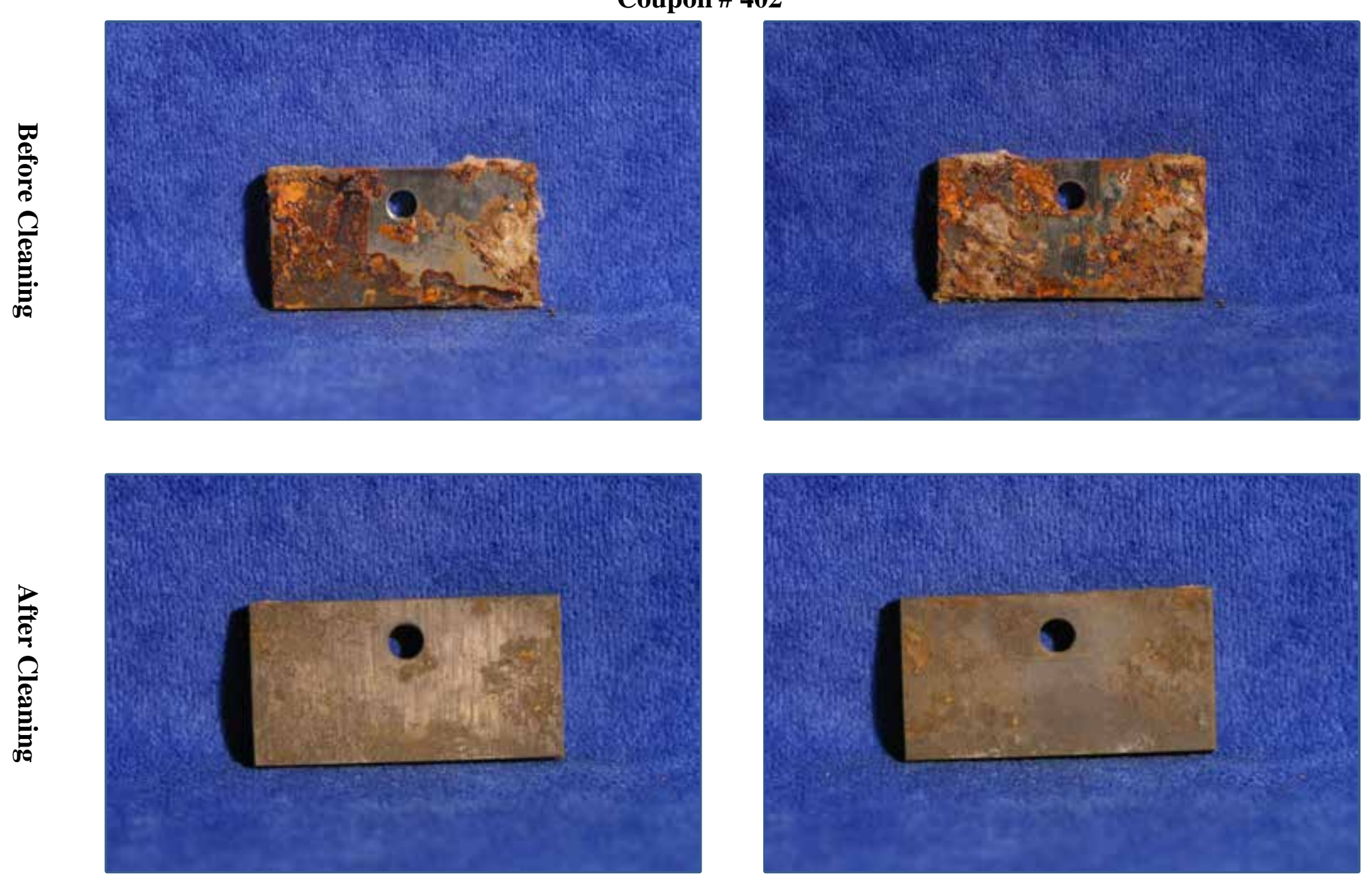
Solution 3 - 2 Months

\section{Coupon \# 452}
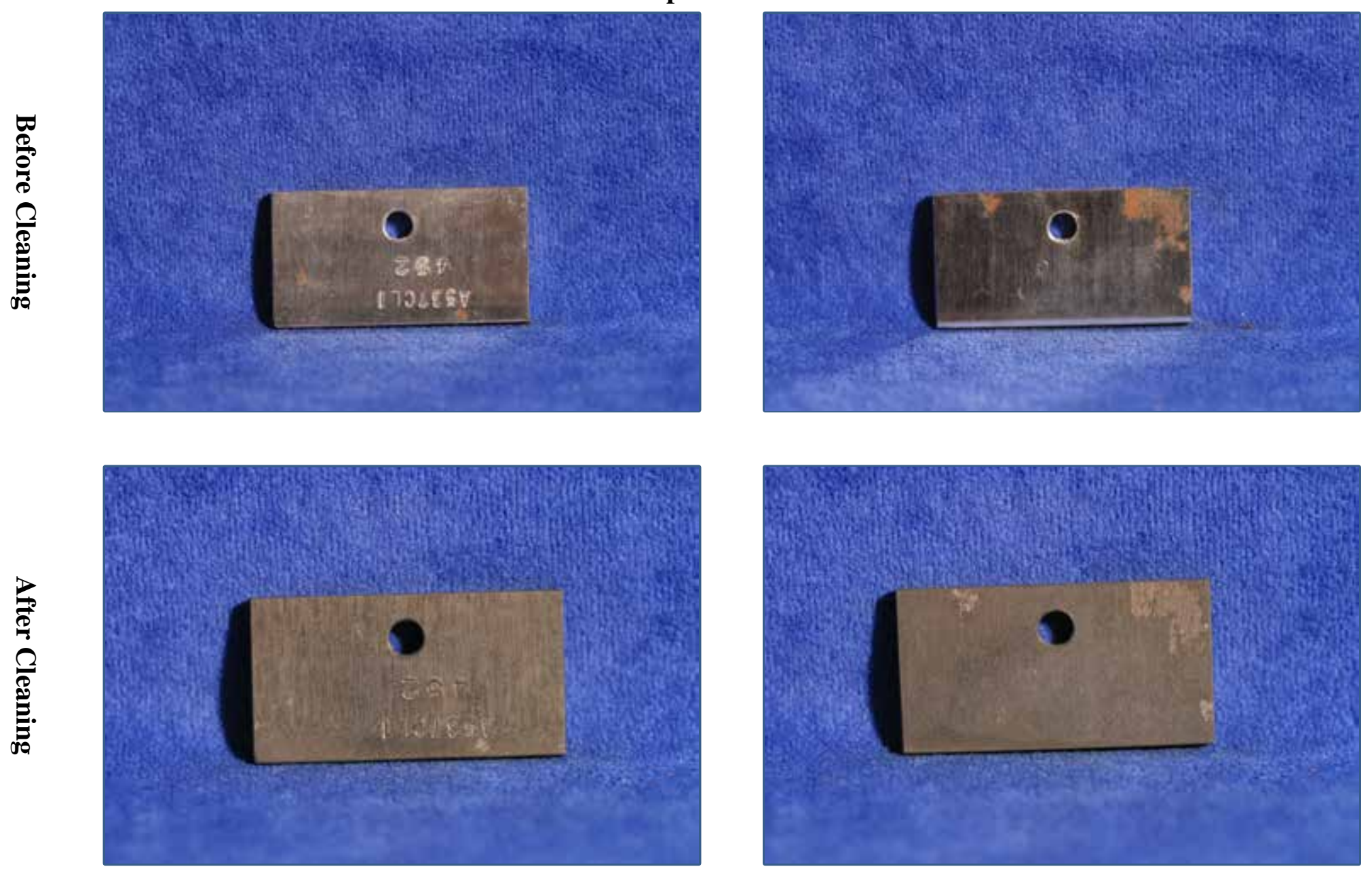
Solution 3 - 2 Months

Coupon \# 456
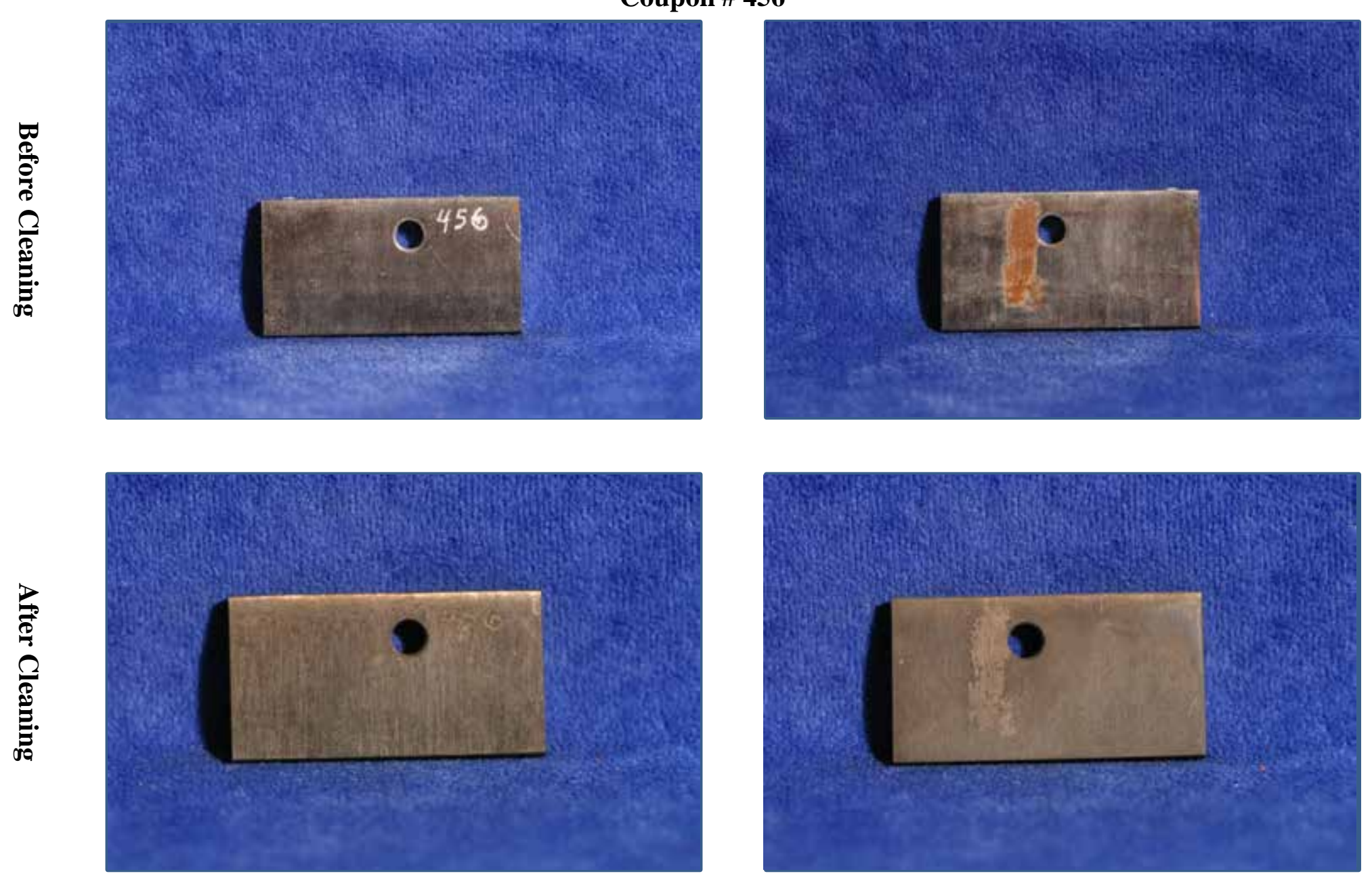
Solution 3-4 Months

Coupon \# 454
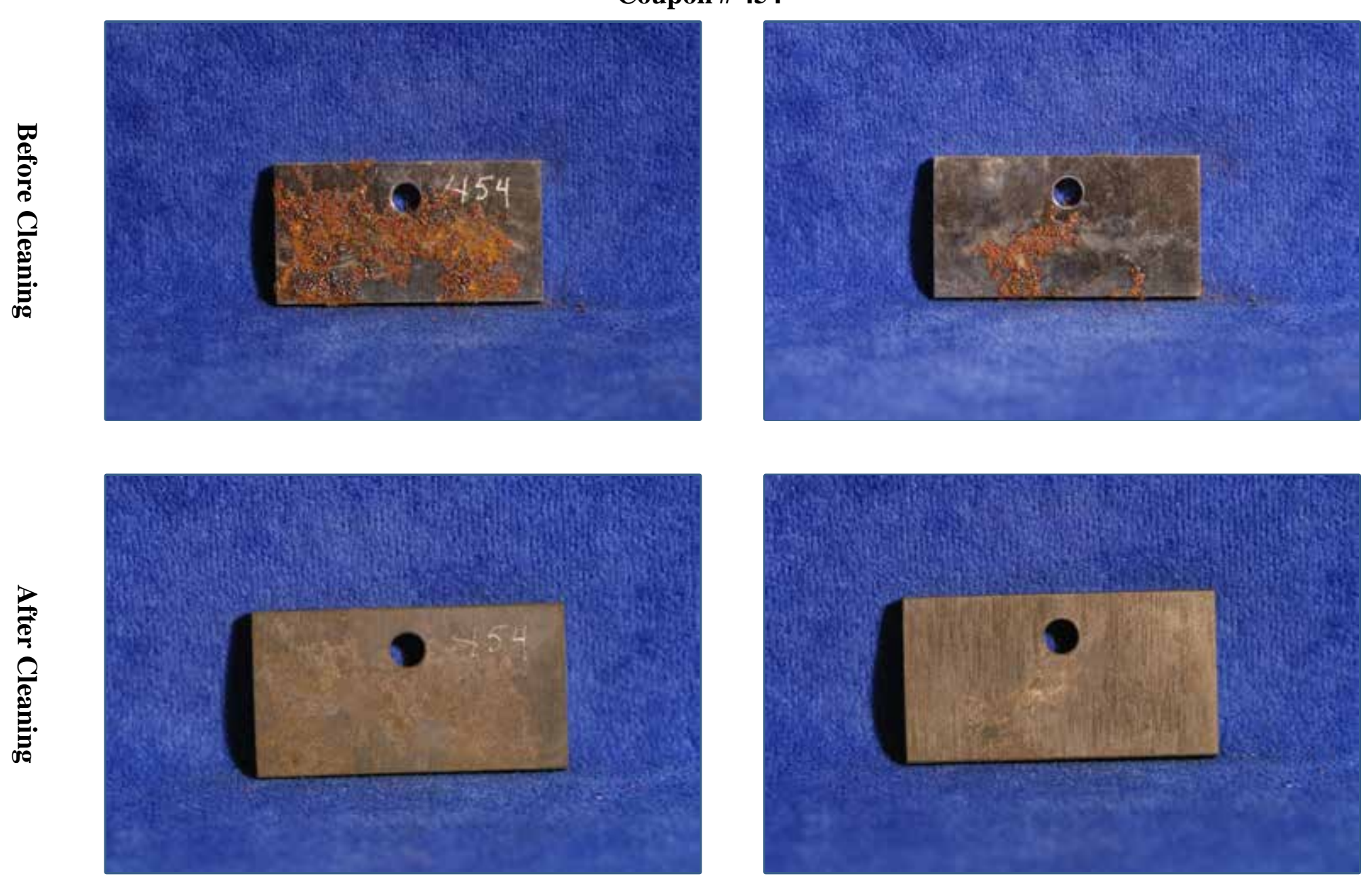
Solution 3-4 Months

Coupon \# 455
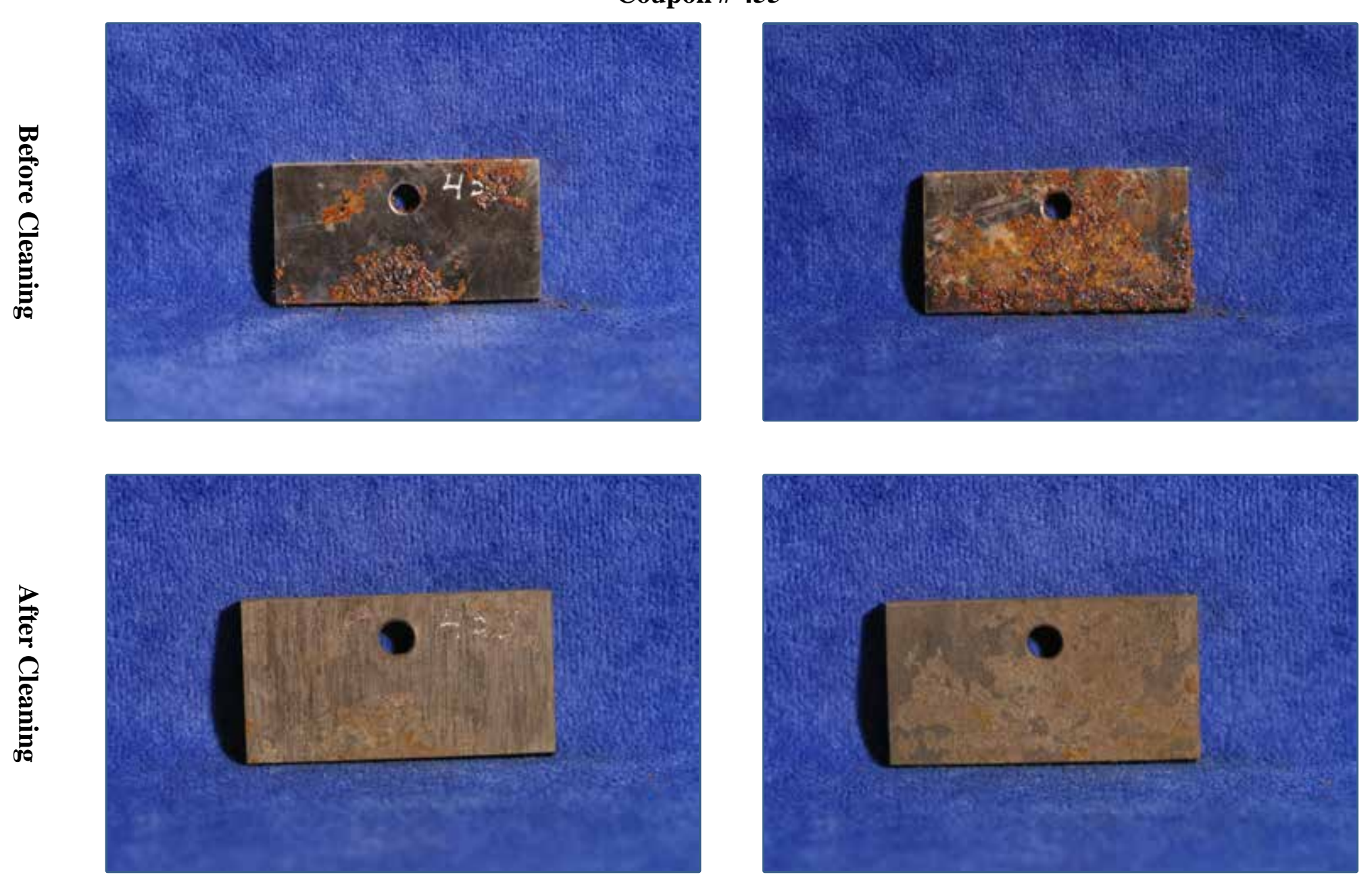


\section{Visual Observations and Pit Measurements of Coupons*}

Solution 1

\begin{tabular}{|c|c|c|c|c|c|}
\hline Time (mo.) & Coupon \# & Depth (mils) & Diameter (mils) & Depth/Diameter & Qualitative Density Estimate \\
\hline \multirow{10}{*}{2} & \multirow{5}{*}{397} & 4.9 & 24.5 & 0.20 & \multirow{5}{*}{$\begin{array}{l}\text { Distinct LAI. Attack goes } \\
\text { above LAI. Limited attack } \\
\text { beneath LAI. }\end{array}$} \\
\hline & & 3.1 & 9.9 & 0.31 & \\
\hline & & 4 & 12.5 & 0.32 & \\
\hline & & 4 & NA & NA & \\
\hline & & 1.5 & 7.5 & 0.20 & \\
\hline & \multirow{5}{*}{398} & 2 & 10.8 & 0.19 & \multirow{5}{*}{$\begin{array}{l}\text { Distinct LAI. Attack goes } \\
\text { above LAI. Limited attack } \\
\text { beneath LAI. }\end{array}$} \\
\hline & & 2.1 & 5.4 & 0.39 & \\
\hline & & 2.1 & NA & NA & \\
\hline & & 2.4 & 9.6 & 0.25 & \\
\hline & & 2.6 & 7.8 & 0.33 & \\
\hline \multirow{10}{*}{4} & \multirow{5}{*}{399} & 4.9 & 25.5 & 0.19 & \multirow{5}{*}{$\begin{array}{l}\text { Distinct LAI. Attack goes } \\
\text { above LAI. Limited attack } \\
\text { beneath LAI. }\end{array}$} \\
\hline & & 3.2 & 12.7 & 0.25 & \\
\hline & & 2.7 & 9.2 & 0.29 & \\
\hline & & 4.1 & 16.1 & 0.25 & \\
\hline & & 7.7 & 14.9 & 0.52 & \\
\hline & \multirow{5}{*}{400} & 1.9 & 13.1 & 0.15 & \multirow{5}{*}{$\begin{array}{l}\text { Distinct LAI. Attack goes } \\
\text { above LAI. Limited attack } \\
\text { beneath LAI. }\end{array}$} \\
\hline & & 2.8 & 15.1 & 0.19 & \\
\hline & & 2.3 & 12.3 & 0.19 & \\
\hline & & 5.2 & 14.8 & 0.35 & \\
\hline & & 2.2 & 7.6 & 0.29 & \\
\hline
\end{tabular}

* NA - pits within locally attacked area and difficult to discern 
Visual Observations and Pit Measurements of Coupons*

Solution 2

\begin{tabular}{|l|l|l|l|l|}
\hline Time (mo.) Coupon \# Depth (mils) & Diameter (mils) & Depth/Diameter & Qualitative Density Estimate \\
\hline & 2.8 & 9.4 & 0.30 & Distinct LAI. Attack goes \\
above LAI. Limited attack
\end{tabular}

* NA - pits within locally attacked area and difficult to discern 
Visual Observations and Pit Measurements of Coupons*

Solution 3

\begin{tabular}{|c|c|c|c|c|c|}
\hline Time (mo.) & Coupon \# & Depth (mils) & Diameter (mils) & Depth/Diameter & Qualitative Density Estimate \\
\hline \multirow{2}{*}{2} & 452 & NA & NA & NA & No Pitting. \\
\hline & 456 & NA & NA & NA & No Pitting. \\
\hline \multirow{6}{*}{4} & \multirow{5}{*}{454} & 1.3 & 6.7 & 0.19 & \multirow{5}{*}{$\begin{array}{l}\text { No Pitting. Limited attack on } \\
\text { small areas. }\end{array}$} \\
\hline & & 1.1 & 4.7 & 0.23 & \\
\hline & & 1.3 & 13.2 & 0.10 & \\
\hline & & 1.7 & 6.3 & 0.27 & \\
\hline & & 1.7 & 8.7 & 0.20 & \\
\hline & 455 & NA & NA & NA & $\begin{array}{l}\text { No Pitting. Limited attack on } \\
\text { small areas. }\end{array}$ \\
\hline
\end{tabular}

* NA - pits within locally attacked area and difficult to discern 
SRNL-STI-2013-00743

Revision 0

\section{APPENDIX C}

\section{Un-evaporated Condensate Coupon Test Data}


AN102 - 0\% Evaporation- 2 Months

\section{Coupon \# 1}
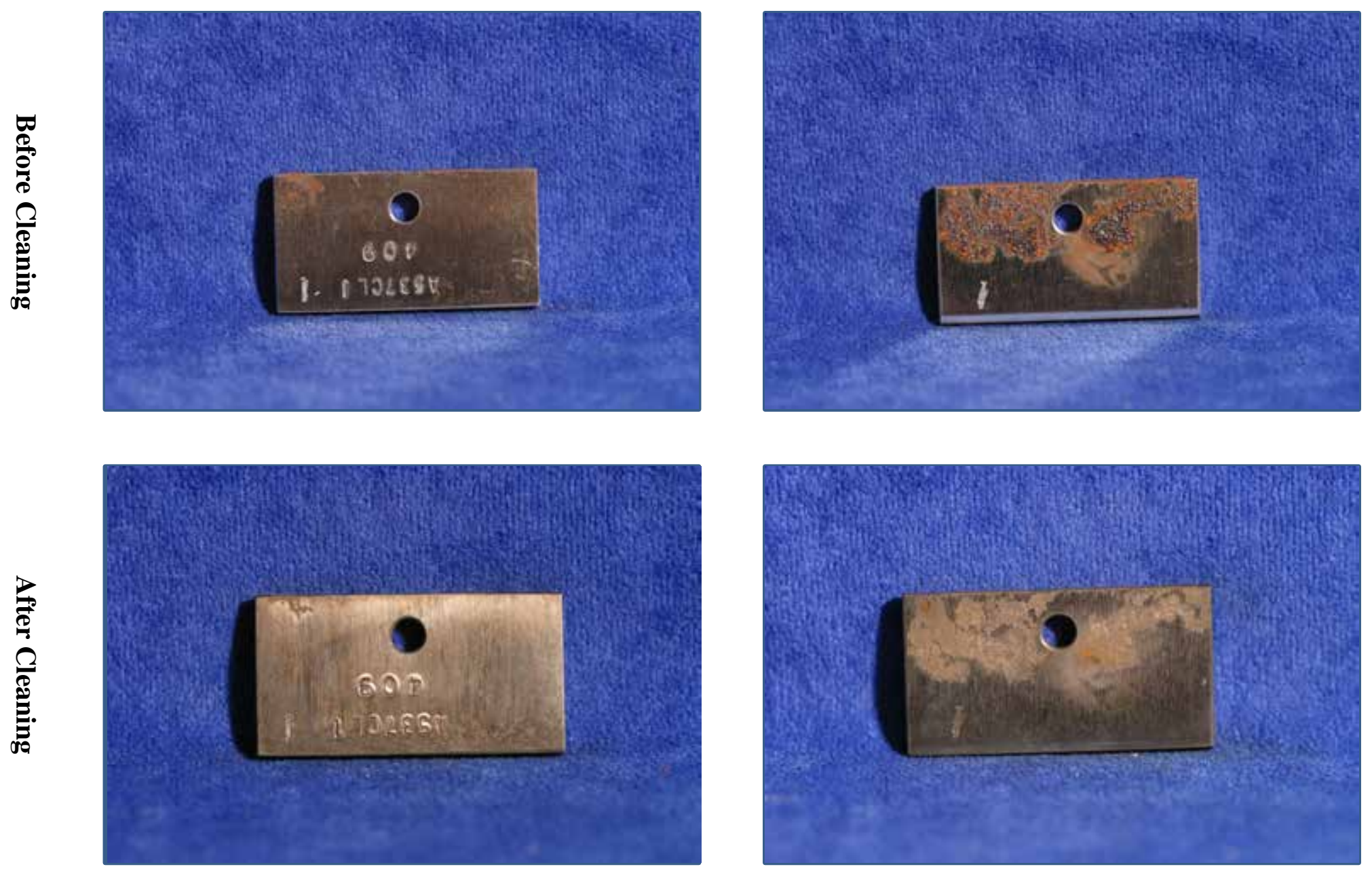
SRNL-STI-2013-00743

Revision 0

AN102 - 0\% Evaporation- 2 Months

Coupon \# 2
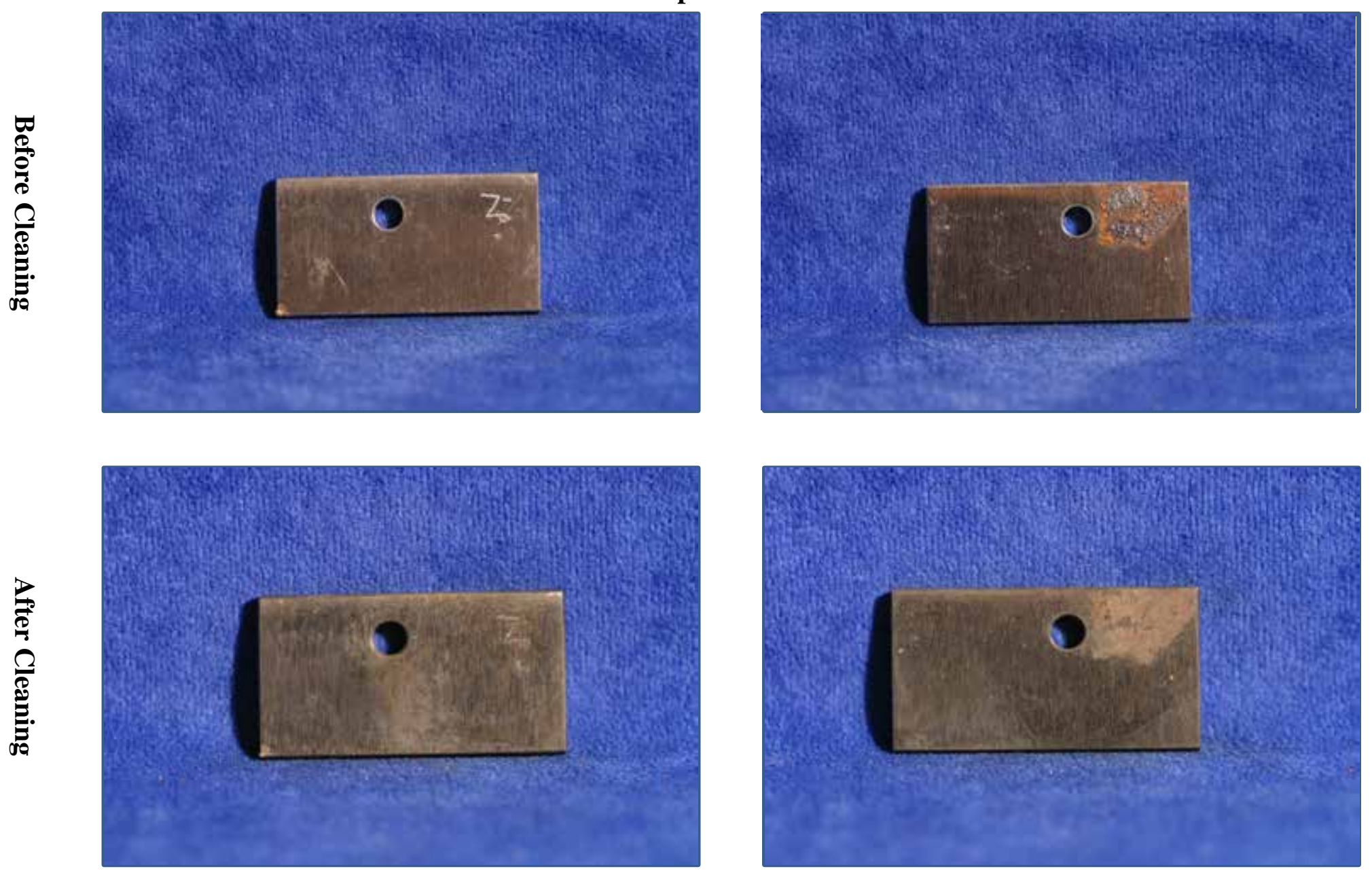
SRNL-STI-2013-00743

Revision 0

AN102 - 0\% Evaporation-4 Months

Coupon \# 3
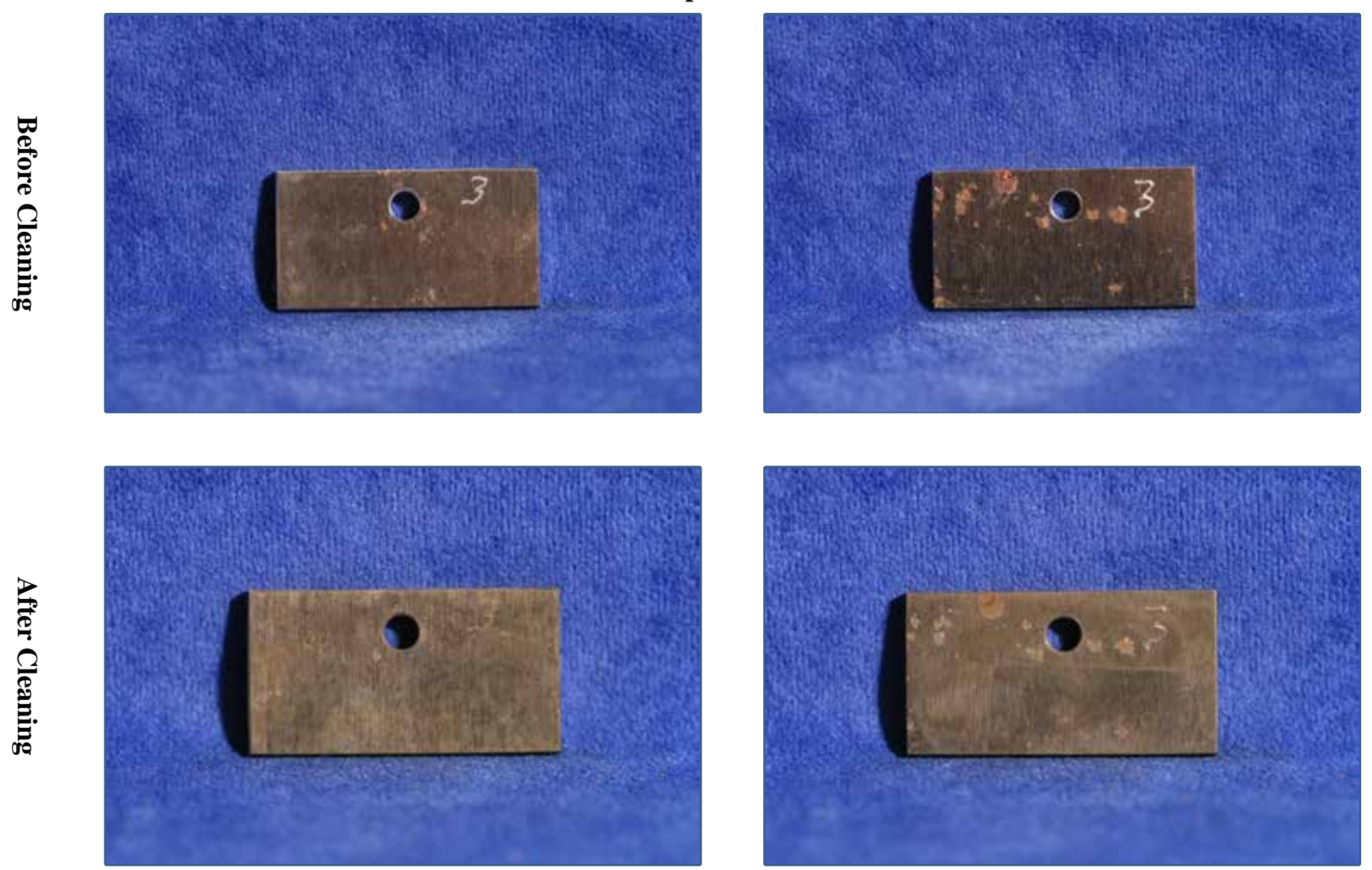
AN102 - 0\% Evaporation-4 Months

Coupon \# 4
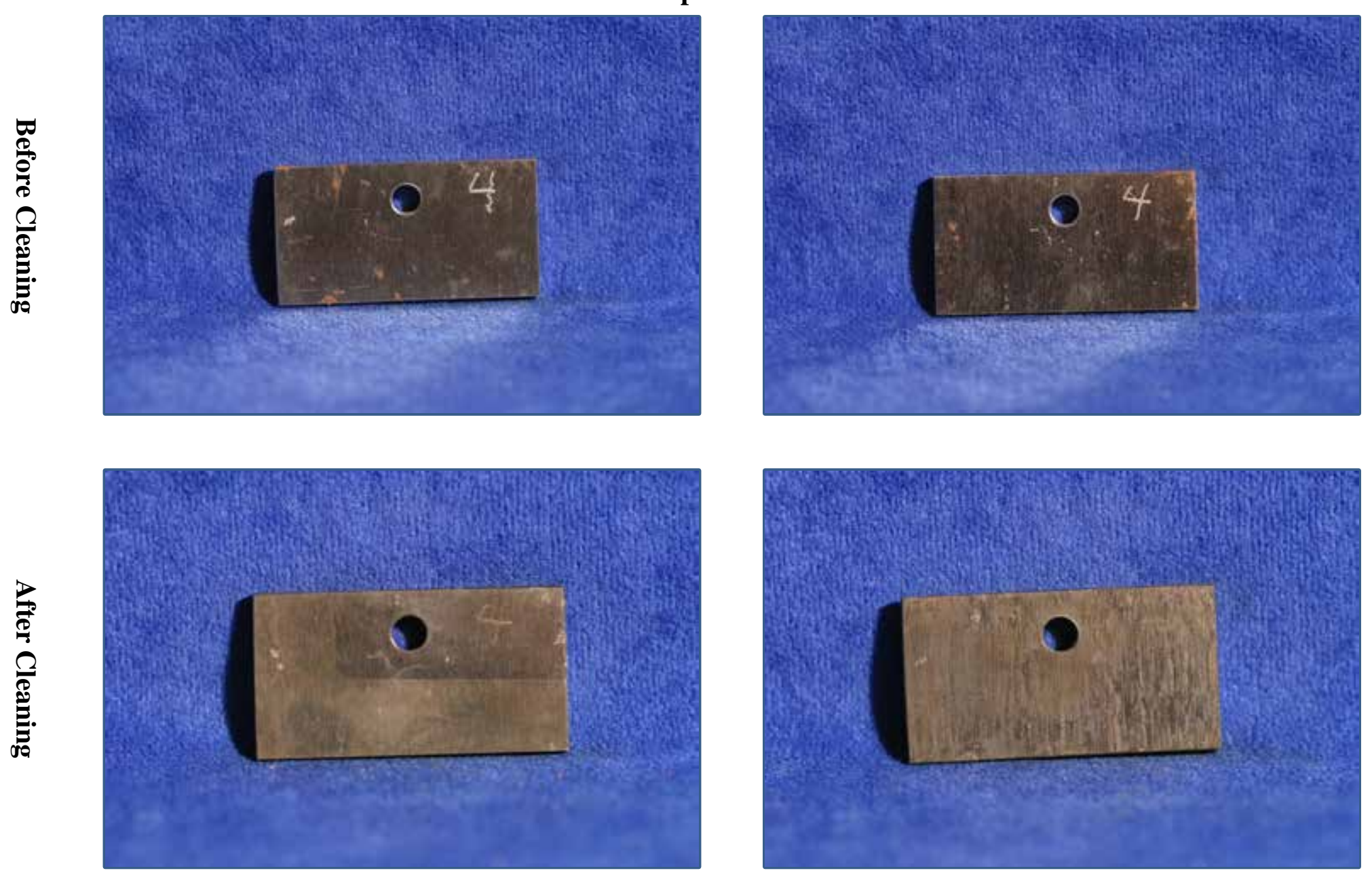


\section{Coupon \# 3}
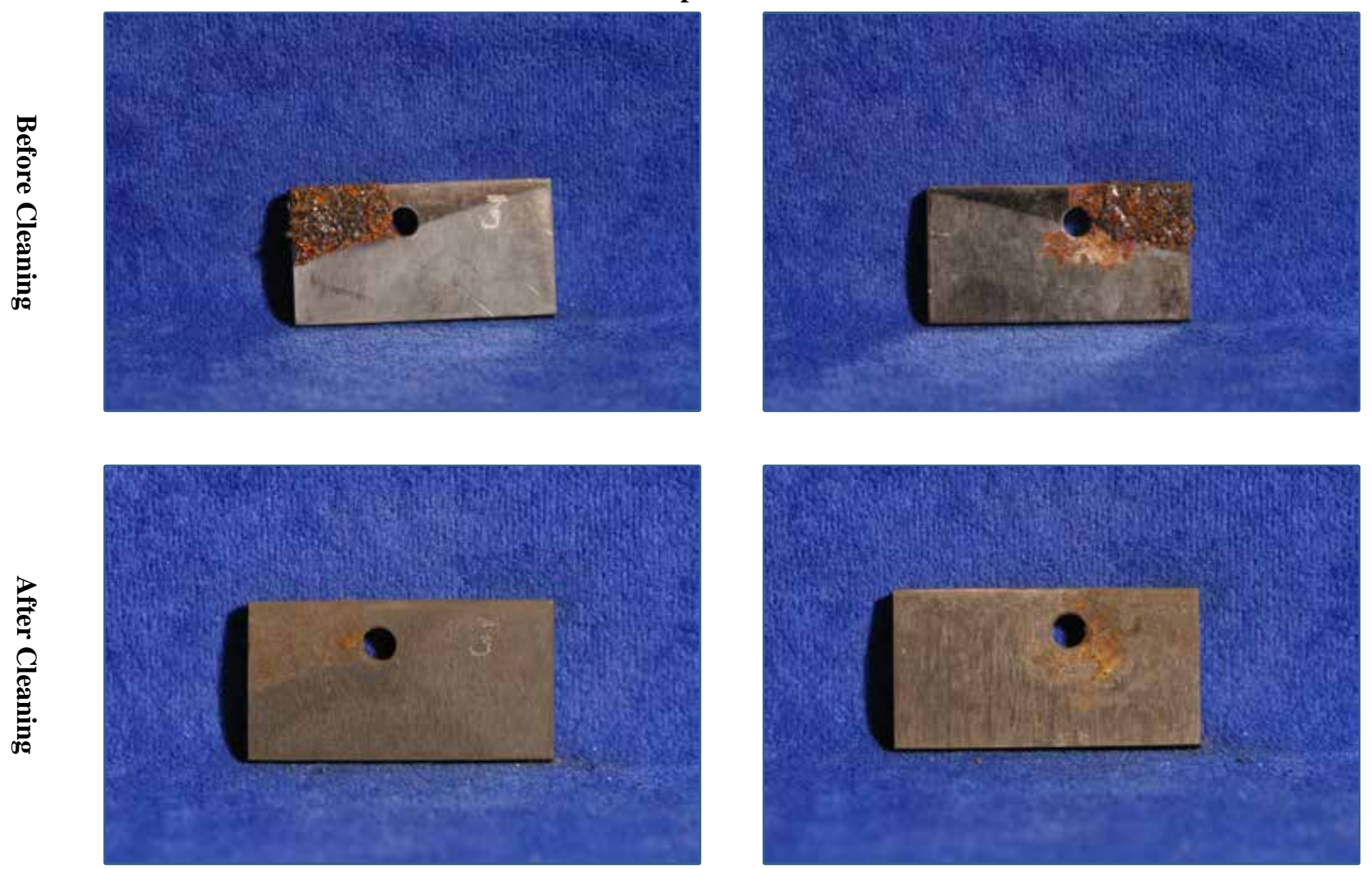

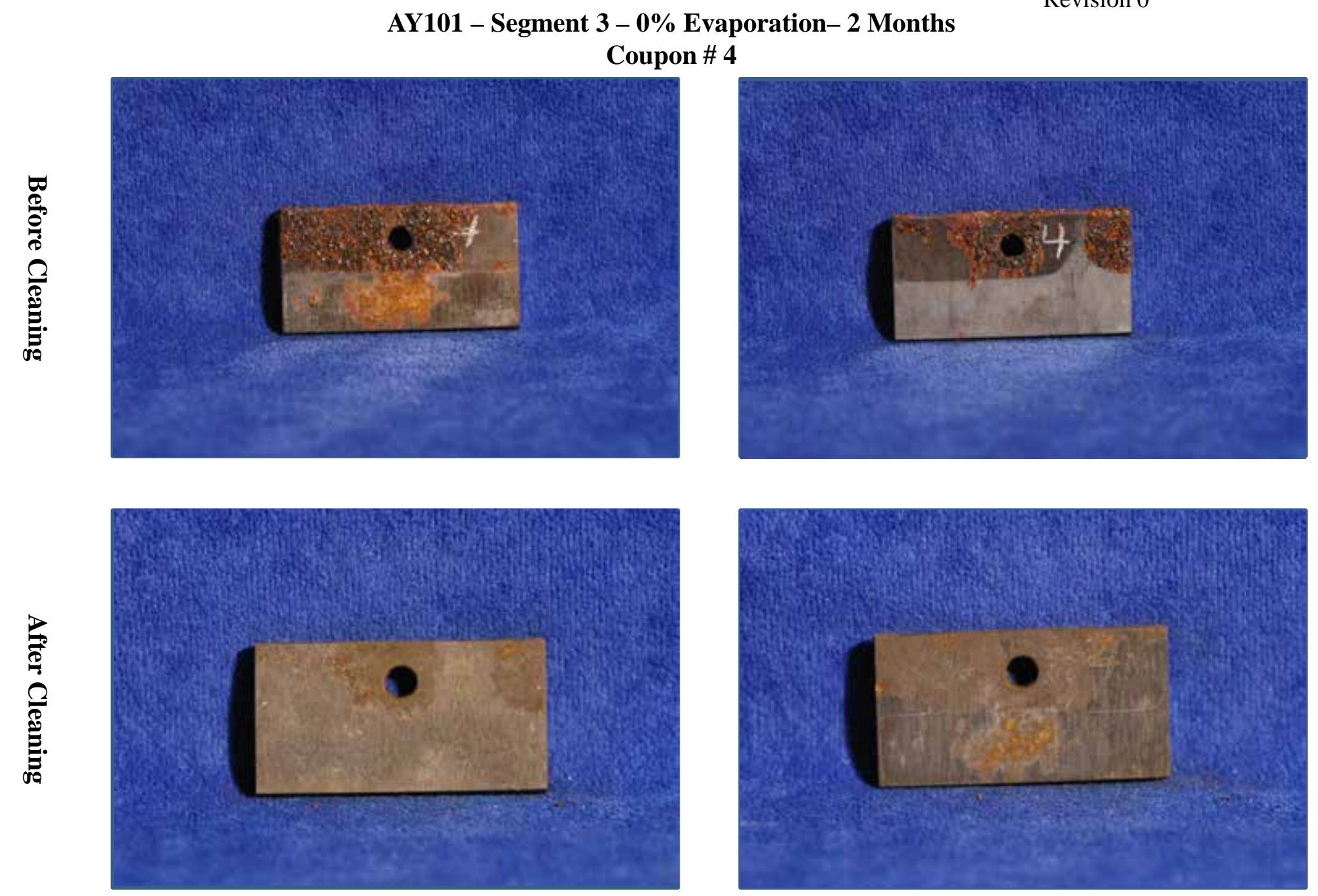


\section{Coupon \# 1}
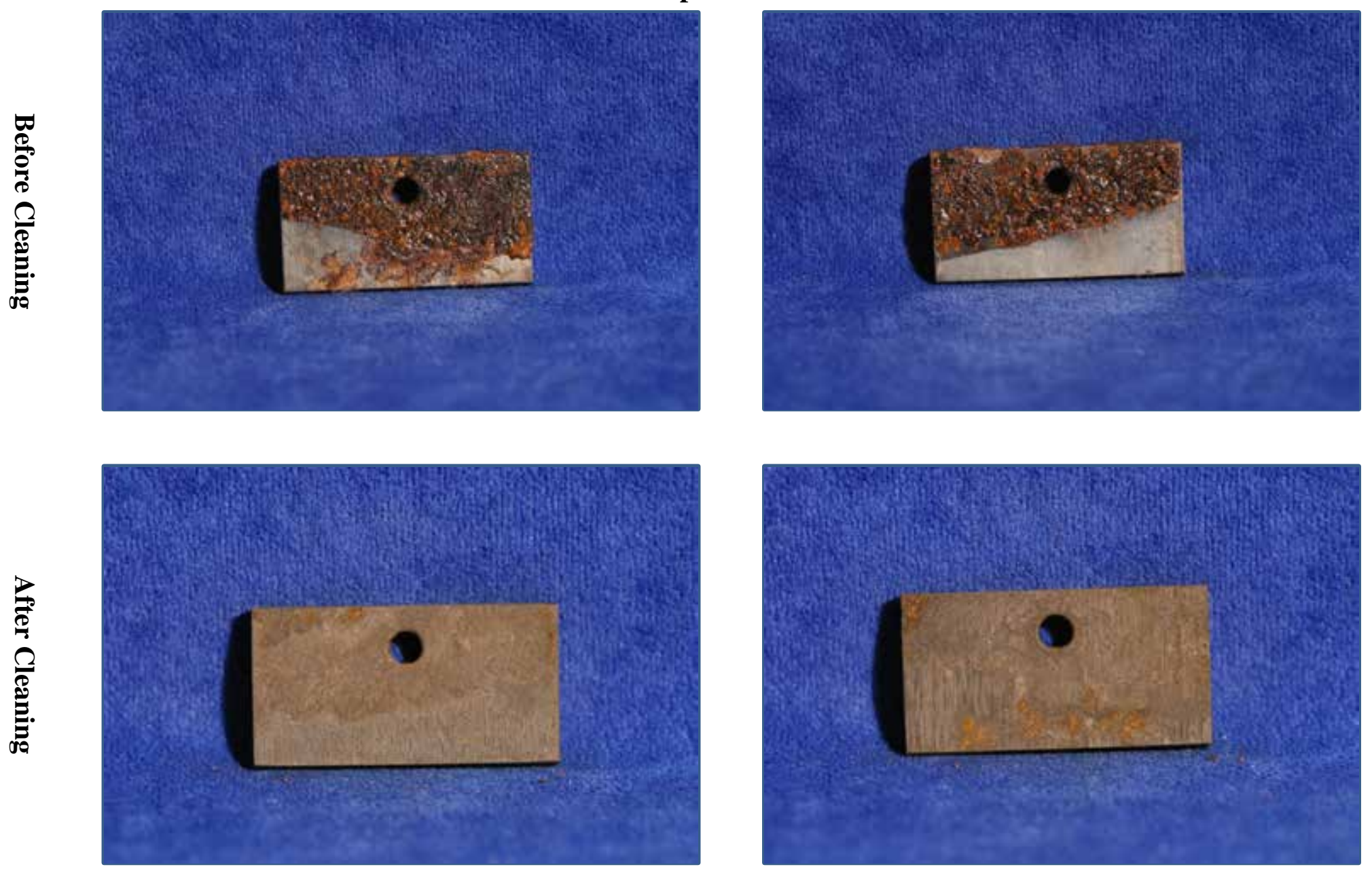

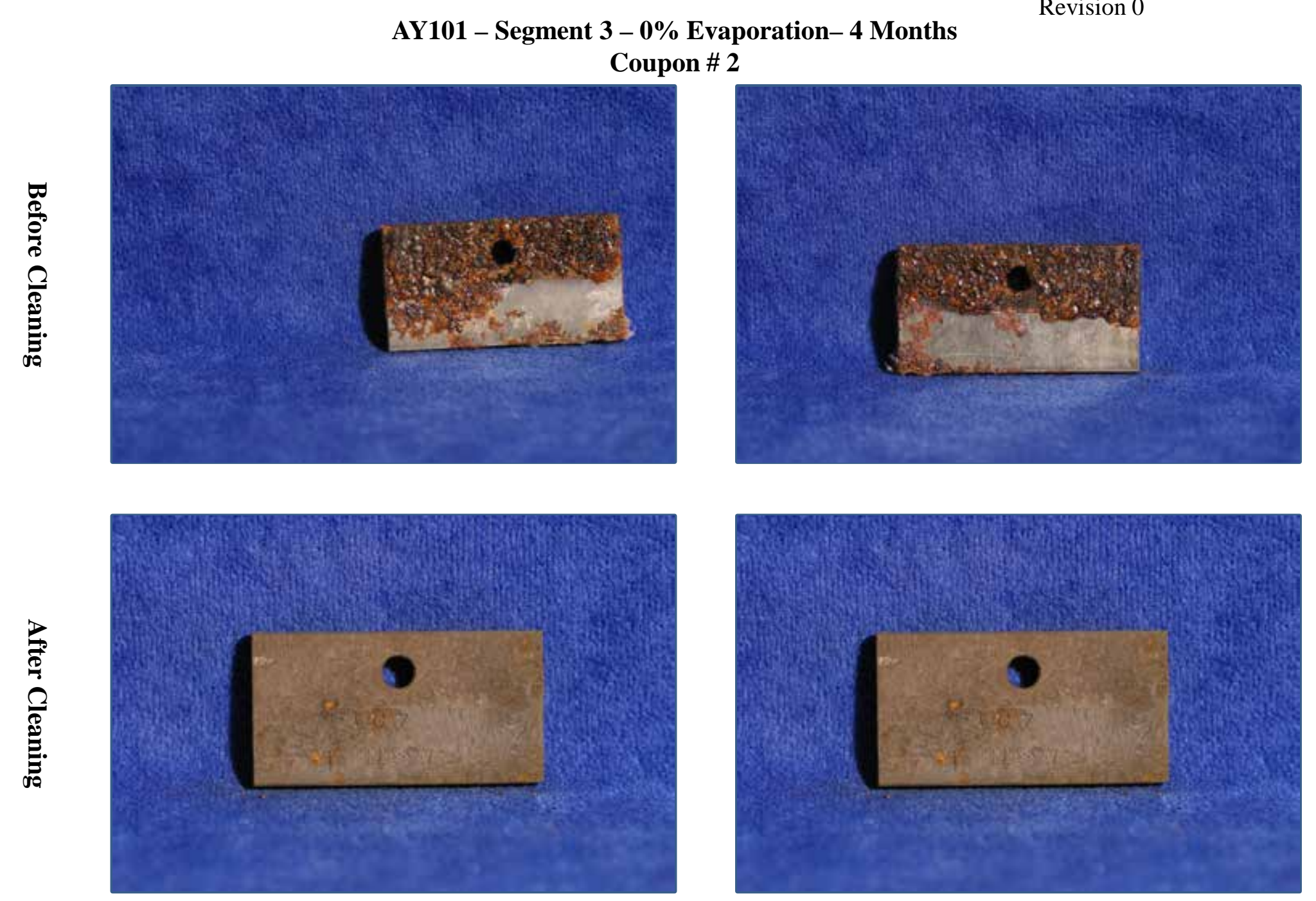
SY102 High Chloride- 0\% Evaporation- 2 Months

Coupon \# 1
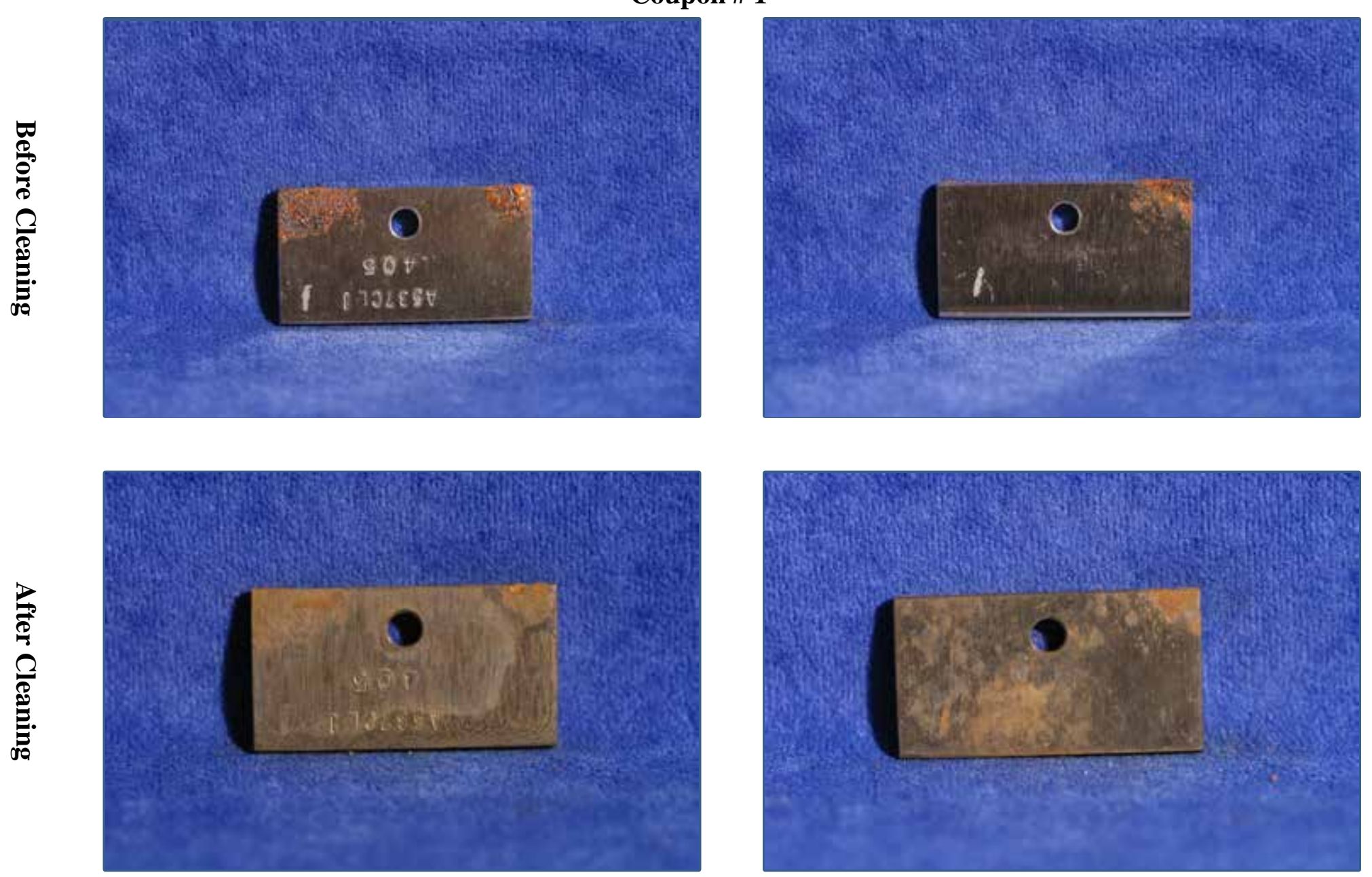
SY102 High Chloride- 0\% Evaporation- 2 Months

Coupon \# 2
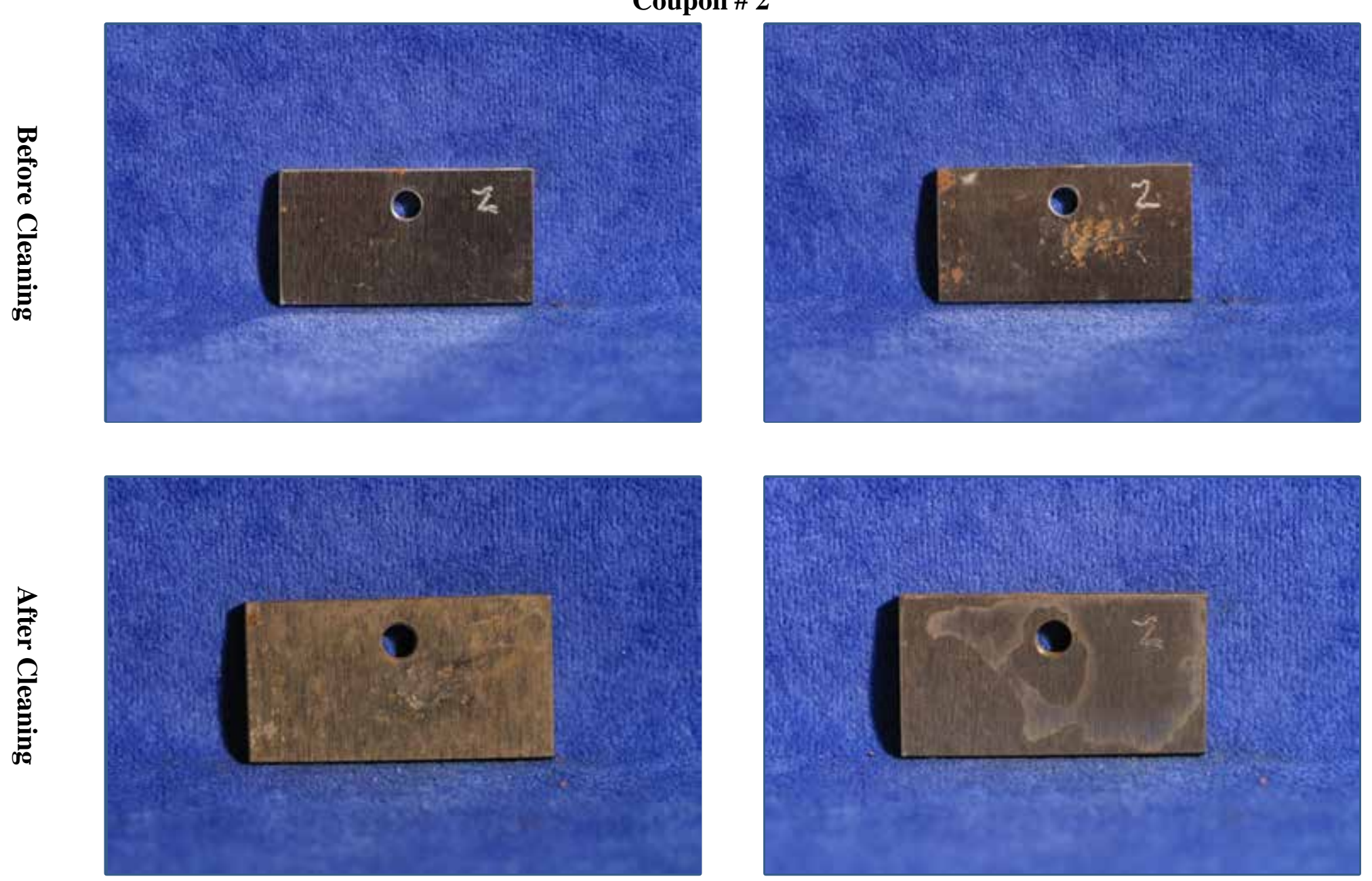
Coupon \# 3
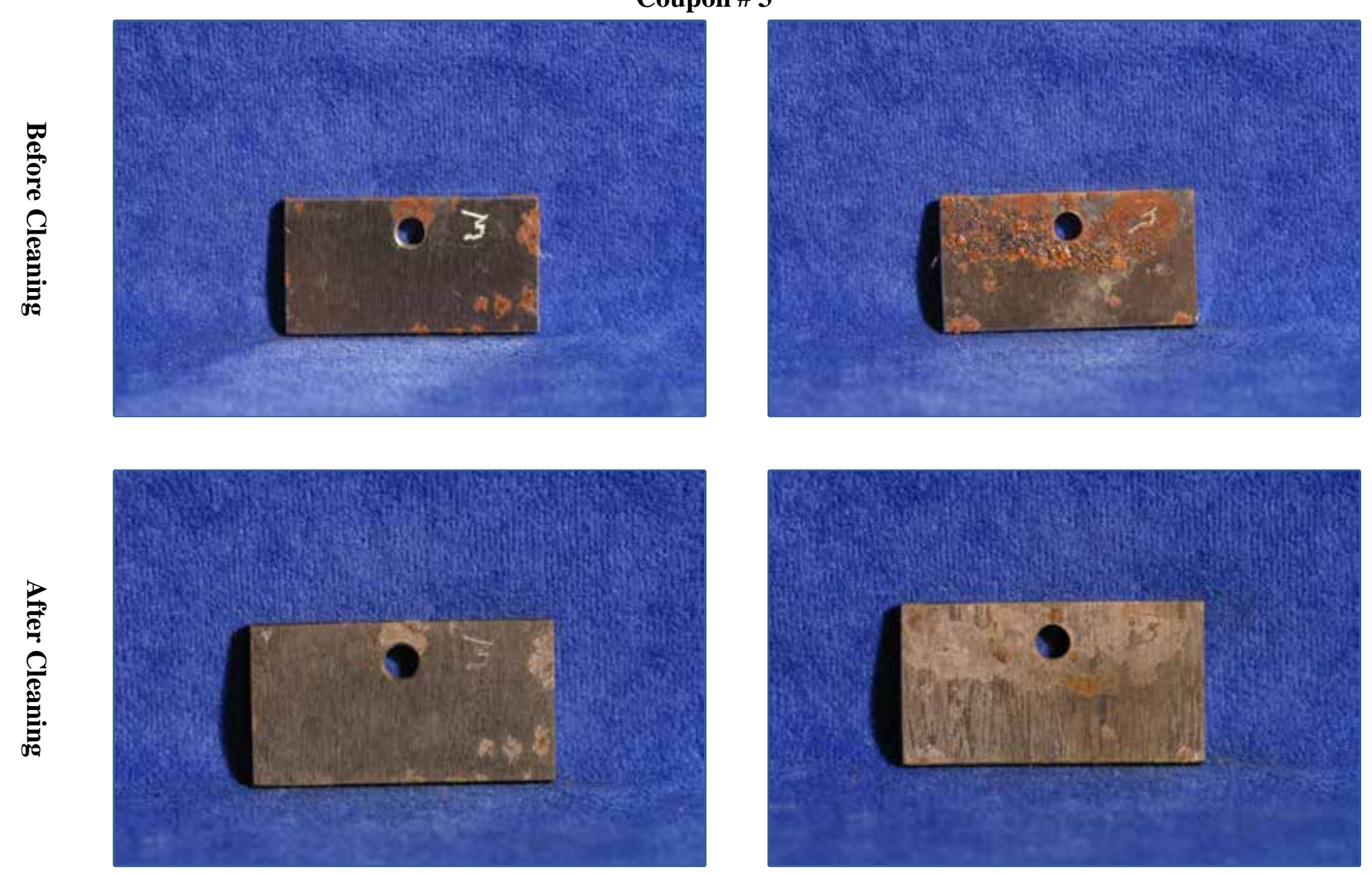


\section{Coupon \# 4}
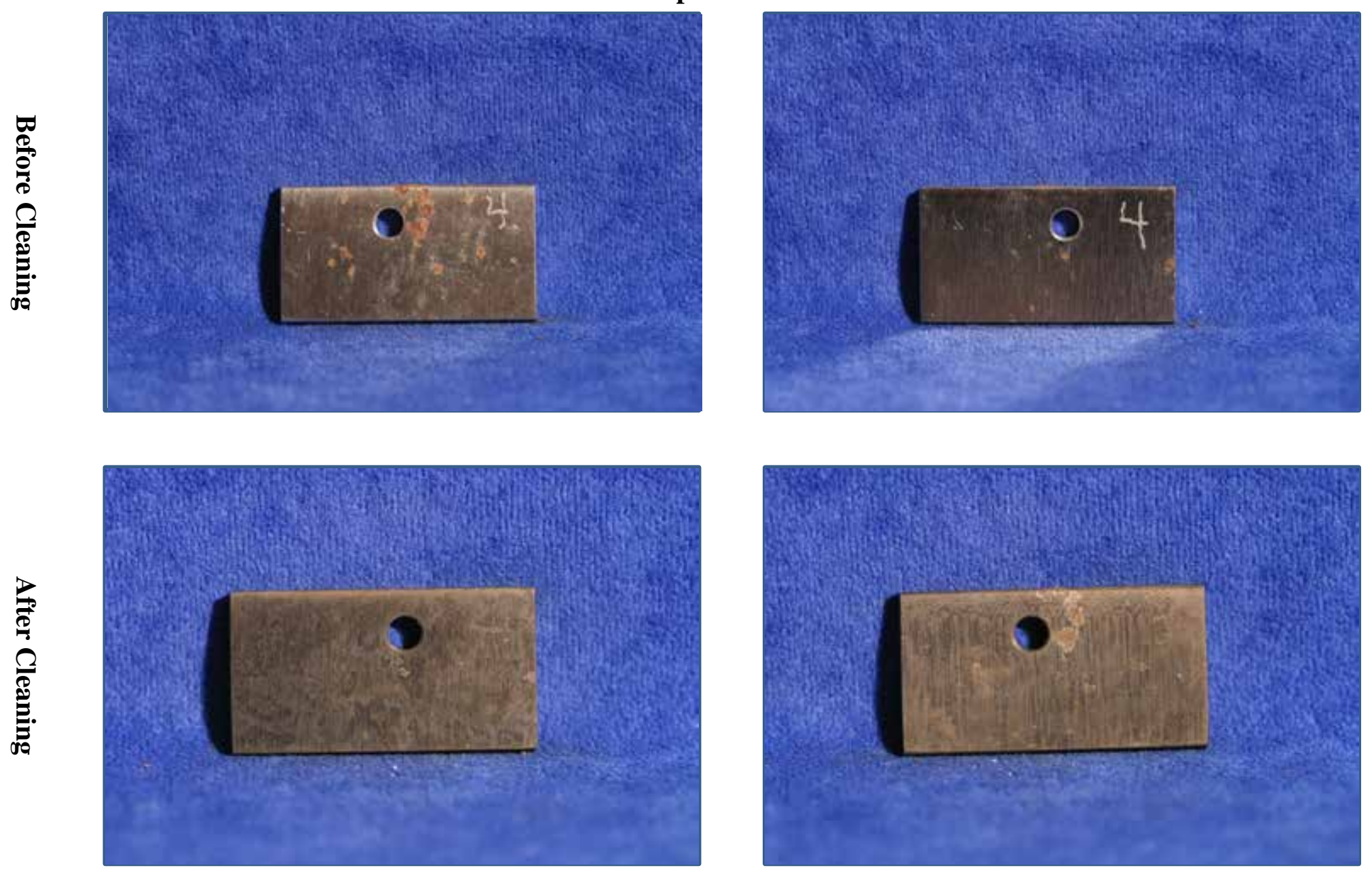


\section{Coupon \# 3}
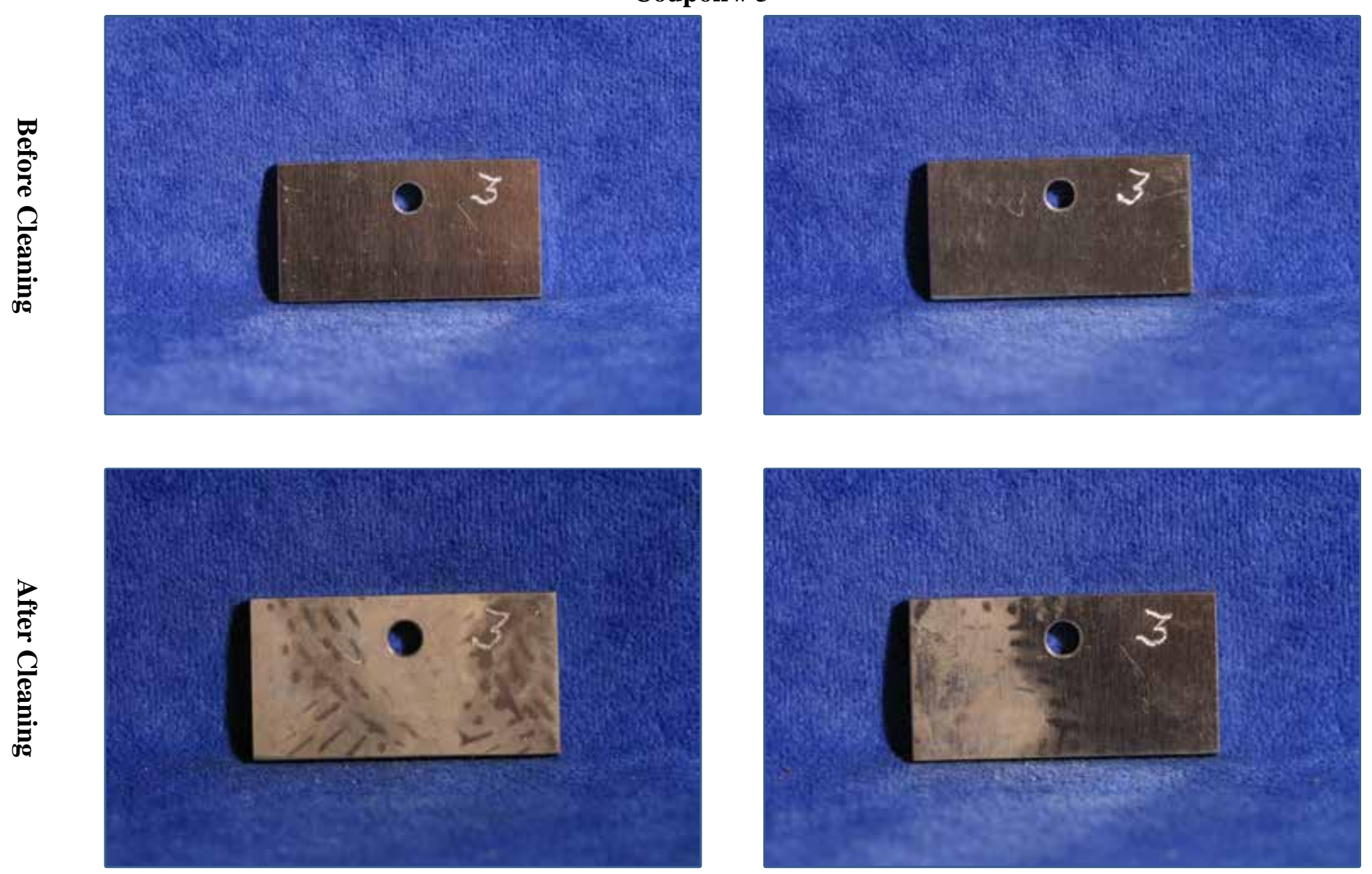
AY102 - 0\% Evaporation- 2 Months
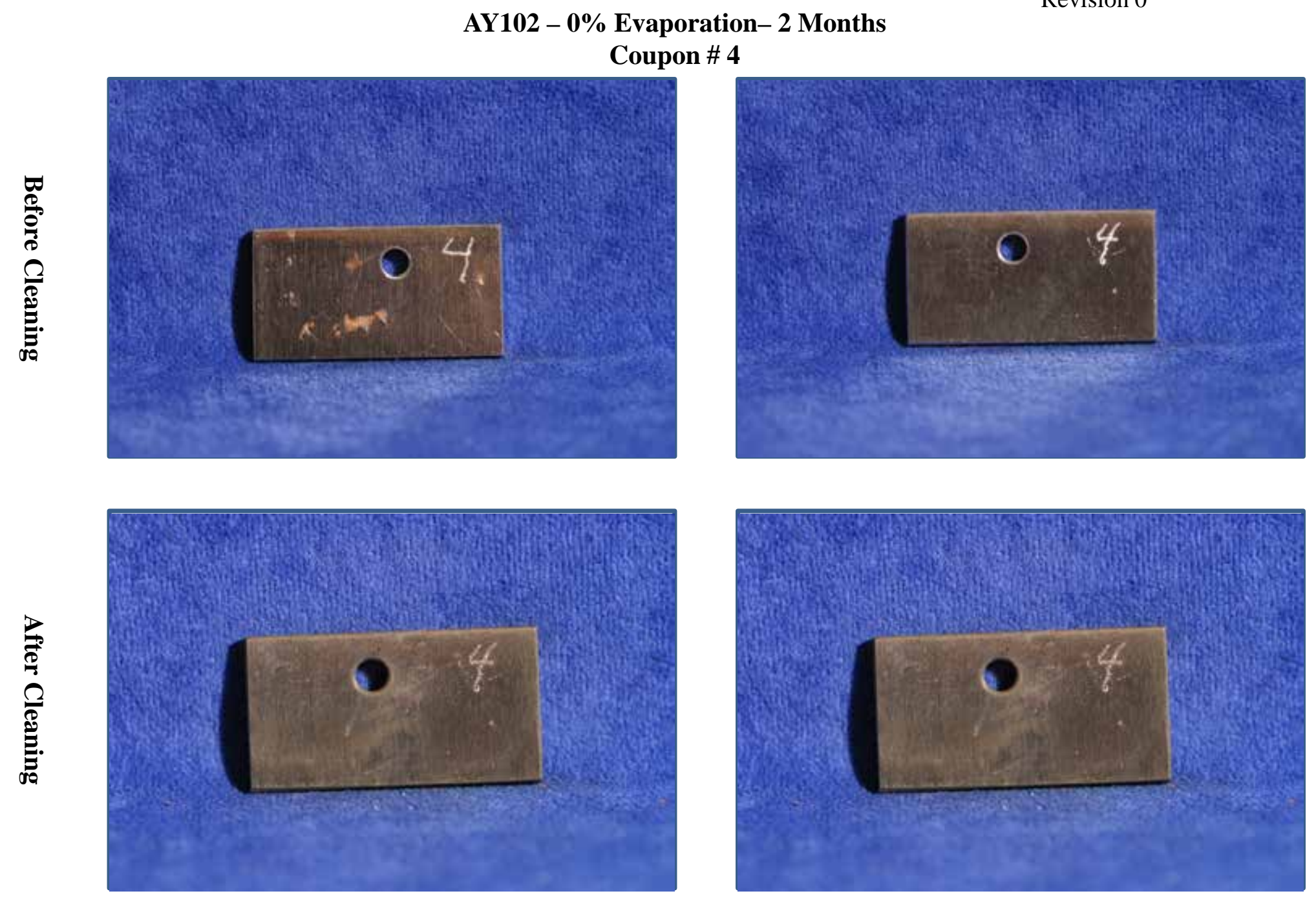

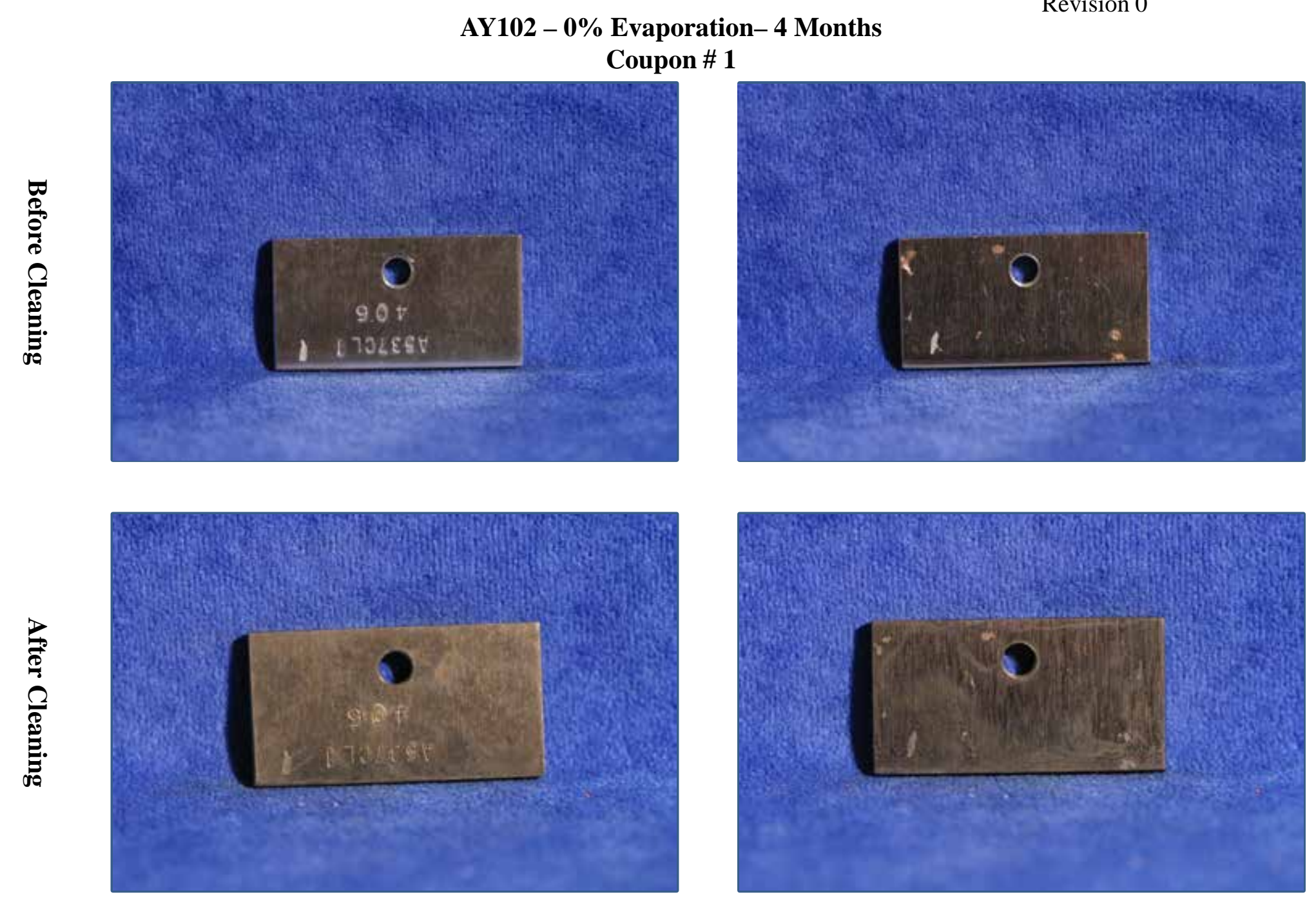

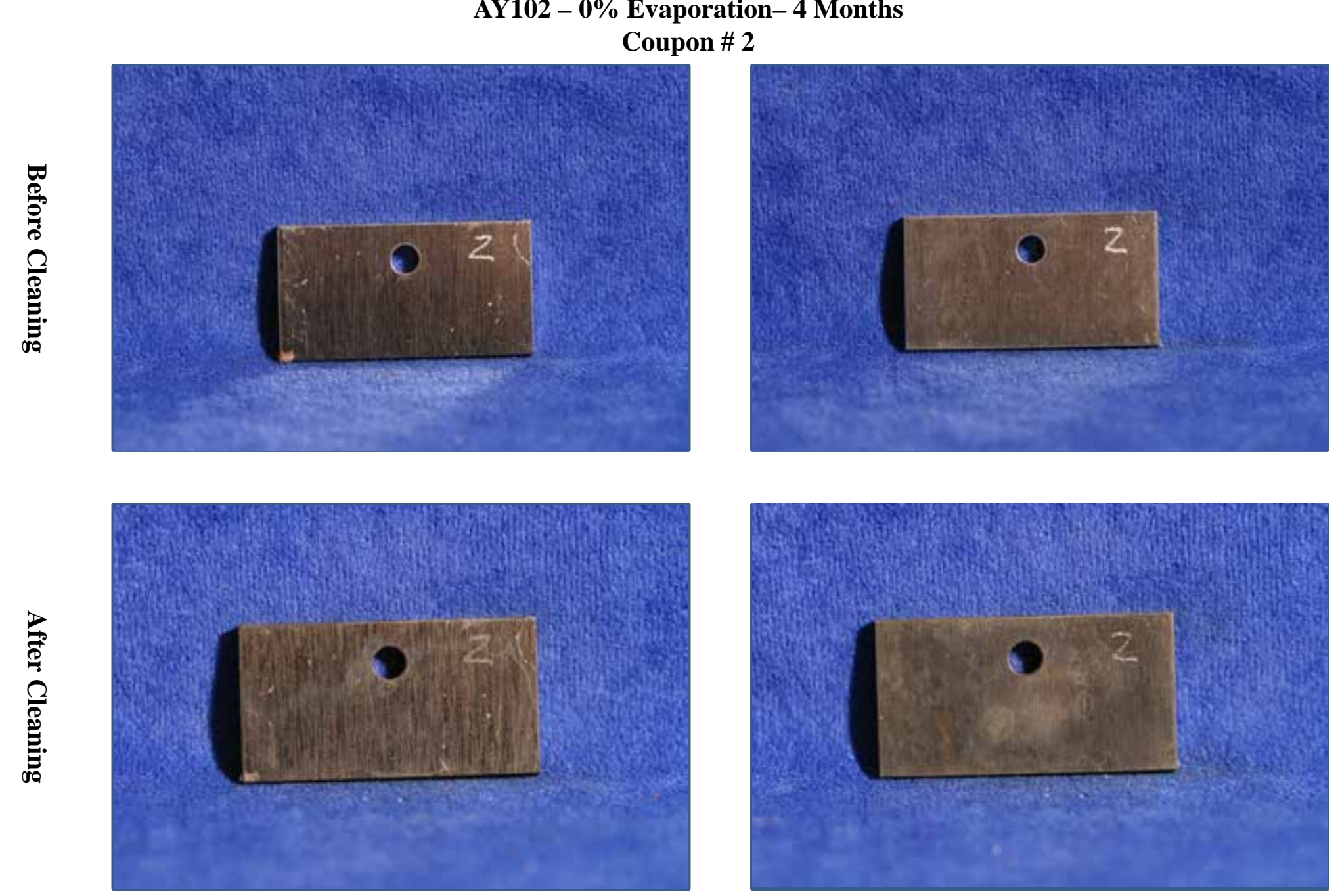


\section{Coupon \# 3}
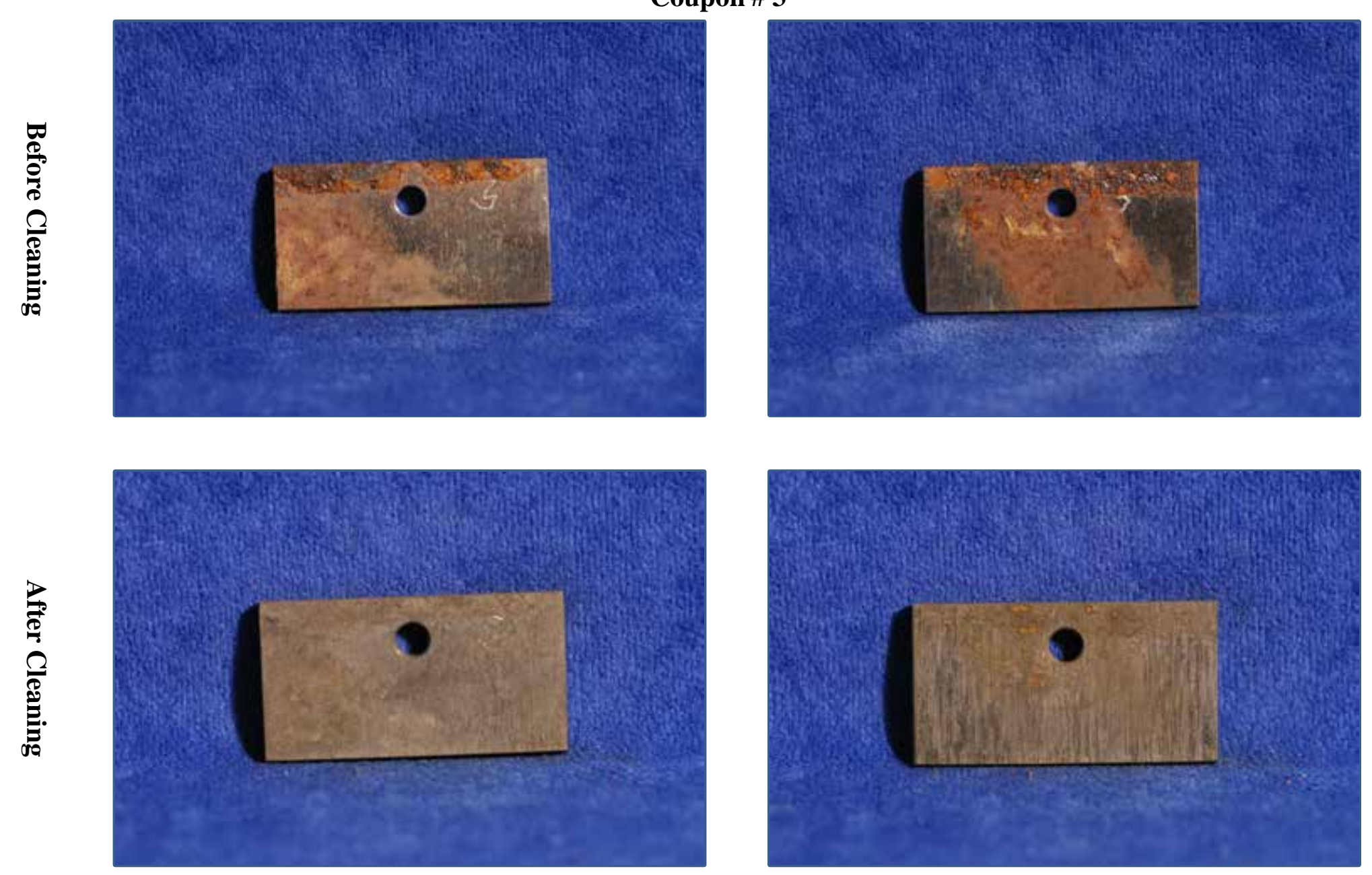
SY102 High Nitrate - 0\% Evaporation - 2 Months

Coupon \# 4
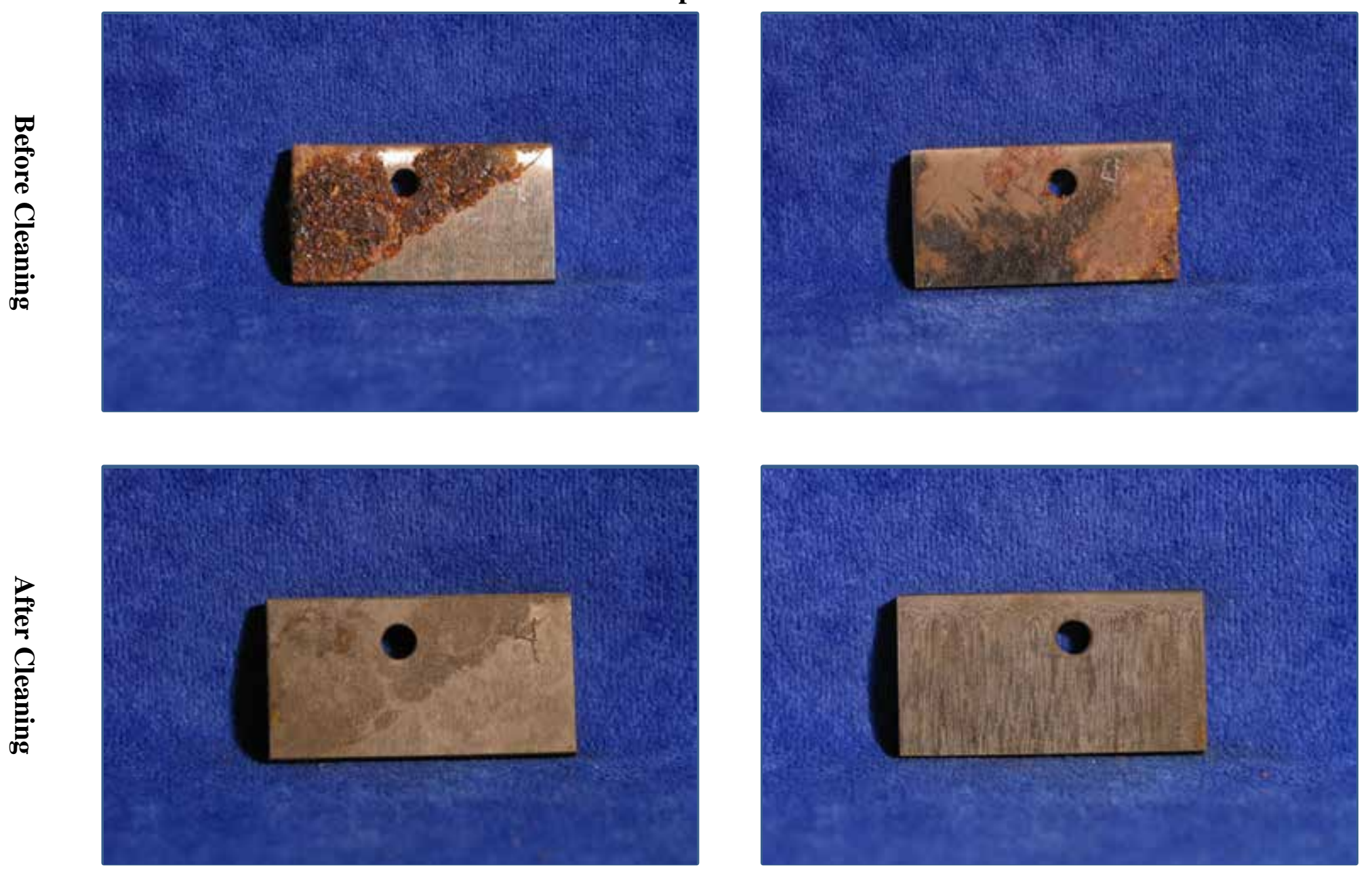
SY102 High Nitrate - 0\% Evaporation - 4 Months

Coupon \# 1
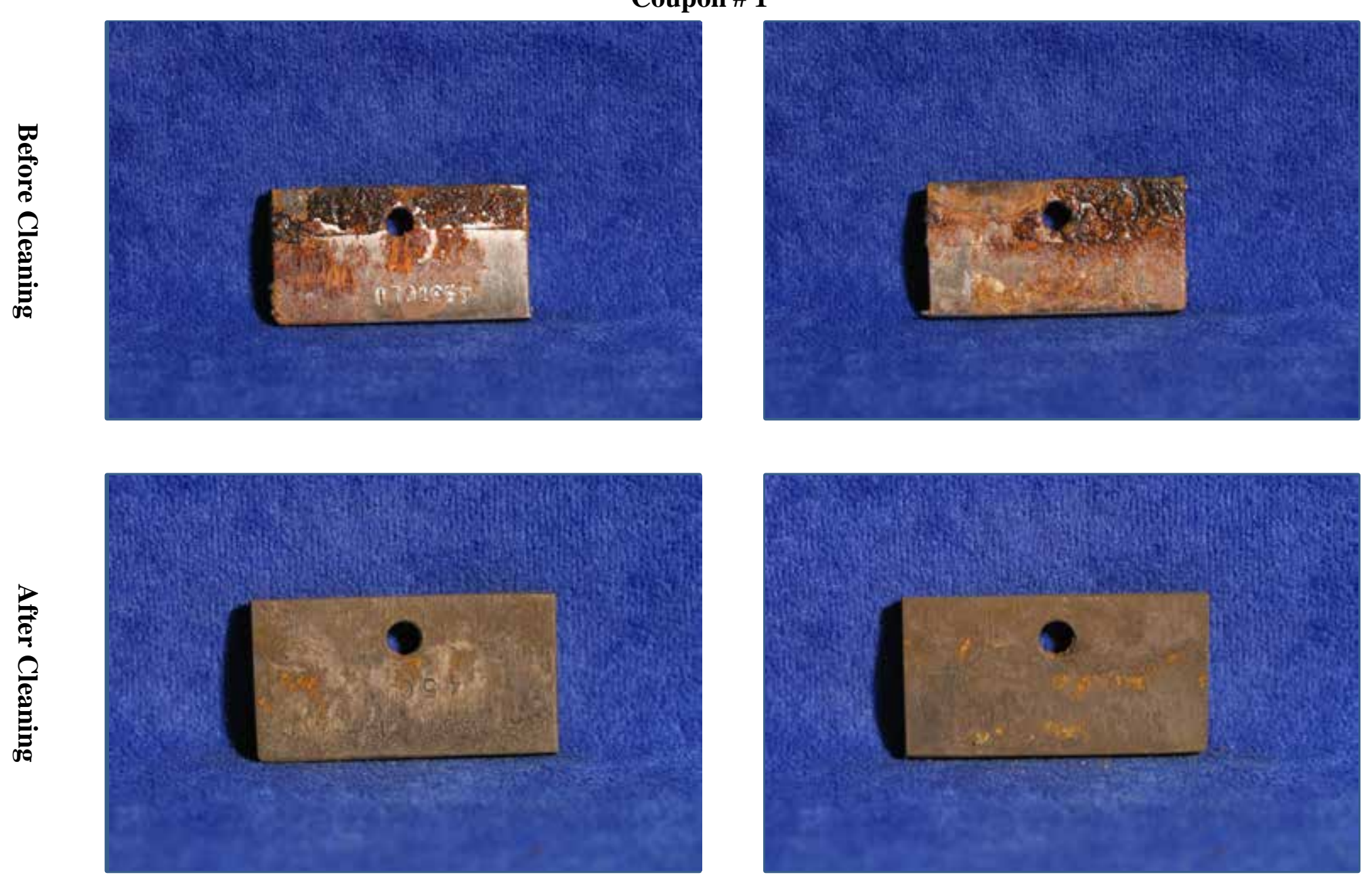
SY102 High Nitrate - 0\% Evaporation - 4 Months

Coupon \# 2
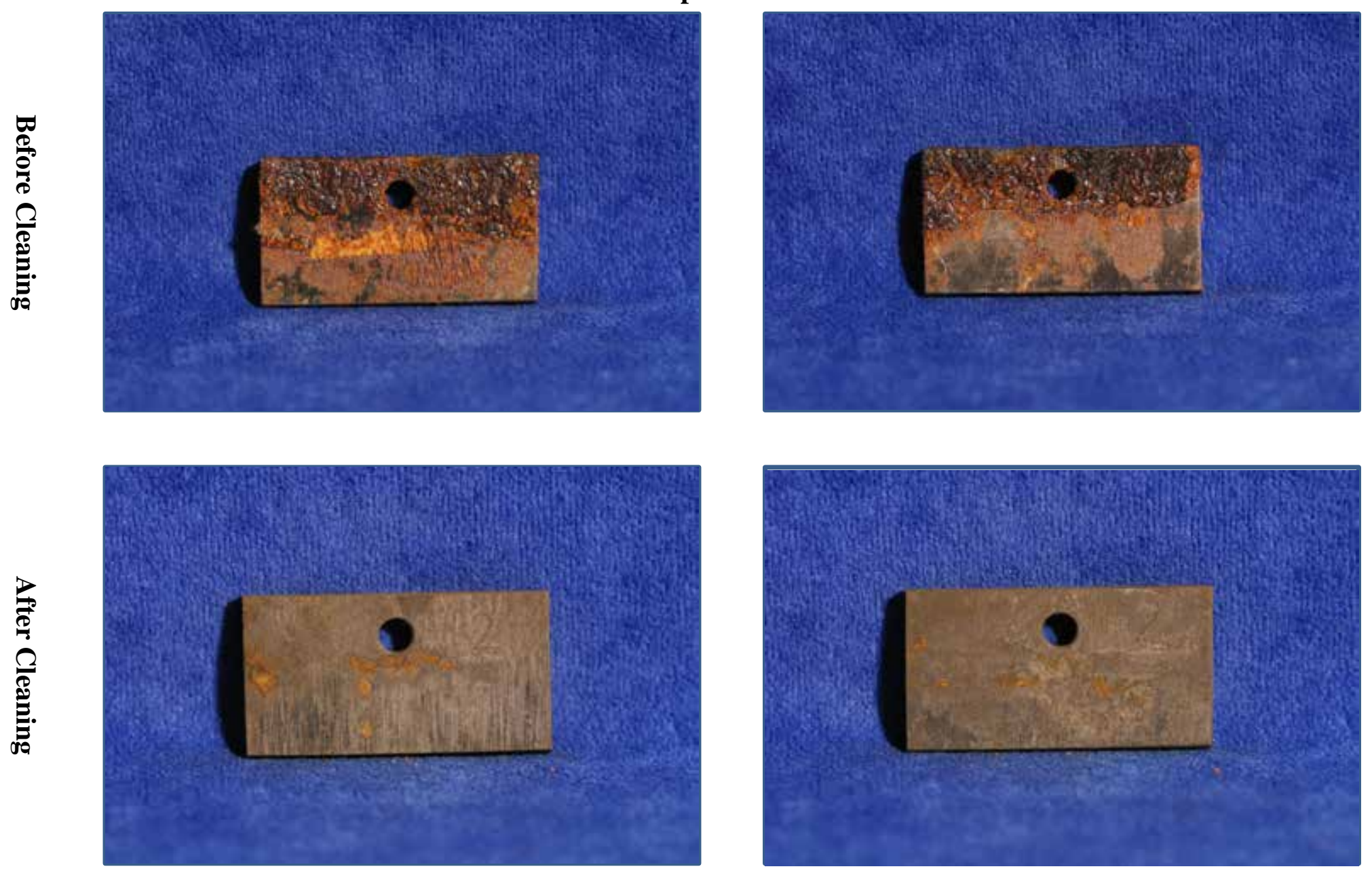
AY101 Segment 8 - 0\% Evaporation - 2 Months

Coupon \# 1
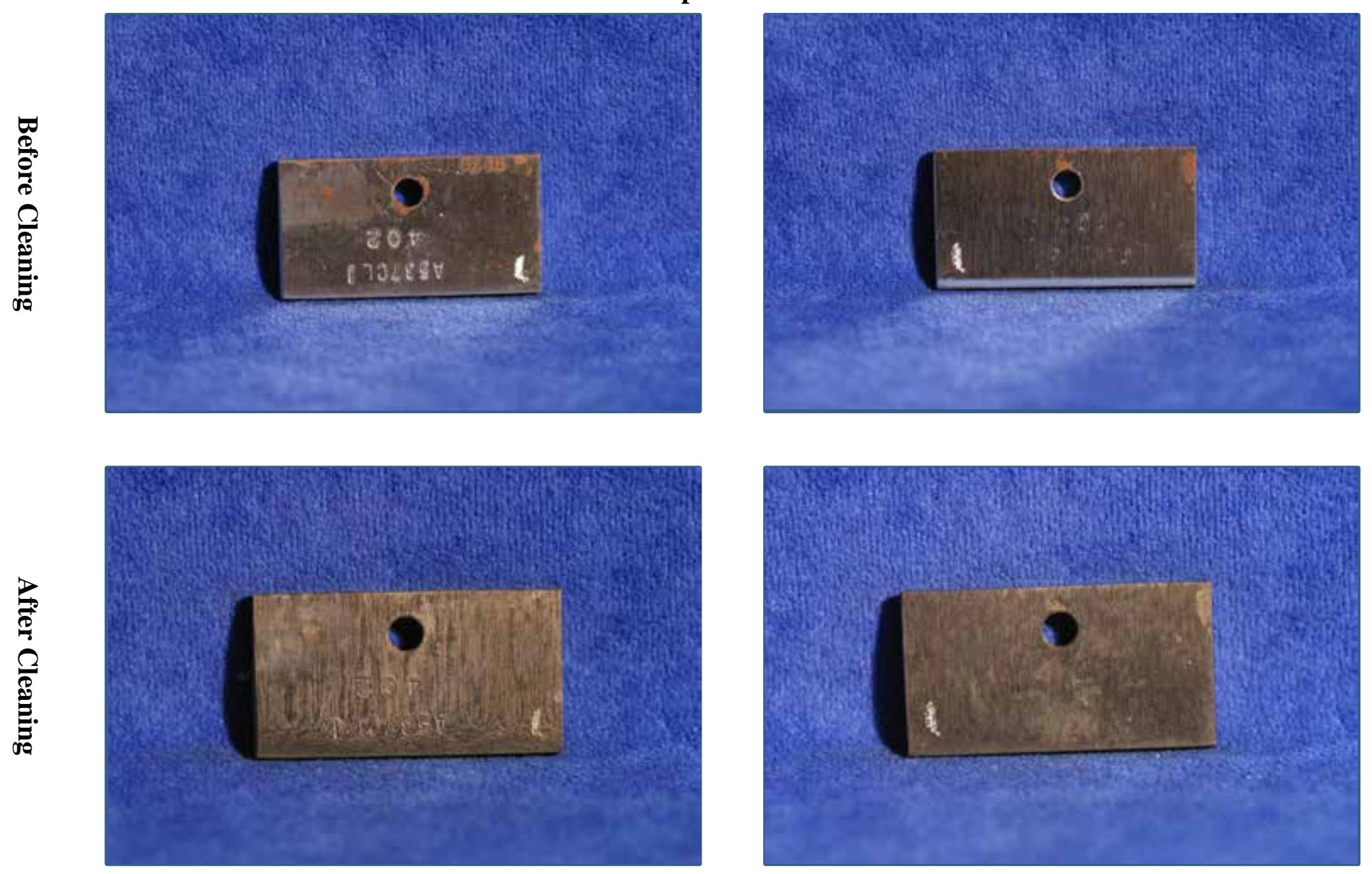
AY101 Segment 8 - 0\% Evaporation - 2 Months

Coupon \# 3
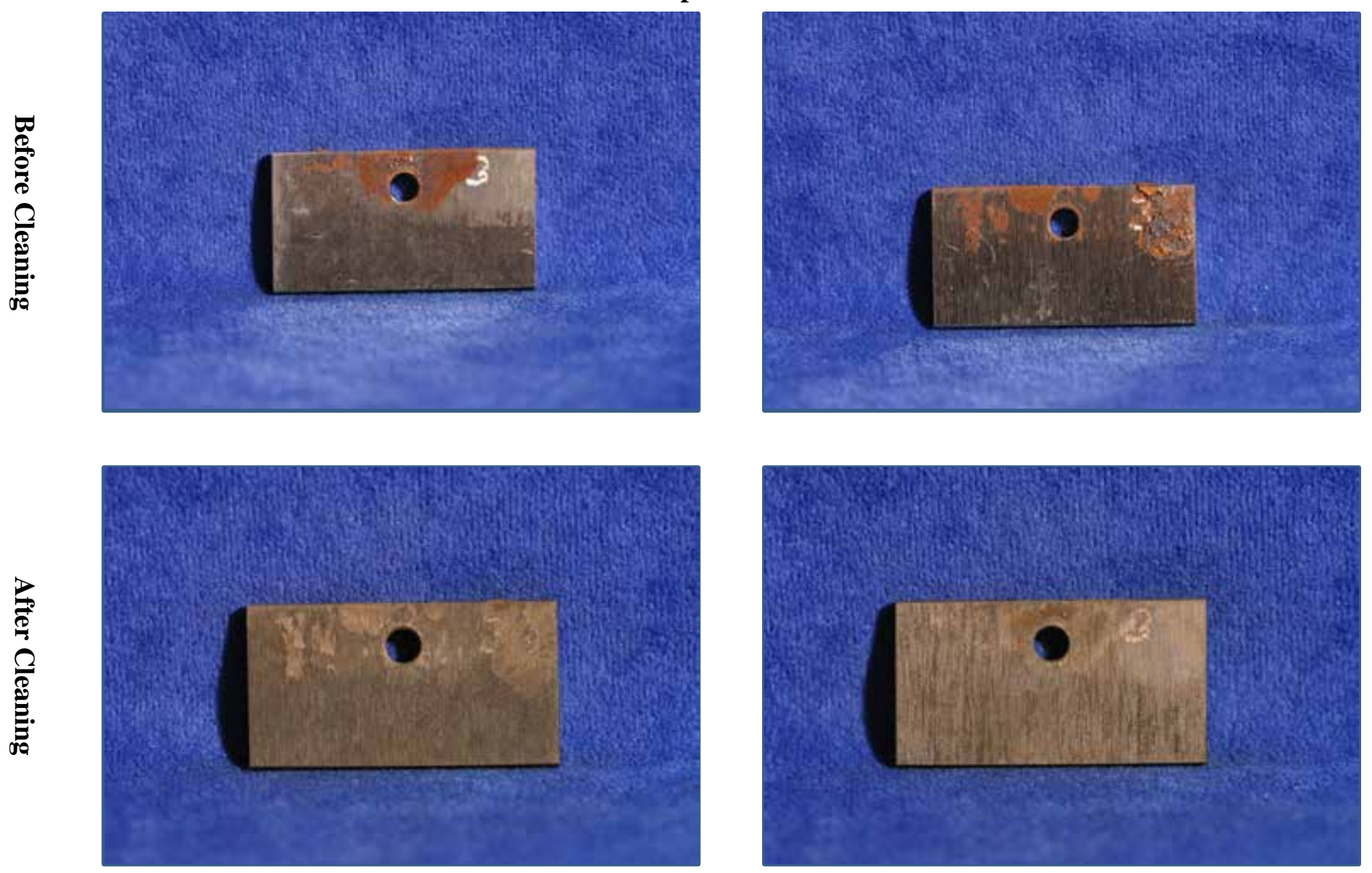
AY101 Segment 8 - 0\% Evaporation - 4 Months

Coupon \# 2
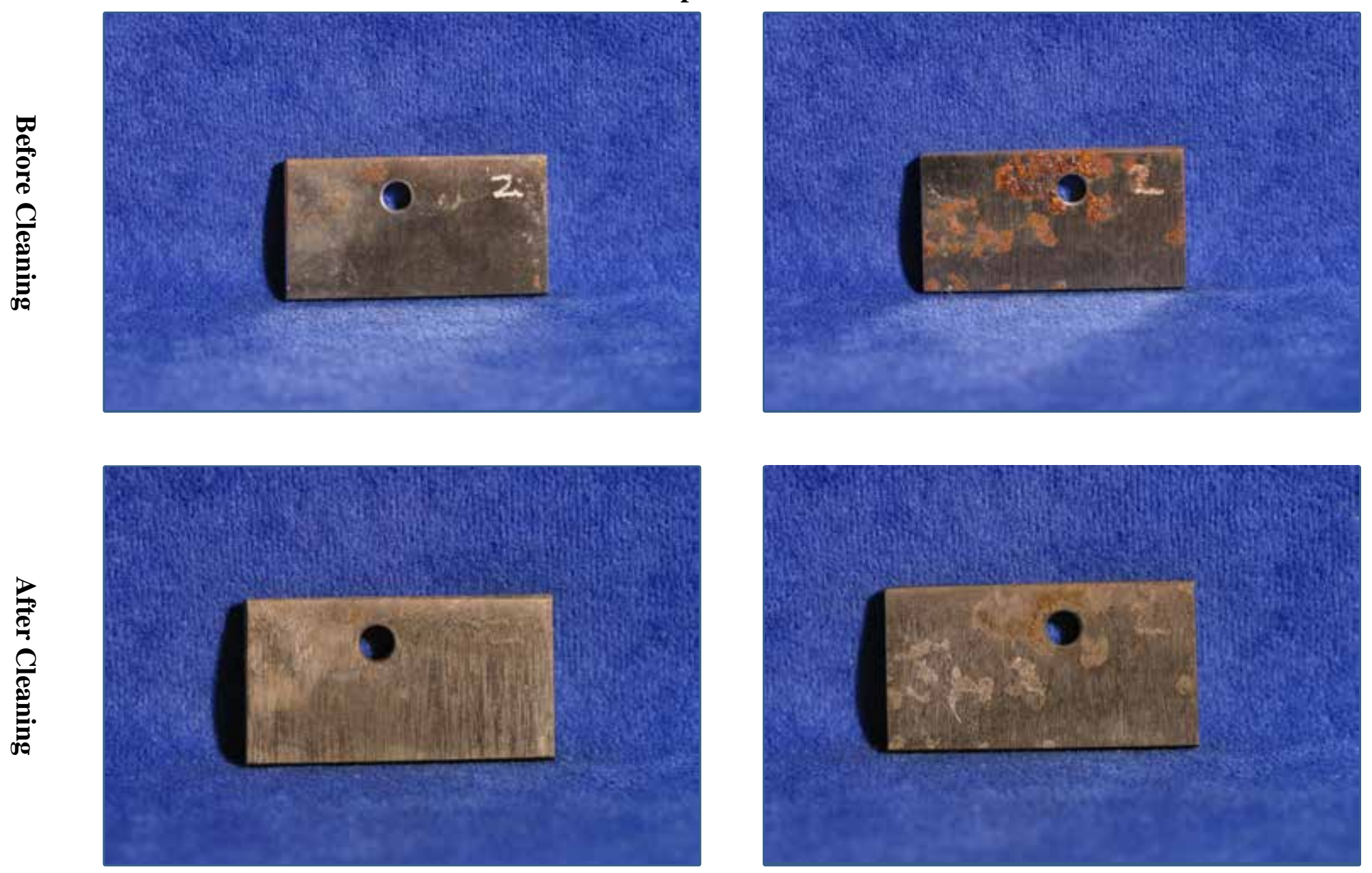
AY101 Segment 8 - 0\% Evaporation - 4 Months

Coupon \# 4
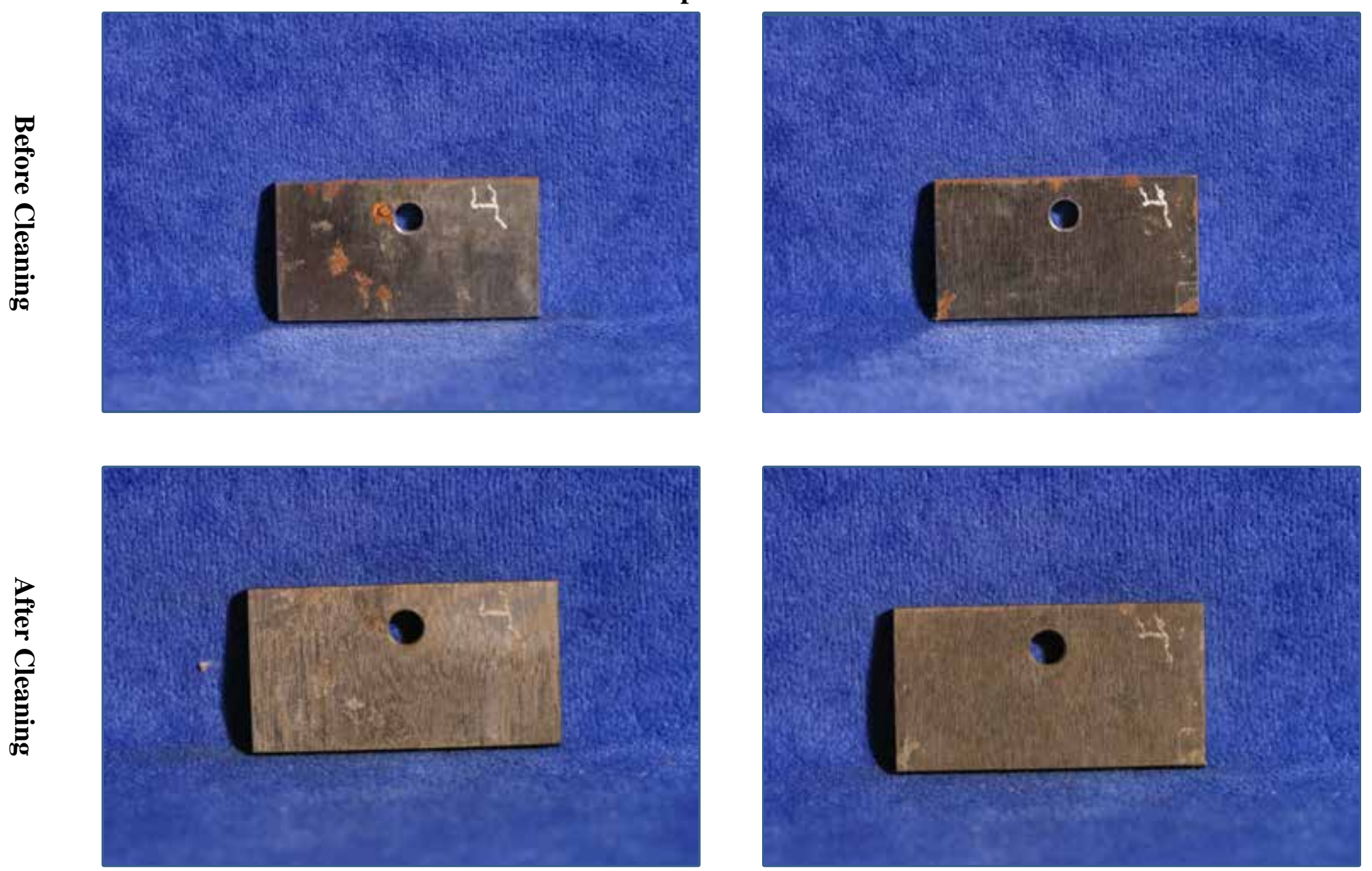
Visual Observations and Pit Measurements of Coupons*

$$
\text { AN102 - 0\% Evaporation }
$$

\begin{tabular}{|c|c|c|c|c|c|}
\hline Time (mo.) Coupon \# & Depth (mils) & Diameter (mils) & Depth/Diameter & \multicolumn{2}{|c|}{ Qualitative Density Estimate } \\
\hline 2 & 1 & NA & NA & NA & Surface is clean. \\
\hline & 2 & NA & NA & NA & Surface is clean \\
\hline 4 & 3 & NA & NA & NA & Surface is clean \\
\hline
\end{tabular}

* NA - no pitting observed 


\section{Visual Observations and Pit Measurements of Coupons*}

\section{AY101 - Segment 3 - 0\% Evaporation}

\begin{tabular}{|c|c|c|c|c|c|}
\hline Time (mo.) & Coupon \# & Depth (mils) & Diameter (mils) & Depth/Diameter & Qualitative Density Estimate \\
\hline \multirow{10}{*}{2} & \multirow{5}{*}{3} & 2.3 & 4.6 & 0.50 & \multirow{5}{*}{$\begin{array}{l}\text { Distinct LAI. Attack goes } \\
\text { above LAI. Limited attack } \\
\text { beneath LAI. }\end{array}$} \\
\hline & & 2.6 & 11.6 & 0.22 & \\
\hline & & 3 & 6.6 & 0.45 & \\
\hline & & 3.2 & 6.2 & 0.52 & \\
\hline & & 2.5 & 6.4 & 0.39 & \\
\hline & \multirow{5}{*}{4} & 4.2 & 12 & 0.35 & \multirow{5}{*}{$\begin{array}{l}\text { Distinct LAI. Attack goes } \\
\text { above LAI. Limited attack } \\
\text { beneath LAI. }\end{array}$} \\
\hline & & 2.4 & 8.8 & 0.27 & \\
\hline & & 1.9 & NA & NA & \\
\hline & & 3.9 & 11.8 & 0.33 & \\
\hline & & 3.2 & 13 & 0.25 & \\
\hline \multirow{10}{*}{4} & \multirow{5}{*}{1} & 3.4 & 7.7 & 0.44 & \multirow{5}{*}{$\begin{array}{l}\text { Distinct LAI. Attack goes } \\
\text { above LAI. Limited attack } \\
\text { beneath LAI. }\end{array}$} \\
\hline & & 2.8 & 6.9 & 0.41 & \\
\hline & & 2.1 & 14.4 & 0.15 & \\
\hline & & 2.5 & 7.3 & 0.34 & \\
\hline & & 2.5 & 5.6 & 0.45 & \\
\hline & \multirow{5}{*}{2} & 2.6 & 11.7 & 0.22 & \multirow{5}{*}{$\begin{array}{l}\text { Distinct LAI. Attack goes } \\
\text { above LAI. Limited attack } \\
\text { beneath LAI. }\end{array}$} \\
\hline & & 1.8 & NA & NA & \\
\hline & & 1.9 & 9.4 & 0.20 & \\
\hline & & 3 & 6.4 & 0.47 & \\
\hline & & 2.6 & 7.4 & 0.35 & \\
\hline
\end{tabular}

* NA - pits within locally attacked area and difficult to discern 
Visual Observations and Pit Measurements of Coupons*

\section{SY102 High Chloride- 0\% Evaporation}

\begin{tabular}{|c|c|c|c|c|c|}
\hline Time (mo.) & Coupon \# & Depth (mils) & Diameter (mils) & Depth/Diameter & Qualitative Density Estimate \\
\hline \multirow{10}{*}{2} & \multirow{5}{*}{1} & 2.5 & NA & NA & \multirow[t]{5}{*}{ Attack on less than $1 \%$ of area. } \\
\hline & & 2 & NA & NA & \\
\hline & & 1.3 & NA & NA & \\
\hline & & 1.3 & 3.6 & 0.36 & \\
\hline & & 2 & NA & NA & \\
\hline & \multirow{5}{*}{2} & 1.2 & 5.8 & 0.21 & \multirow[t]{5}{*}{ Attack on less than $1 \%$ of area. } \\
\hline & & 1.5 & 7.2 & 0.21 & \\
\hline & & 1.6 & 3.6 & 0.44 & \\
\hline & & 2.2 & NA & NA & \\
\hline & & 1.3 & 7.3 & 0.18 & \\
\hline \multirow{8}{*}{4} & \multirow{5}{*}{3} & 2.2 & 4.8 & 0.46 & \multirow[t]{5}{*}{ Attack on less than $1 \%$ of area. } \\
\hline & & 2.9 & 4.9 & 0.59 & \\
\hline & & 1.3 & 4.1 & 0.32 & \\
\hline & & 2 & 7.7 & 0.26 & \\
\hline & & 1.4 & 6 & 0.23 & \\
\hline & \multirow{3}{*}{4} & 1.7 & 3.8 & 0.45 & \multirow[t]{3}{*}{ Attack on less than $1 \%$ of area. } \\
\hline & & 1.8 & 3.9 & 0.46 & \\
\hline & & 1.1 & 3.2 & 0.34 & \\
\hline
\end{tabular}

* NA - pits within locally attacked area and difficult to discern 


\section{Visual Observations and Pit Measurements of Coupons*}

AY102 - 0\% Evaporation

\begin{tabular}{|c|c|c|c|c|c|}
\hline Time (mo.) Coupon \# & Depth (mils) & Diameter (mils) & Depth/Diameter & Qualitative Density Estimate \\
\hline 2 & 3 & NA & NA & NA & Surface is clean. \\
\hline & 4 & NA & NA & NA & Surface is clean. \\
\hline \multirow{2}{*}{4} & 1 & NA & NA & NA & Surface is clean. \\
\hline & 2 & NA & NA & NA & Surface is clean. \\
\hline
\end{tabular}

* NA - no pitting observed 
Visual Observations and Pit Measurements of Coupons*

SY102 High Nitrate - 0\% Evaporation

\begin{tabular}{|c|c|c|c|c|c|}
\hline Time (mo.) & Coupon \# & Depth (mils) & Diameter (mils) & Depth/Diameter & Qualitative Density Estimate \\
\hline \multirow{6}{*}{2} & 3 & NA & NA & NA & $\begin{array}{l}\text { Attack was general in nature } \\
\text { above LAI. Greater than } 90 \% \\
\text { of coupon below LAI. }\end{array}$ \\
\hline & \multirow{5}{*}{4} & 2.8 & 10.8 & 0.26 & \multirow{5}{*}{$\begin{array}{l}\text { Distinct LAI. Attack goes } \\
\text { above LAI. Limited attack } \\
\text { beneath LAI. }\end{array}$} \\
\hline & & 4.8 & 10.4 & 0.46 & \\
\hline & & 3.3 & 6.6 & 0.50 & \\
\hline & & 2.1 & 5.9 & 0.36 & \\
\hline & & 3.4 & 10.5 & 0.32 & \\
\hline \multirow{10}{*}{4} & \multirow{5}{*}{1} & 3.2 & NA & NA & \multirow{5}{*}{$\begin{array}{l}\text { Distinct LAI. Attack goes } \\
\text { above LAI. Limited attack } \\
\text { beneath LAI. }\end{array}$} \\
\hline & & 2.9 & 8.4 & 0.35 & \\
\hline & & 4.2 & 12.8 & 0.33 & \\
\hline & & 3.7 & 11.4 & 0.32 & \\
\hline & & 3.6 & 10.1 & 0.36 & \\
\hline & \multirow{5}{*}{2} & 2.7 & 10.9 & 0.25 & \multirow{5}{*}{$\begin{array}{l}\text { Distinct LAI. Attack goes } \\
\text { above LAI. Limited attack } \\
\text { beneath LAI. }\end{array}$} \\
\hline & & 1.7 & 5.2 & 0.33 & \\
\hline & & 2.9 & NA & NA & \\
\hline & & 2.7 & 4.4 & 0.61 & \\
\hline & & 2.6 & NA & NA & \\
\hline
\end{tabular}

* NA - pits within locally attacked area and difficult to discern 


\section{AY101 Segment 8 - $0 \%$ Evaporation}

\begin{tabular}{|c|c|c|c|c|c|}
\hline Time (mo.) & Coupon \# & Depth (mils) & Diameter (mils) & Depth/Diameter & Qualitative Density Estimate \\
\hline \multirow[b]{2}{*}{2} & 1 & NA & NA & NA & Surface is clean. \\
\hline & 3 & NA & NA & NA & $\begin{array}{l}\text { Light surface attack above LAI } \\
\text { in one area. }\end{array}$ \\
\hline \multirow{2}{*}{4} & 2 & NA & NA & NA & $\begin{array}{l}\text { Light surface attack above LAI } \\
\text { in one area. }\end{array}$ \\
\hline & 4 & NA & NA & NA & $\begin{array}{l}\text { Light surface attack above LAI } \\
\text { in one area. }\end{array}$ \\
\hline
\end{tabular}

* NA - no pitting observed 
SRNL-STI-2013-00743

Revision 0

\section{APPENDIX D}

\section{Ammonia Gas Coupon Test Data}


SY102 High Nitrate - 33\% Evaporation- 50 ppm $\mathrm{NH}_{3}$

2 Months - Coupon \# 519
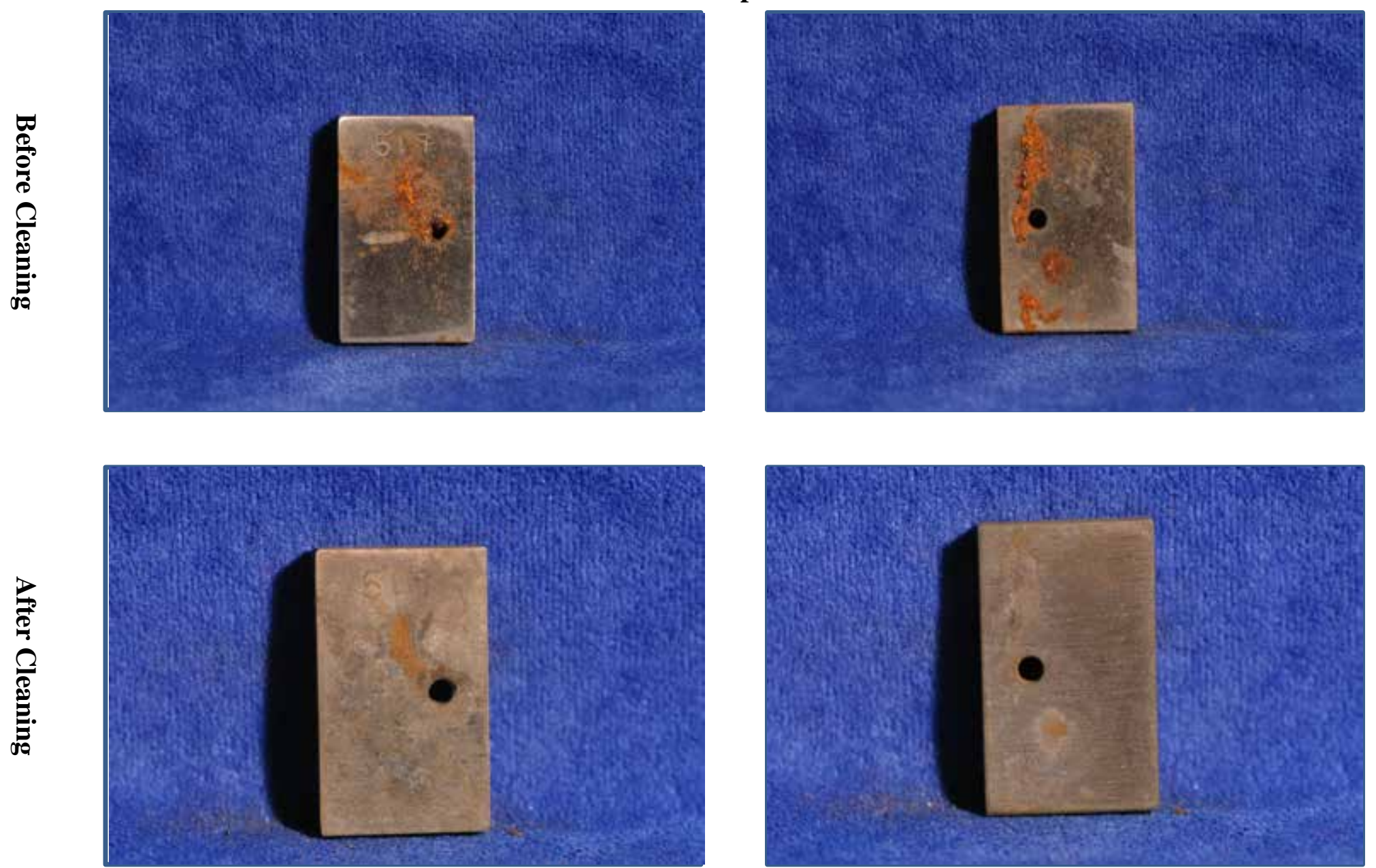
SY102 High Nitrate - 33\% Evaporation- 50 ppm $\mathrm{NH}_{3}$

2 Months - Coupon \# 521
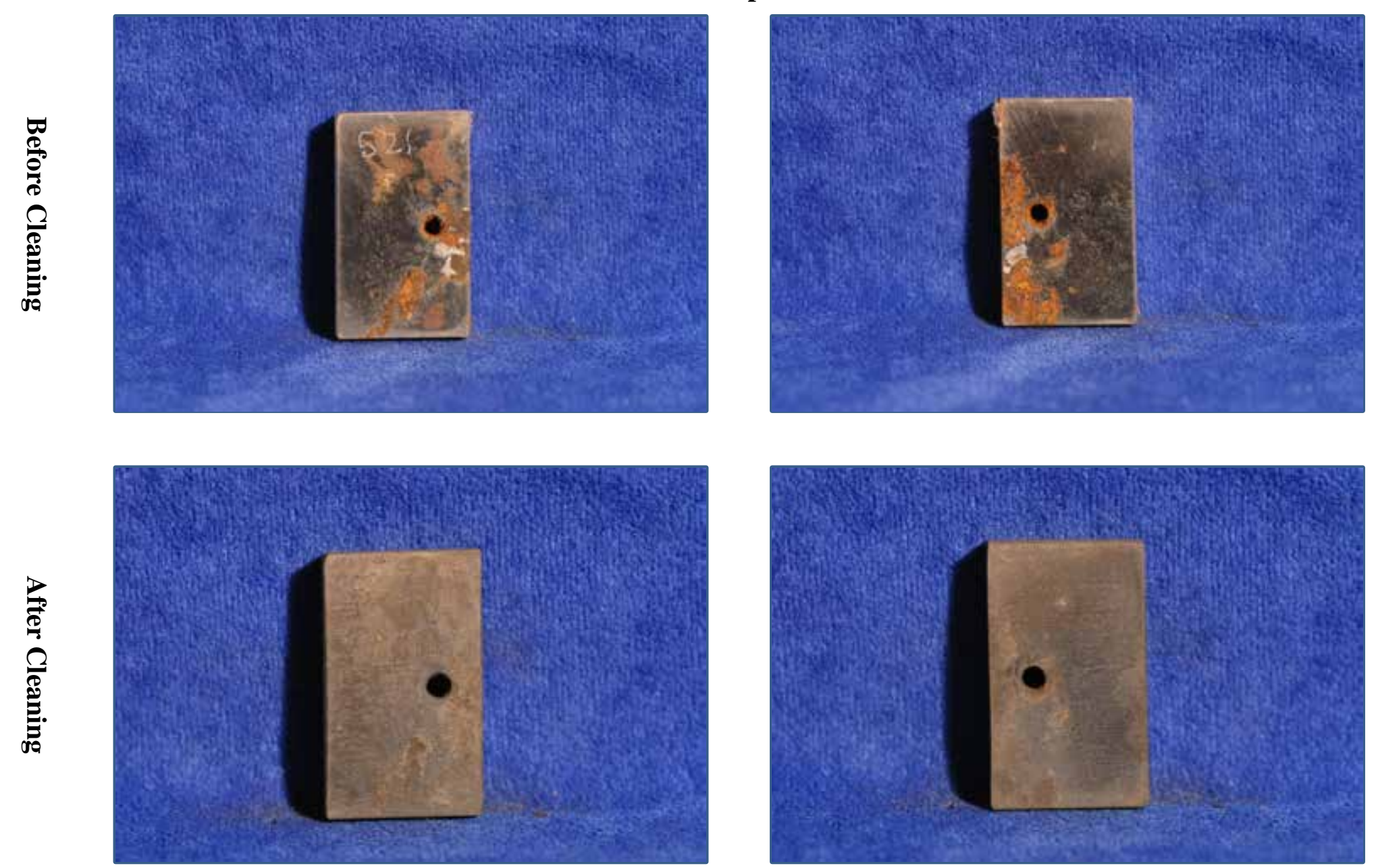
SRNL-STI-2013-00743

Revision 0

SY102 High Nitrate - 33\% Evaporation- 50 ppm $\mathrm{NH}_{3}$ 4 Months - Coupon \# 504
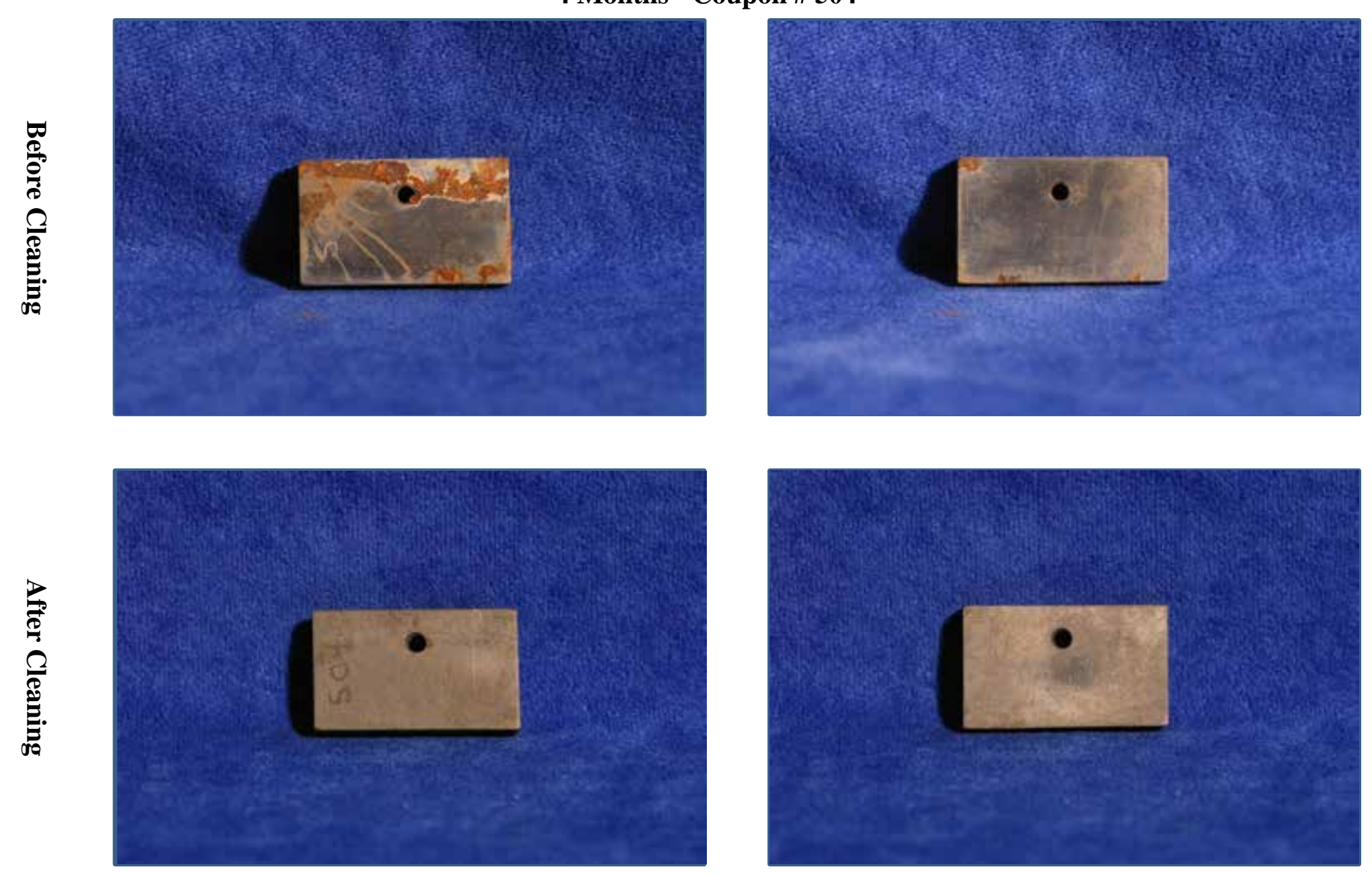
SY102 High Nitrate - 33\% Evaporation- 50 ppm $\mathrm{NH}_{3}$

4 Months - Coupon \# 516
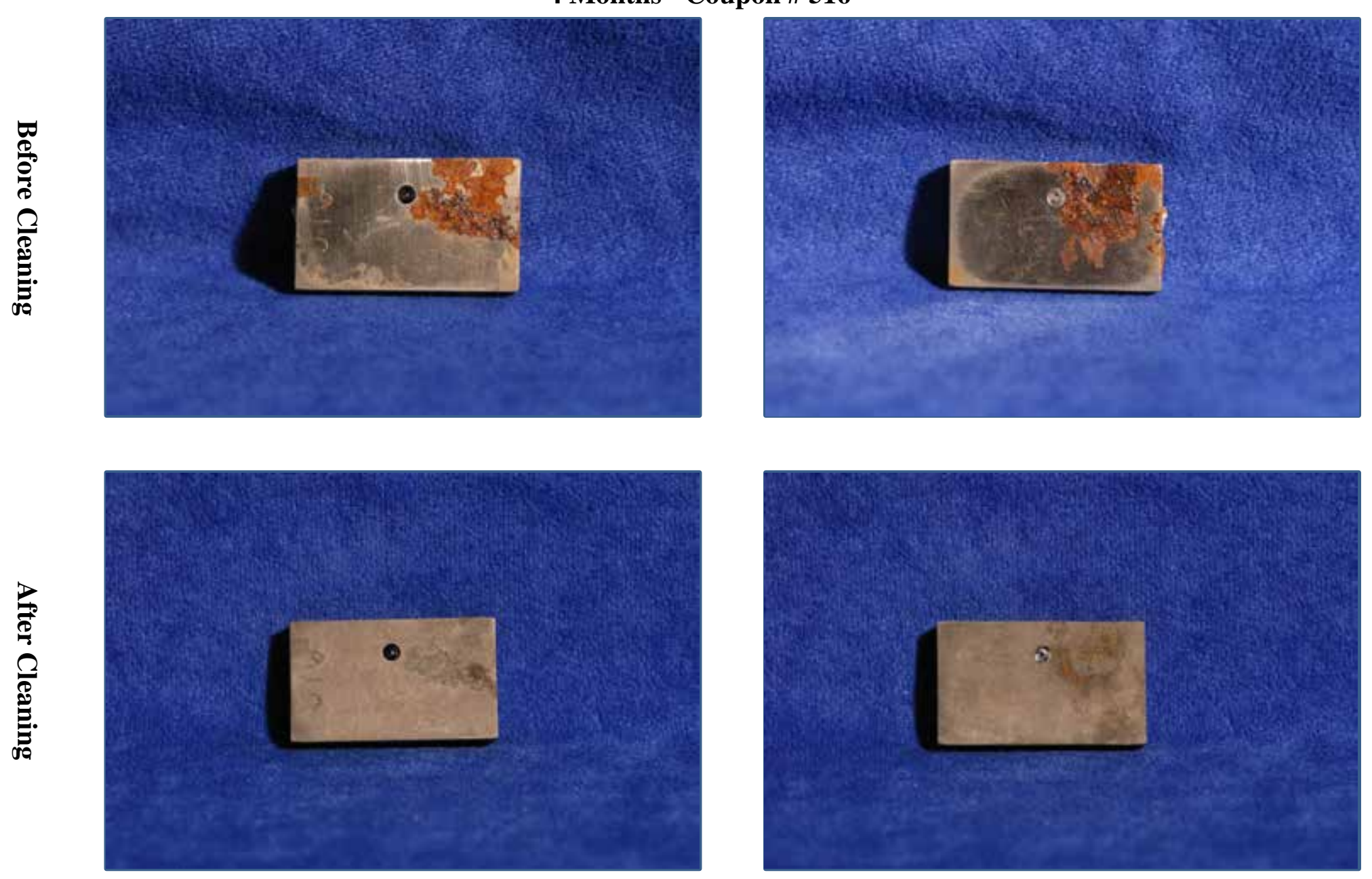

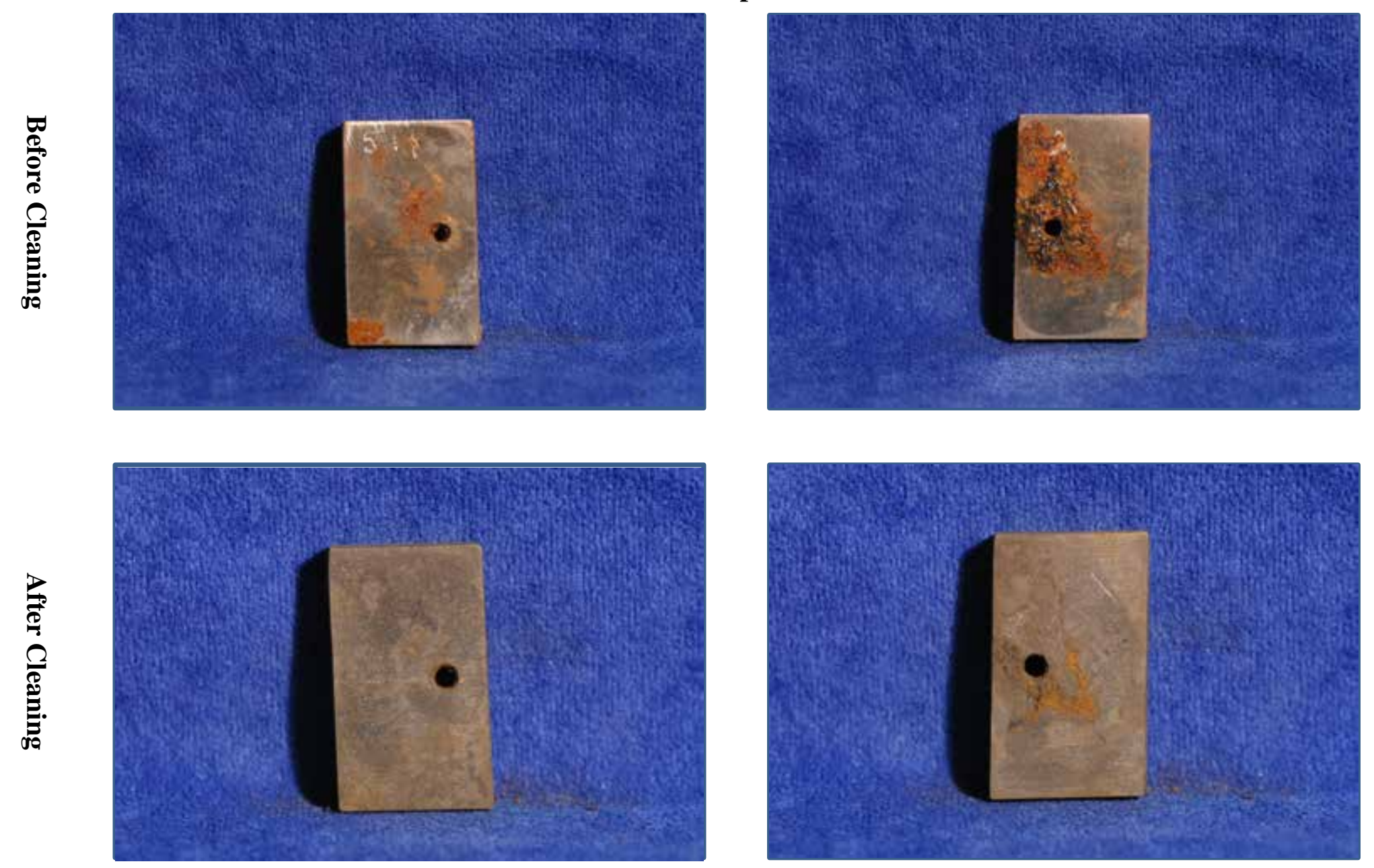
SY102 High Nitrate - 33\% Evaporation- 550 ppm $\mathrm{NH}_{3}$
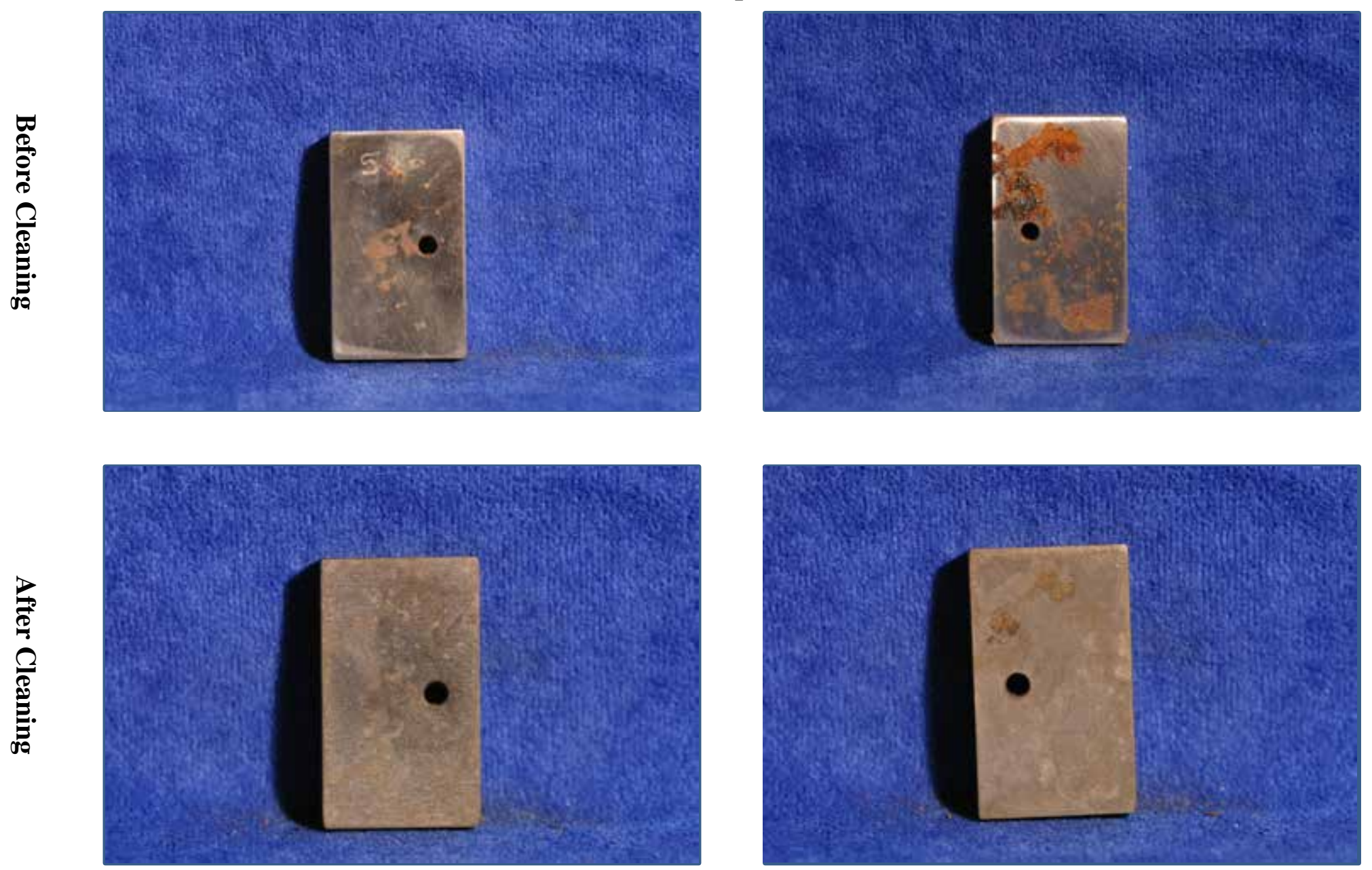
SY102 High Nitrate - 33\% Evaporation- 550 ppm $\mathrm{NH}_{3}$
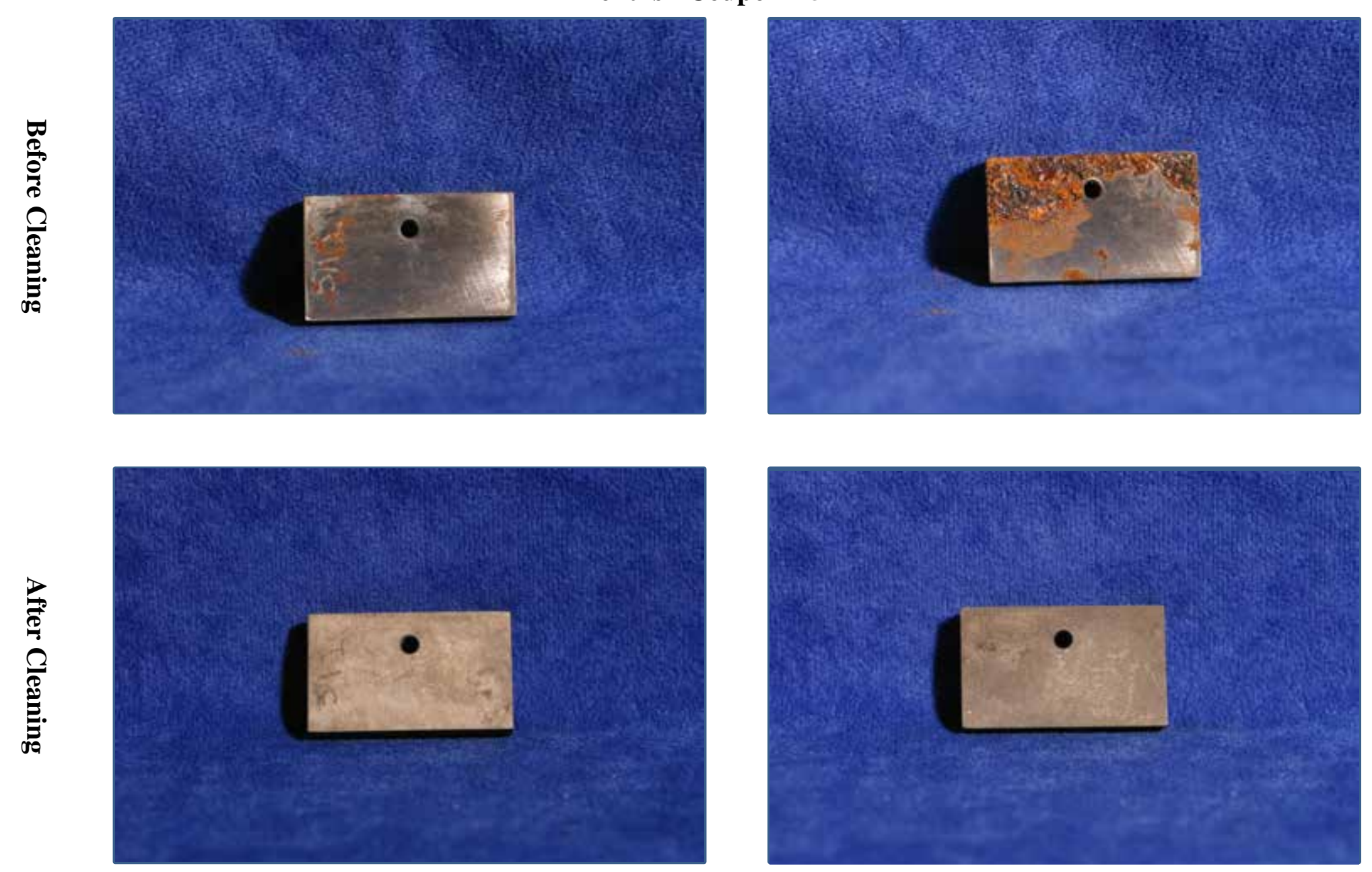
SRNL-STI-2013-00743

Revision 0

SY102 High Nitrate - 33\% Evaporation- 550 ppm $\mathrm{NH}_{3}$ 4 Months - Coupon \# 518
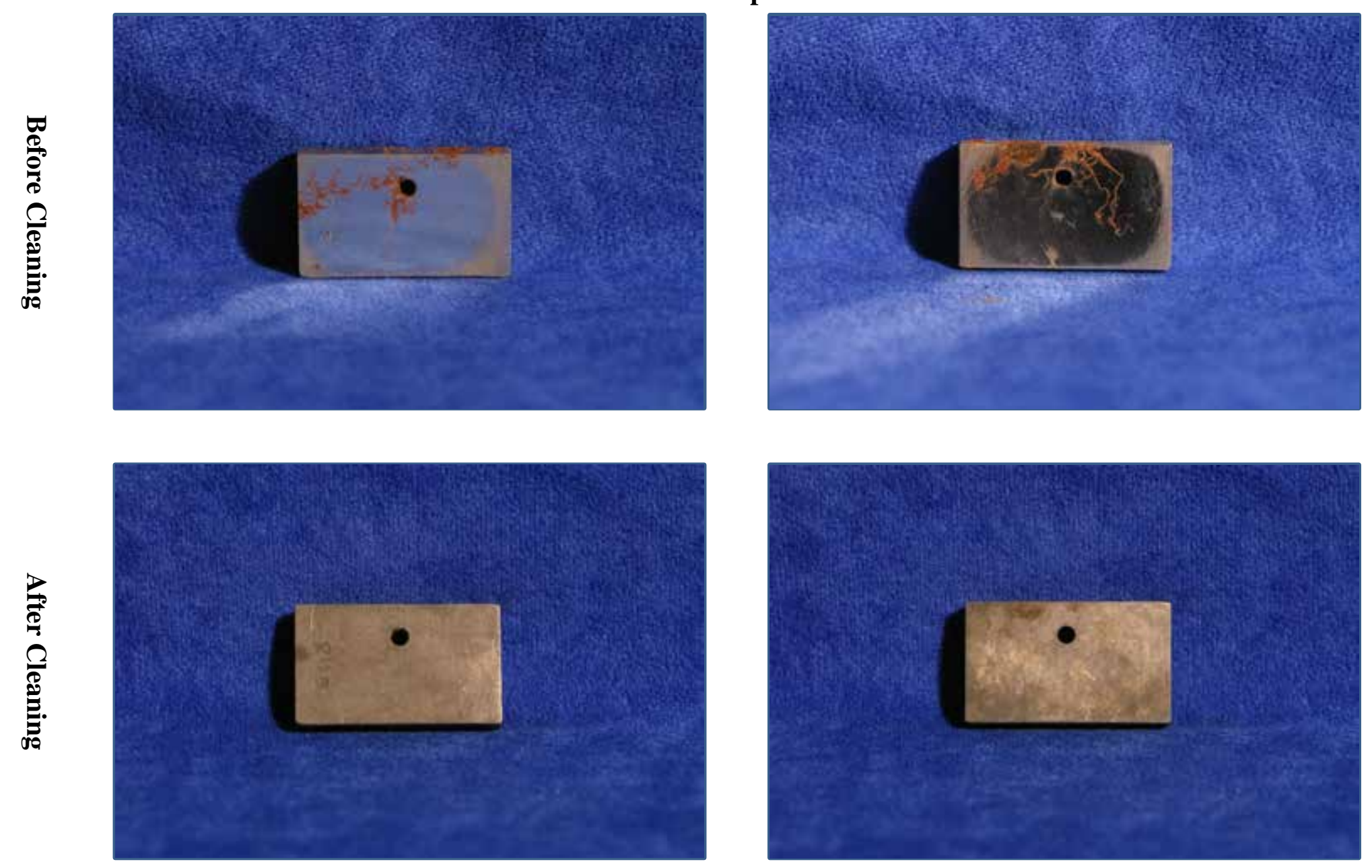


\section{Visual Observations and Pit Measurements of Coupons*}

SY102 High Nitrate - 33\% Evaporation- 50 ppm $\mathrm{NH}_{3}$

\begin{tabular}{|c|c|c|c|c|c|}
\hline Time (mo.) & Coupon \# & Depth (mils) & Diameter (mils) & Depth/Diameter & Qualitative Density Estimate \\
\hline \multirow{2}{*}{2} & 519 & NA & NA & NA & $\begin{array}{l}\text { No Pitting. Attack on less than } \\
10 \% \text { of area. }\end{array}$ \\
\hline & 521 & NA & NA & NA & $\begin{array}{l}\text { No Pitting. Attack on less than } \\
10 \% \text { of area. }\end{array}$ \\
\hline & 504 & NA & NA & NA & No LAI. No pitting. \\
\hline & 516 & NA & NA & NA & No LAI. No pitting. \\
\hline
\end{tabular}

* NA - no pitting observed 
Visual Observations and Pit Measurements of Coupons* SY102 High Nitrate - 33\% Evaporation- 550 ppm $\mathrm{NH}_{3}$

\begin{tabular}{|c|c|c|c|c|c|}
\hline Time (mo.) & Coupon \# & Depth (mils) & Diameter (mils) & Depth/Diameter & Qualitative Density Estimate \\
\hline \multirow{2}{*}{2} & 511 & NA & NA & NA & $\begin{array}{l}\text { No Pitting. Attack on less than } \\
10 \% \text { of area. }\end{array}$ \\
\hline & 520 & NA & NA & NA & $\begin{array}{l}\text { No Pitting. Attack on less than } \\
10 \% \text { of area. }\end{array}$ \\
\hline \multirow{2}{*}{4} & 512 & NA & NA & NA & $\begin{array}{l}\text { No LAI. No pitting. Small } \\
\text { area of surface attack at top of } \\
\text { coupon. }\end{array}$ \\
\hline & 518 & NA & NA & NA & $\begin{array}{l}\text { No LAI. No pitting. Small } \\
\text { area of surface attack at top of } \\
\text { coupon. }\end{array}$ \\
\hline
\end{tabular}

* NA - no pitting observed 